UNIVERSIDADE DE BRASÍLIA

FACULDADE DE AGRONOMIA E MEDICINA VETERINÁRIA PROGRAMA DE PÓS-GRADUAÇ̃̃o EM AGRONOMIA

CARACTERIZAÇÃO AGRONÔMICA E FISÍCO-QUÍMICA DE PROGÊNIES DE MARACUJAZEIRO AZEDO (Passiflora edulis Sims) NO DISTRITO FEDERAL

ISADORA NOGUEIRA

DISSERTAÇÃO DE MESTRADO EM AGRONOMIA

BRASÍLIA/DF

FEVEREIRO/2016 
UNIVERSIDADE DE BRASÍLIA

FACULDADE DE AGRONOMIA E MEDICINA VETERINÁRIA

PROGRAMA DE PÓS-GRADUAÇÃO EM AGRONOMIA

\title{
CARACTERIZAÇÃO AGRONÔMICA E FISÍCO-QUÍMICA DE PROGÊNIES DE MARACUJAZEIRO AZEDO (Passiflora edulis Sims) NO DISTRITO FEDERAL
}

\author{
ISADORA NOGUEIRA
}

Orientador: Professor Doutor José Ricardo Peixoto

Có-orientador: Professor Doutor Fábio Gelape Faleiro

DISSERTAÇÃO DE MESTRADO EM AGRONOMIA

BRASÍLIA/DF

FEVEREIRO/2016 


\title{
CARACTERIZAÇÃO AGRONÔMICA E FISÍCO-QUÍMICA DE PROGÊNIES DE MARACUJAZEIRO AZEDO (Passiflora edulis Sims) NO DISTRITO FEDERAL
}

\author{
ISADORA NOGUEIRA
}

DisSertaÇão de MESTRAdo SUBMETIDA À FACULDADE DE AGRONOMIA E MEDICINA VETERINÁRIA DA UNIVERSIDADE DE BRASÍLIA - UnB, COMO PARTE DOS REQUISITOS NECESSÁRIOS À OBTENÇÃO DO GRAU DE MESTRE EM AGRONOMIA.

APROVADO POR:

JOSÉ RICARDO PEIXOTO, Doutor (Universidade de Brasília - FAV)

Orientador, CPF: 354.356.236-34

peixoto@unb.br

MÁRCIO DE CARVALHO PIRES, Doutor (Universidade de Brasília - FAV)

Examinador Interno, CPF: 844.256.601-53

mcpires@unb.br

MICHELLE SOUZA VILELA, Doutora, (Universidade de Brasília - FAV)

Examinador Externo, CPF: 919.623.401-63

michellevilelaunb@gmail.com 


\section{FICHA CATALOGRÁFICA}

Nogueira, Isadora

Caracterização agronômica e fisíco-química de progênies de maracujazeiro azedo (Passiflora edulis Sims) no Distrito Federal / Isadora Nogueira; Orientação: José Ricardo Peixoto. Brasília, 2016. 110 p.

Dissertação de Mestrado (M) - Universidade de Brasília / Faculdade de Agronomia e Medicina Veterinária, 2016.

1. Passiflora eduli Sims. 2.Produtividade. 3.Resistência à doenças. 4. Melhoramento.

\section{REFERÊNCIA BIBLIOGRÁFICA}

NOGUEIRA, I. Caracterização agronômica e fisíco-química de progênies de maracujazeiro azedo (Passiflora edulis Sims) no Distrito Federal. Faculdade de Agronomia e Medicina Veterinária, Universidade de Brasília-Brasília, 2016; 110 p. Dissertação de Mestrado.

\section{CESSÃO DE DIREITOS}

NOME DO AUTOR: Isadora Nogueira

TÍTULO DA TESE DE DOUTORADO: Caracterização agronômica e fisíco-química de progênies de maracujazeiro azedo (Passiflora edulis Sims) no Distrito Federal. GRAU:

MESTRE. ANO: 2016

É concedida à Universidade de Brasília permissão para reproduzir cópias desta dissertação de mestrado e para emprestar ou vender tais cópias somente para propósitos acadêmicos e científicos. $\mathrm{O}$ autor reserva os outros direitos de publicação e nenhuma parte desta dissertação de mestrado pode ser reproduzida sem a autorização por escrito do autor.

Isadora Nogueira

CPF: 035500073-37

Endereço: Rua Santa Luzia, no 237 . Centro. Formosa-GO

Tel: (61) $36313736 \quad$ E-mail: i.nogueiraa@gmail.com 
Aos meus pais, Cléa e Otacílio, e meus irmãos João e Pedro, pela confiança e apoio. Ao Murilo pela compreensão e companheirismo.

Dedico. 


\section{AGRADECIMENTOS}

A Deus, por todos os caminhos e oportunidades que me fez passar para completar mais uma etapa da minha vida.

Aos meus amados pais, Cléa e Otacílio, por toda ajuda, estímulo, paciência e amor durante todas as etapas da minha vida até agora, que apesar de não fazerem ideia do que eu faço sempre me apoiaram e me aplaudiram com muito orgulho.

Ao meu irmão João, que não mediu esforços para a minha chegada até aqui, por todo carinho e cuidado que sempre teve comigo.

Ao meu irmão Pedro, por ser meu exemplo de profissional, por me ensinar a ser forte e me apoiar.

A você Murilo, por fazer parte da minha vida, por compartilhar todas as alegrias e tristezas. Obrigada por todo companheirismo, compreensão, respeito, cumplicidade e amor.

Aos meus queridos sogros, Aline e Fred, minha segunda família, pelas orações, carinho e apoio.

Ao Professor José Ricardo Peixoto, por todos os ensinamentos desde a graduação, pela amizade, paciência, motivação, por ser um exemplo de dedicação profissional.

A Professora Michelle Souza Vilela, pela imensurável ajuda, amizade, ensinamentos, paciência e compreensão.

Ao Dr. Fábio Faleiro pelas contribuições no trabalho, ideias inovadoras e incentivo.

Aos técnicos Cesinha, Are e Márcio, por todas as exceções na greve, amizade e risadas.

A minha grande companheira de trabalho e amiga Anne Costa, por tornar a rotina mais agradável e me fazer crescer como pessoa e profissional.

A Maryanne da Costa Pereira, meu anjo da guarda, pela ajuda psicológica, apoio e amizade incondicional.

Aos meus colegas de curso, Daiane, Hanna, Ellen, Paulo, Wallace, Eric, Tamara, Fabríccio, Vinicius e Heloisa, que tornaram esta jornada mais agradável.

A todos os professores e a secretaria do departamento de agronomia que participaram do meu processo de formação.

A todas as pessoas que direta ou indiretamente contribuíram para o desenvolvimento deste trabalho.

Ao Conselho Nacional de Desenvolvimento Científico e Tecnológico - CNPq, pelos recursos financeiros destinados à realização do trabalho. 


\section{SUMÁRIO}

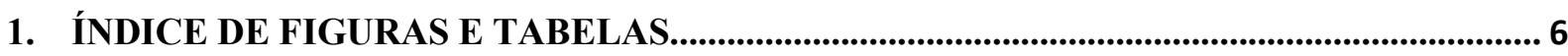

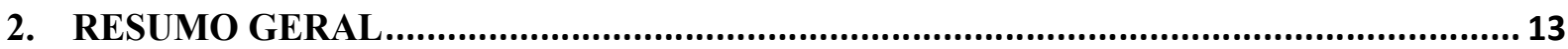

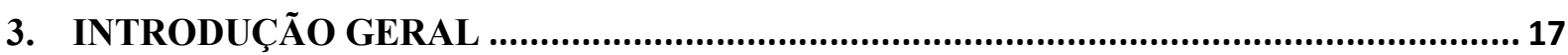

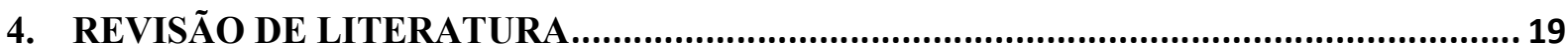

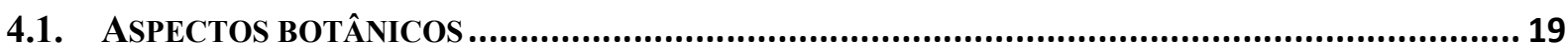

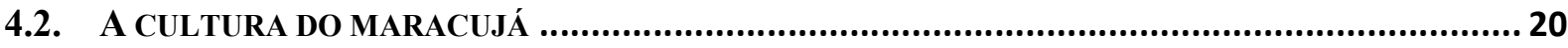

4.3. MELHORAMENTO DO MARACUJAZEIRO AZEDO VISANDO A RESISTÊNCIA À DOENÇAS ......... 21

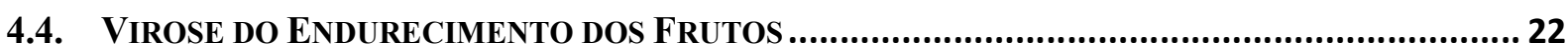

4.5. BACTERIOSE

4.6. ASPECTOS RELACIONADOS A PRODUTIVIDADE E QUALIDADE DOS FRUTOS ....................... 26

4.7. CARACTERÍSTICAS FÍSICO-QUÍMICAS DOS FRUTOS NA PÓS-COLHEITA.............................. 27

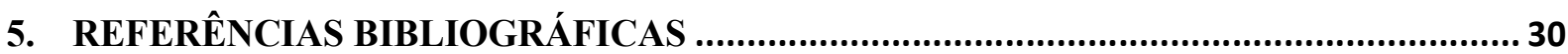

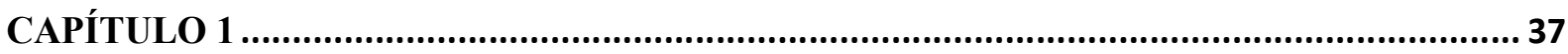

AVALIAÇÃO DA SEVERIDADE E INCIDÊNCIA DE XANTHOMONAS AXONOPODIS PV. PASSIFLORAE E SEVERIDADE DE COWPEA APHID-BORNE MOSAIC VIRUS (CABMV) EM PROGÊNIES DE MARACUJÁ AZEDO SOB CASA DE VEGETAÇÃO .......................... 37

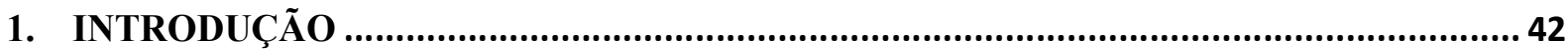

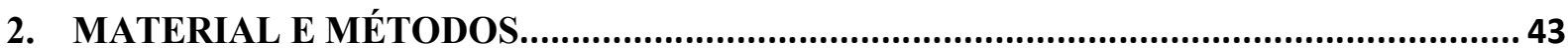

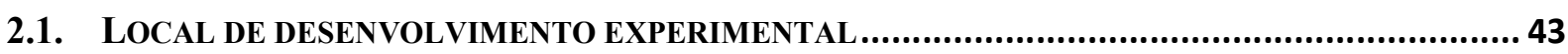

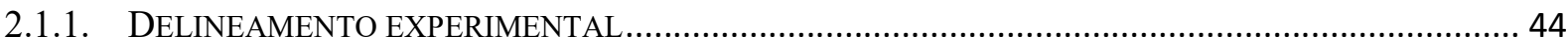

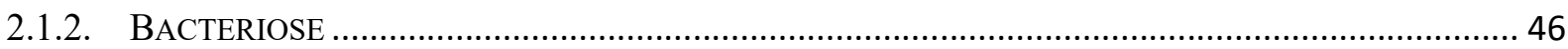

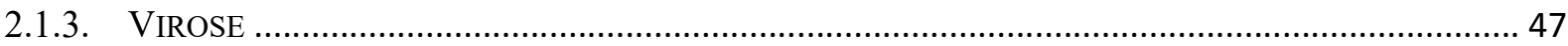

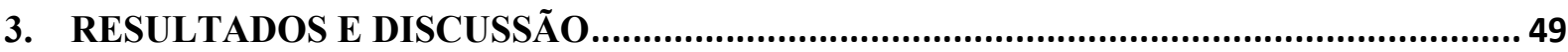

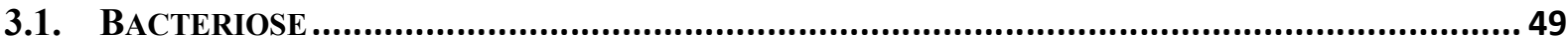

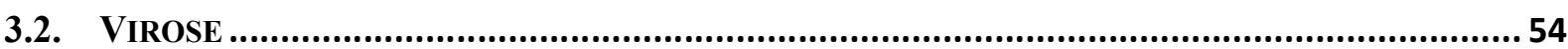

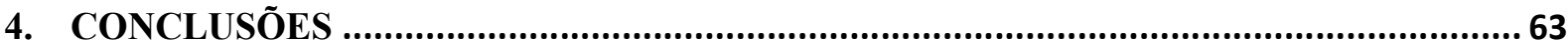


AVALIAÇÃO AGRONÔMICA E REAÇÃO A BACTERIOSE E VIROSE DE 10 PROGÊNIES

RESUMO 68

1. INTRODUÇÃ

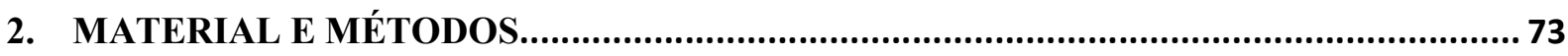

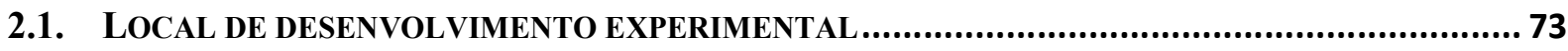

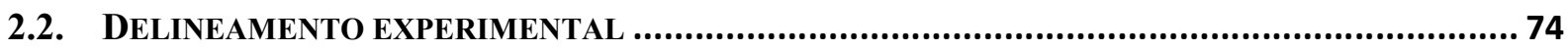

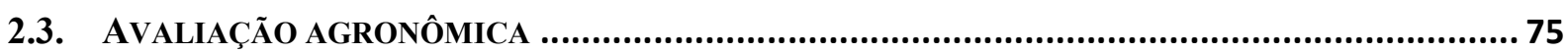

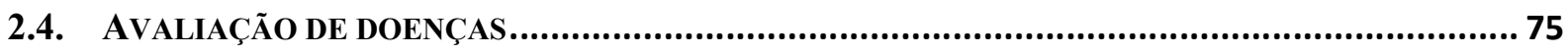

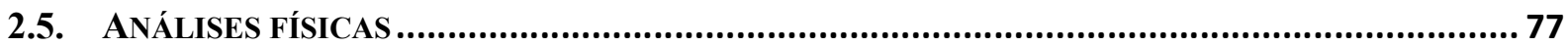

2.5.1. DETERMINAÇÃO DA MASSA, COMPRIMENTO E DIÂMETRO DO FRUTO...................................... 77

2.5.2. DETERMINAÇÃO DO RENDIMENTO DE POLPA, MASSA DE POLPA E CASCA, ESPESSURA DA

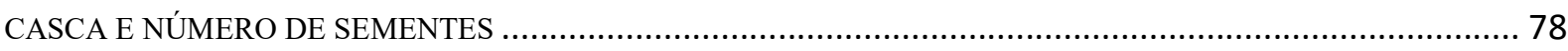

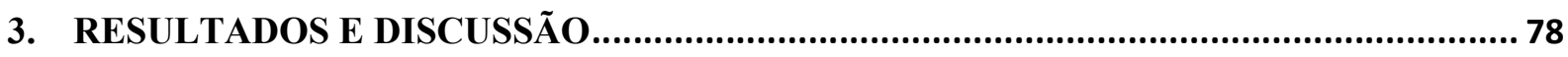

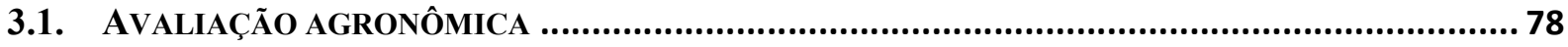

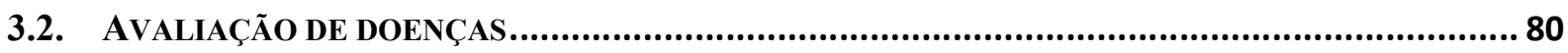

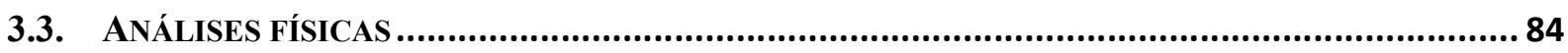

3.4. CORRELAÇÃO FENOTÍPICA ENTRE AS CARACTERÍSTICAS AGRONÔMICAS, DE ANÁLISE

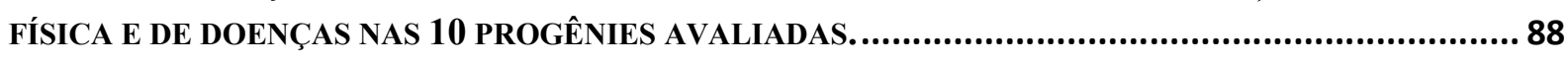

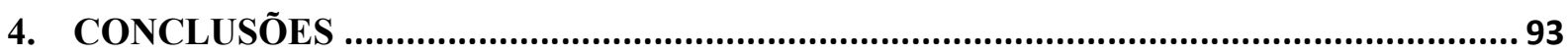

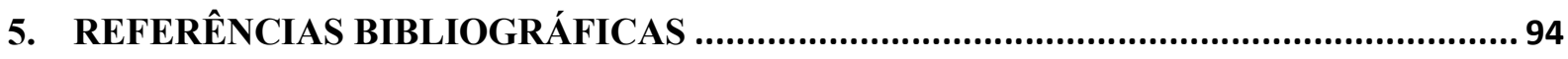

ANEXOS 


\section{1. ÍNDICE DE FIGURAS E TABELAS}

Figura 1. Dados climáticos da estação climatológica do Inmet, localizada na cidade satélite do Sudoeste, no período de 01 de março de 2015 à 30 de julho de 2015.

Figura 2.1. Incidência de CABMV em progênie de maracujazeiro azedo (Rubi Gigante) em 6 avaliações semanais. As curvas referem-se aos valores estimados e os pontos aos valores observados. Brasília-UnB, 2015.

Figura 2.2. Incidência de CABMV em progênie de maracujazeiro azedo (EC-RAM 3) em 6 avaliações semanais. As curvas referem-se aos valores estimados e os pontos aos valores observados. Brasília-UnB, 2015.

Figura 2.3. Incidência de CABMV em progênie de maracujazeiro azedo (ECL-7) em 6 avaliações semanais. As curvas referem-se aos valores estimados e os pontos aos valores observados. Brasília-UnB, 2015.

Figura 2.4. Incidência de CABMV em progênie de maracujazeiro azedo (MAR 20\#24 pl. 2) em 6 avaliações semanais. As curvas referem-se aos valores estimados e os pontos aos valores observados. Brasília-UnB, 2015.

Figura 2.5. Incidência de CABMV em progênie de maracujazeiro azedo (MAR 20\#41) em 6 avaliações semanais. As curvas referem-se aos valores estimados e os pontos aos valores observados. Brasília-UnB, 2015.

Figura 2.6. Incidência de CABMV em progênie de maracujazeiro azedo (Gigante Amarelo pl.1) em 6 avaliações semanais. As curvas referem-se aos valores estimados e os pontos aos valores observados. Brasília-UnB, 2015.

Figura 2.7. Incidência de CABMV em progênie de maracujazeiro azedo (EC3-0) em 6 avaliações semanais. As curvas referem-se aos valores estimados e os pontos aos valores observados. Brasília-UnB, 2015.

Figura 2.8. Incidência de CABMV em progênie de maracujazeiro azedo (MAR 20\#21) em 6 avaliações semanais. As curvas referem-se aos valores estimados e os pontos aos valores observados. Brasília-UnB, 2015.

Figura 2.9. Incidência de CABMV em progênie de maracujazeiro azedo (MSCA) em 6 avaliações semanais. As curvas referem-se aos valores estimados e os pontos aos valores observados. Brasília-UnB, 2015

Figura 2.10. Incidência de CABMV em progênie de maracujazeiro azedo (Rosa Intenso) em 6 avaliações semanais. As curvas referem-se aos valores estimados e os pontos aos valores observados. Brasília-UnB, 2015. 


\section{Anexos}

Figura 2.11 - Severidade de CABMV em progênie de maracujazeiro azedo (Rubi Gigante) em 6 avaliações semanais. As curvas referem-se aos valores estimados e os pontos aos valores observados. Brasília-UnB, 2015. .98

Figura 2.12 - Severidade de CABMV em progênie de maracujazeiro azedo (EC-RAM 3) em 6 avaliações semanais. As curvas referem-se aos valores estimados e os pontos aos valores observados. Brasília-UnB, 2015. . .98

Figura 2.13 - Severidade de CABMV em progênie de maracujazeiro azedo (ECL-7) em 6 avaliações semanais. As curvas referem-se aos valores estimados e os pontos aos valores observados. Brasília-UnB, 2015.

Figura 2.14 - Severidade de CABMV em progênie de maracujazeiro azedo (MAR 20\#24 pl. 2) em 6 avaliações semanais. As curvas referem-se aos valores estimados e os pontos aos valores observados. Brasília-UnB, 2015.

Figura 2.15 - Severidade de CABMV em progênie de maracujazeiro azedo (MAR 20\#41) em 6 avaliações semanais. As curvas referem-se aos valores estimados e os pontos aos valores observados. Brasília-UnB, 2015.

Figura 2.16 - Severidade de CABMV em progênie de maracujazeiro azedo (Gigante Amarelo pl. 1) em 6 avaliações semanais. As curvas referem-se aos valores estimados e os pontos aos valores observados. Brasília-UnB, 2015. 100

Figura 2.17 - Severidade de CABMV em progênie de maracujazeiro azedo (EC3-0) em 6 avaliações semanais. As curvas referem-se aos valores estimados e os pontos aos valores observados. Brasília-UnB, 2015. 100

Figura 2.18 - Severidade de CABMV em progênie de maracujazeiro azedo (MAR 20\#21) em 6 avaliações semanais. As curvas referem-se aos valores estimados e os pontos aos valores observados. Brasília-UnB, 2015.

Figura 2.19 - Severidade de CABMV em progênie de maracujazeiro azedo (MSCA) em 6 avaliações semanais. As curvas referem-se aos valores estimados e os pontos aos valores observados. Brasília-UnB, 2015. 101

Figura 2.20 - Severidade de CABMV em progênie de maracujazeiro azedo (Rosa Intenso) em 6 avaliações semanais. As curvas referem-se aos valores estimados e os pontos aos valores observados. Brasília-UnB, 2015. 101

Figura 3.1 - Incidência de bacteriose em progênie de maracujazeiro azedo (Rosa Intenso) em 6 avaliações semanais. As curvas referem-se aos valores estimados e os pontos aos valores observados. Brasília-UnB, 2015. 
Figura 3.2 - Incidência de bacteriose em progênie de maracujazeiro azedo (Gigante Amarelo pl. 1) em 6 avaliações semanais. As curvas referem-se aos valores estimados e os pontos aos valores observados. Brasília-UnB, 2015. 102

Figura 3.3 - Incidência de bacteriose em progênie de maracujazeiro azedo (MAR 20\#24 pl. 2) em 6 avaliações semanais. As curvas referem-se aos valores estimados e os pontos aos valores observados. Brasília-UnB, 2015. 103

Figura 3.4 - Incidência de bacteriose em progênie de maracujazeiro azedo (ECL-7) em 6 avaliações semanais. As curvas referem-se aos valores estimados e os pontos aos valores observados. Brasília-UnB, 2015. 103

Figura 3.5 - Incidência de bacteriose em progênie de maracujazeiro azedo (MAR 20\#21) em 6 avaliações semanais. As curvas referem-se aos valores estimados e os pontos aos valores observados. Brasília-UnB, 2015. 103

Figura 3.6 - Incidência de bacteriose em progênie de maracujazeiro azedo (EC3-0) em 6 avaliações semanais. As curvas referem-se aos valores estimados e os pontos aos valores observados. Brasília-UnB, 2015. .104

Figura 3.7 - Incidência de bacteriose em progênie de maracujazeiro azedo (MSCA) em 6 avaliações semanais. As curvas referem-se aos valores estimados e os pontos aos valores observados. Brasília-UnB, 2015. 104

Figura 3.8 - Incidência de bacteriose em progênie de maracujazeiro azedo (MAR 20\#41) em 6 avaliações semanais. As curvas referem-se aos valores estimados e os pontos aos valores observados. Brasília-UnB, 2015. 104

Figura 3.9 - Incidência de bacteriose em progênie de maracujazeiro azedo (EC-RAM 3) em 6 avaliações semanais. As curvas referem-se aos valores estimados e os pontos aos valores observados. Brasília-UnB, 2015. 105

Figura 3.10 - Incidência de bacteriose em progênie de maracujazeiro azedo (Rubi Gigante) em 6 avaliações semanais. As curvas referem-se aos valores estimados e os pontos aos valores observados. Brasília-UnB, 2015. 105

Figura 3.11 - Severidade de bacteriose em progênie de maracujazeiro azedo (Rosa Intenso) em 6 avaliações semanais. As curvas referem-se aos valores estimados e os pontos aos valores observados. Brasília-UnB, 2015.

Figura 3.12 - Incidência de bacteriose em progênie de maracujazeiro azedo (Gigante Amarelo pl. 1) em 6 avaliações semanais. As curvas referem-se aos valores estimados e os pontos aos valores observados. Brasília-UnB, 2015. 106

Figura 3.13 - Incidência de bacteriose em progênie de maracujazeiro azedo (MAR 20\#24 pl. 2) em 6 avaliações semanais. As curvas referem-se aos valores estimados e os pontos aos valores observados. Brasília-UnB, 2015. 106 
Figura 3.14 - Incidência de bacteriose em progênie de maracujazeiro azedo (ECL-7) em 6 avaliações semanais. As curvas referem-se aos valores estimados e os pontos aos valores observados. Brasília-UnB, 2015. 106

Figura 3.15 - Incidência de bacteriose em progênie de maracujazeiro azedo (MAR 20\#21) em 6 avaliações semanais. As curvas referem-se aos valores estimados e os pontos aos valores observados. Brasília-UnB, 2015. 107

Figura 3.16 - Incidência de bacteriose em progênie de maracujazeiro azedo (EC-RAM 3) em 6 avaliações semanais. As curvas referem-se aos valores estimados e os pontos aos valores observados. Brasília-UnB, 2015. 107

Figura 3.17 - Incidência de bacteriose em progênie de maracujazeiro azedo (MSCA) em 6 avaliações semanais. As curvas referem-se aos valores estimados e os pontos aos valores observados. Brasília-UnB, 2015.

Figura 3.18 - Incidência de bacteriose em progênie de maracujazeiro azedo (MAR 20\#41) em 6 avaliações semanais. As curvas referem-se aos valores estimados e os pontos aos valores observados. Brasília-UnB, 2015. 108

Figura 3.19 - Incidência de bacteriose em progênie de maracujazeiro azedo (EC-RAM 3) em 6 avaliações semanais. As curvas referem-se aos valores estimados e os pontos aos valores observados. Brasília-UnB, 2015. 108

Figura 3.20 - Incidência de bacteriose em progênie de maracujazeiro azedo (Rubi Gigante) em 6 avaliações semanais. As curvas referem-se aos valores estimados e os pontos aos valores observados. Brasília-UnB, 2015. 108

Figura 4 - Pomar de maracujazeiro azedo (Passiflora edulis Sims). Fazenda Água Limpa (FAL)$\mathrm{UnB}, 2015$.

Figura 5- Preparo de mudas de maracujazeiro azedo (Passiflora edulis Sims) para inoculação. Estação Experimental de Biologia-UnB, 2015. 109

Figura 6- Mudas de maracujazeiro azedo (Passiflora edulis Sims) para inoculação. Estação Experimental de Biologia-UnB, 2015.

Figura 7- Inoculação de bacteriose em mudas de maracujazeiro azedo (Passiflora edulis Sims). Estação Experimental de Biologia-UnB, 2015.

Figura 8-Câmara úmida feita após a inoculação de bacteriose em mudas de maracujazeiro azedo (Passiflora edulis Sims). Estação Experimental de Biologia-UnB, 2015. 110

Figura 9- Retirada da polpa de frutos de maracujá azedo (Passiflora edulis Sims) para análises físicas. Estação Experimental de Biologia-UnB, 2015.

\section{Capítulo 1}


Tabela 1. Progênies originais de maracujazeiro azedo avaliados no Distrito Federal, e suas respectivas procedências.

Tabela 2. Incidência na folha e severidade da bacteriose (Xanthomonas axonopodis pv. passiflorae) em 10 progênies de maracujazeiro azedo (Passiflora edulis Sims), sob diferentes épocas de avaliação em casa de vegetação. Brasília, UnB, 2015

Tabela 3. Média da incidência da bacteriose (Xanthomonas axonopodis pv. passiflorae) em folha e severidade em 10 progênies de maracujazeiro azedo (Passiflora edulis Sims), em seis épocas de avaliação em casa de vegetação. Brasília, UnB, 2015.

Tabela 4. Interação entre época e progênie na avaliação de incidência na folha da bacteriose (Xanthomonas axonopodis pv. passiflorae) em 10 progênies de maracujazeiro azedo (Passiflora edulis Sims), em casa de vegetação. Brasília, UnB, 2015.

Tabela 5. Interação entre época e progênie na avaliação de severidade da bacteriose (Xanthomonas axonopodis pv. passiflorae) em 10 progênies de maracujazeiro azedo (Passiflora edulis Sims), em casa de vegetação. Brasília, UnB, 2015. . .51

Tabela 6. Efeito da bacteriose (Xanthomonas axonopodis pv. passiflorae) em progênies de maracujazeiro azedo (Passiflora edulis Sims) a partir das médias da área abaixo da curva de progresso da doença (AACPD) obtida pelo índice de severidade de doença, em casa de vegetação. Brasília, UnB, 2015. .52

Tabela 7. Ponto máximo de incidência e severidade da bacteriose (Xanthomonas axonopodis pv. passiflorae) em progênies de maracujazeiro azedo (Passiflora edulis Sims), dias após inoculação, estimada através de regressão quadrática. Brasília, UnB, 2015

Tabela 8. Resumo da análise de variância dos dados relativos à severidade da bacteriose (Xanthomonas axonopodis pv. passiflorae) em 10 progênies de maracujazeiro azedo (Passiflora edulis Sims), cultivados em casa de vegetação na Estação Experimental Biológica. Brasília, UnB, 2015. .54

Tabela 9. Severidade da virose do endurecimento dos frutos (Cowpea aphid-borne virus) em 10 progênies de maracujazeiro azedo (Passiflora edulis Sims), em diferentes épocas de avaliação, em casa de vegetação. Brasília, UnB, 2015

Tabela 10. Média da severidade da virose do endurecimento dos frutos (Cowpea aphid-borne virus) em 10 progênies de maracujazeiro azedo (Passiflora edulis Sims), em seis épocas de avaliação, em casa de vegetação. Brasília, UnB, 2015.

Tabela 11. Interação entre época e progênie na avaliação de severidade da virose do endurecimento dos frutos (Cowpea aphid-borne virus), em 10 progênies de maracujazeiro azedo (Passiflora edulis Sims), em casa de vegetação. Brasília, UnB, 2015. . .56

Tabela 12. Efeito da virose do endurecimento dos frutos (Cowpea aphid-borne virus) em progênies de maracujazeiro azedo (Passiflora edulis Sims) a partir das médias da área abaixo da 
curva de progresso da doença (AACPD) obtida pelo índice de severidade de doença em casa de vegetação. Brasília, UnB, 2015

Tabela 13. Ponto máximo de incidência e severidade da virose do endurecimento dos frutos (Cowpea aphid-borne virus), em maracujazeiro azedo (Passiflora edulis Sims), dias após inoculação, estimada através de regressão quadrática. Brasília, UnB, 2015.

Tabela 14. Resumo da análise de variância dos dados relativos a incidência da virose do endurecimento dos frutos (Cowpea aphid-borne virus), em 10 progênies de maracujazeiros, cultivados em casa de vegetação na Estação Experimental Biologia. Brasília, UnB, 2015.

\section{Capítulo 2}

Tabela 1. Classificação dos frutos de maracujazeiro azedo (Passiflora edulis Sims) de acordo com o seu diâmetro equatorial $(\mathrm{mm})$, utilizada na avaliação de 10 progênies cultivados na Fazenda Água Limpa - UnB, Brasília, 2014 a 2015, segundo proposta de RANGEL (2002)

Tabela 2. Classificação de incidência e a severidade (\%), utilizada na avaliação de bacteriose (Xanthomonas axonopodis pv. passiflorae) em 10 progênies de maracujazeiro azedo (Passiflora edulis Sims) cultivados na Fazenda Água Limpa - UnB, Brasília, 2015, segundo proposta de JUNQUEIRA et al. (2003). . .76

Tabela 3. Notas e sintomas visuais utilizados para análise das folhas na avaliação da virose do endurecimento dos frutos (Cowpea aphid-borne mosaic virus) em 10 progênies de maracujazeiro azedo (Passiflora edulis Sims) cultivados na Fazenda Água Limpa - UnB, Brasília, 2015, segundo proposta de SOUSA (2005) . .77

Tabela 4. Produtividade total estimada e número total de frutos por hectare de 10 progênies de maracujazeiro azedo (Passiflora edulis Sims) cultivadas na Fazenda Água Limpa durante 40 colheitas. Brasília, Dez/2014 - Jun/2015.

Tabela 5. Avaliação agronômica de 10 progênies de maracujazeiro azedo (Passiflora edulis Sims) cultivadas na Fazenda Água Limpa durante 40 colheitas. Brasília, Dez/2014 Jun/2015

Tabela 6. Avaliação de incidência e severidade da bacteriose e virose em 10 progênies de maracujazeiro azedo (Passiflora edulis Sims) cultivadas na Fazenda Água Limpa, durante 3 avaliações. Brasília, Mar-Mai de 2015.

Tabela 7. Incidência, severidade e grau de resistência de 10 progênies à bacteriose (Xanthomonas axonopodis pv. passiflorae) em folhas de maracujazeiro azedo (Passiflora edulis Sims) cultivadas na Fazenda Água Limpa durante 3 avaliações. Brasília, Mar- Mai de 2015.

Tabela 8. Incidência, severidade e grau de resistência de 10 progênies à virose do endurecimento dos frutos (Cowpea aphid-borne mosaic virus) em folhas de maracujazeiro azedo (Passiflora 
edulis Sims) cultivadas na Fazenda Água Limpa durante 3 avaliações. Brasília, Mar- Mai de 2015. .83

Tabela 9. Variáveis significativas das análises físicas de 10 progênies de maracujazeiro azedo (Passiflora edulis Sims) cultivadas na Fazenda Água Limpa. Brasília, 84

Tabela 10. Média das variáveis significativas das análises físicas de 10 progênies de maracujazeiro azedo (Passiflora edulis Sims) cultivadas na Fazenda Água Limpa. Brasília, 2015 .85

Tabela 11. Valores do coeficiente de correlação de Pearson entre as variáveis resposta analisadas. Brasília 2005. .91 


\section{RESUMO GERAL}

O cultivo do maracujá tem adquirido grande importância no contexto mundial, sendo que o Brasil ocupa uma posição de destaque como maior produtor e consumidor mundial da fruta. Entretanto, a baixa produtividade e a alta suscetibilidade à doenças são dificuldades enfrentadas por esta cultura, reforçando a necessidade de pesquisas contínuas voltadas para o desenvolvimento de variedades produtivas, com boa qualidade de fruto e resistentes à doenças. $\mathrm{O}$ objetivo deste trabalho foi avaliar 10 progênies maracujá azedo, quanto à resistência à bacteriose (Xanthomonas axonopodis pv. passiflorae) e à virose (Cowpea aphid-borne vírus), em casa de vegetação, bem como realizar a avaliação agronômica e de resistência a estas doenças, sob condições de campo, no Distrito Federal. Para a avaliação de resistência à doenças em casa de vegetação, os isolados da bactéria e do vírus foram inoculados mecanicamente, sendo avaliadas a incidência e/ou severidade das doenças nas folhas das plantas. Diferenças entre as progênies foram encontradas quanto à incidência e à severidade das doenças, sendo que Rosa Intenso, MSCA e EC30 destacaram-se como as progênies com menor severidade da virose. Apenas a progênie MAR 20\#24 pl. 2 foi classificada como suscetível à virose enquanto as demais progênies foram classificadas como moderadamente resistentes. Gigante Amarelo pl. 1, Rosa Intenso e MAR20\#24 pl. 2 apresentaram as menores severidades e incidências de bacteriose, mas apenas Rosa Intenso foi classificada como moderadamente suscetível. As demais progênies foram consideradas suscetíveis à bacteriose. A avaliação agronômica considerou a produtividade estimada $(\mathrm{kg} / \mathrm{ha})$, número total de frutos por hectare, e a classificação dos frutos quanto ao diâmetro equatorial em cinco categorias. Nas análises físicas, foram determinadas as massas do fruto, da polpa e da casca $(\mathrm{g})$, o comprimento e o diâmetro do fruto $(\mathrm{mm})$, rendimento de polpa (\%), espessura da casca $(\mathrm{mm})$ e $\mathrm{n}^{\mathrm{o}}$ de sementes de 5 frutos de cada parcela. Para a avaliação da reação das progênies quanto à resistência à bacteriose e à virose no campo, foram realizadas análises nos frutos (bacteriose) e nas folhas (virose). ECL-7, Gigante Amarelo pl. 1 e MAR 20\#41 destacaram-se como as progênies com maiores produtividades totais estimadas e maiores números de frutos. MSCA, Gigante Amarelo pl. 1 e MAR 20\#41 mostraram as maiores produtividades de frutos destinados à indústria (primeira e 1B) enquanto MAR 20\#21 obteve maior produtividade de frutos destinados ao consumo in natura (1A e 2A). Todas as progênies avaliadas em campo mostraram-se moderadamente suscetíveis à virose, 
sendo que MAR 20\#21 e Gigante Amarelo pl. 1 apresentaram menor incidência e severidade da doença, respectivamente. Para a bacteriose, as progênies Rosa Intenso e MSCA obtiveram as menores incidência e severidade, respectivamente. Cinco progênies foram classificadas como resistentes e as outras 5 , como moderadamente suscetíveis. EC3-0 destacou-se como a progênie com maior comprimento de fruto e MAR 20\#21, como a de maior rendimento de polpa. ECL-7 obteve os menores valores de comprimento de fruto, rendimento de polpa e massas de fruto, polpa e casca. Foram observadas correlações positivas entre a severidade e a incidência de cada doença e entre as características: produção total/ número total de frutos e quilogramas por hectare; número de frutos por planta e número de frutos por hectare.

Palavras-chave: Passiflora edulis Sims, produtividade, resistência à doenças, melhoramento. 


\section{ABSTRACT}

Passion fruit cultivation has acquired great importance in the global market, and Brazil stands out as the largest passion fruit producer and consumer in the world. However, low fruit yield and high disease susceptibility are some of the major issues faced by passion fruit crop, supporting the need of continuous studies focused on the development of high yield varieties, with good fruit quality, and disease resistance. The objective of this study was to evaluate 10 progenies of sour passion fruit regarding their resistance to the bacterial spot disease (Xanthomonas axonopodis pv. passiflorae) and to the passion fruit woodiness virus disease (PWD) (Cowpea aphid-borne mosaic virus - CABMV), under greenhouse conditions, as well as to perform agronomic and disease resistance evaluations, under field conditions, at Distrito Federal. For greenhouse disease evaluations, bacteria and virus isolates were mechanically inoculated in the leaves, which were used for disease incidence and severity assessments. Differences between progenies were found for diseases incidence and severity. Rosa Intenso, MSCA, and EC3-0 stood out as the progenies with lowest PWD severity. MAR 20\#24 pl. 2 was the only progeny classified as susceptible to PWD whereas the remaining progenies were classified as moderately resistant. Gigante Amarelo pl. 1, Rosa Intenso, and MAR20\#24 pl. 2 presented the lowest bacterial spot severity and incidence. However, only Rosa Intenso was classified as moderately susceptible. The remaining progenies were considered susceptible to the bacterial spot disease under the tested conditions. The agronomic evaluation assessed the estimated yield $(\mathrm{kg} / \mathrm{ha})$, total number of fruits per hectare, and fruit classification into five categories based on their equatorial diameter. Physical analyses consisted on the evaluation of fruit, pulp, and peel masses $(\mathrm{g})$, fruit length and diameter $(\mathrm{mm})$, fruit length/diameter ratio, pulp yield $(\%)$, peel thickness $(\mathrm{mm})$, and number of seeds from 5 fruits per parcel. For progenies disease reaction evaluation, fruits (bacterial spot) and leaves (PWD) were analysed for disease incidence and severity. ECL7, Gigante Amarelo pl. 1, and MAR 20\#41 stood out as the progenies with greatest total estimated yields and fruit numbers. MSCA, Gigante Amarelo pl. 1, and MAR 20\#41 showed the greatest yields for fruits destined to industry (types first and 1B), whereas MAR 20\#21 revealed the highest yield for fruits destined to in natura consumption (1A and $2 \mathrm{~A}$ ). All progenies evaluated under field conditions were considered moderately 
susceptible to PWD. MAR 20\#21 and Gigante Amarelo pl. 1 presented the lowest disease incidence and severity, respectively. For bacterial spot, progenies Rosa Intenso and MSCA showed the lowest disease incidence and severity, respectively. Five progenies were classified as resistant and the remaining progenies were classified as moderately susceptible. EC3-0 was the progeny with greatest fruit length and MAR 20\#21 was the progeny with greatest pulp yield. ECL-7 exhibited the lowest fruit length, pulp yield, and fruit, pulp, and peel masses. Positive correlations were found between incidence and severity from each disease as well as between the following traits: total production/total number of fruits and kilograms per hectare; number of fruit per plant and number of fruit per hectare.

Keywords: Passiflora edulis Sims, yield, disease resistance, breeding. 


\section{INTRODUÇÃO GERAL}

Maracujá é um fruto produzido pelas plantas do gênero Passiflora, pertencente à família Passifloraceae, originária da América Tropical. Passiflora edulis Sims, mais conhecida como maracujá azedo, é a espécie de maior importância econômica, devido seu bom rendimento de suco e aceitação no mercado (RUGGIERO et al., 1996; CUNHA et al., 2002; VILELA, 2013).

Segundo dados do IBGE, a produção brasileira em 2012 foi cerca de 776.097 toneladas, em uma área de 57.848 ha. A produtividade média brasileira é estimada em 13,42 toneladas ha/ano, entretanto, o potencial da cultura pode chegar a 50 toneladas ha/ano, através da utilização de cultivares melhoradas geneticamente e tecnologias adequadas no sistema de produção.

A alta incidência e severidade das doenças vem diminuindo a produtividade nos últimos anos. Essas doenças não só afetam a qualidade do fruto, diminuindo seu valor comercial, como também diminuem a produtividade e a longevidade dos pomares (MELETTI et al., 2005).

O maracujazeiro pode ser atacado por diversos fungos, vírus e bactérias, causando algumas doenças, das quais podemos destacar a bacteriose (Xanthomonas axonopodis pv. passiflorae) e a virose do endurecimento dos frutos (Cowpea aphid-borne mosaic virus - CABMV). Tais doenças podem causar morte precoce, diminuindo a vida útil da planta, desfolhamento, retardamento na maturação do fruto, ocorrência de frutos com baixo rendimento de polpa, além de queda na qualidade e produtividade, gerando prejuízos de ordem social e financeira, pois o controle curativo das doenças é oneroso e muitas vezes não apresentam eficiência satisfatória (DIAS, 1990; MIRANDA, 2004; FALEIRO et al., 2005).

As características desejadas no fruto variam de acordo com a finalidade para que o mesmo se destina. Em termos de qualidade considera-se que uma variedade desenvolvida para o mercado in natura deve apresentar frutos grandes e ovais, cavidade interna completamente preenchida, visando uma boa classificação comercial, ser resistente ao transporte e a perda de qualidade durante armazenamento e comercialização. Se a produção for voltada para indústria, é necessário ter casca fina, apresentar cavidade interna completamente preenchida, conferindo alto rendimento de suco, possuir polpa com coloração amarelo-dourada estável e alto teor de sólidos solúveis, superior a $13^{\circ}$ Brix (OLIVEIRA et al., 1994; BRUCKNER et al., 2002). 
Segundo JUNQUEIRA et al. (2005), a produtividade da cultura do maracujá é considerada baixa. Muitos fatores influenciam essa característica, sendo o cultivo de variedades inadequadas um deles.

A baixa produtividade é um dos principais problemas da cultura, enfatizando a necessidade de pesquisas voltadas para o desenvolvimento de variedades melhoradas e estabelecimento de tecnologias de produção capazes de proporcionar aumento da produtividade, possibilidade de aumento da sobrevida da cultura e melhoria da qualidade dos frutos (RUGGIERO, 2000).

A carência de materiais genéticos com alta produtividade, qualidade de frutos e resistência a fitopatógenos para atender a demanda de produtores das diferentes regiões do Brasil demanda trabalhos de pesquisa e desenvolvimento nas diversas áreas do conhecimento, o que exige um trabalho integrado e contínuo, principalmente na área de melhoramento genético.

Nesse contexto, o presente trabalho tem por objetivo a avaliação agronômica de progênies de maracujazeiro produzidos no Distrito Federal e avaliação de progênies quanto a resistência a mancha oleosa (Xanthomonas axonopodis pv. passiflorae) e a virose do endurecimento do fruto (Cowpea aphid-borne mosaic virus - CABMV), em casa de vegetação. 


\section{REVISÃO DE LITERATURA}

\subsection{Aspectos botânicos}

Pertencente à família Passifloraceae, o maracujazeiro é uma planta trepadeira, semilenhosa, de crescimento rápido e frutificação precoce (RUGGIERO et al., 1996), podendo atingir de 5 a 10 metros de comprimento. É uma dicotiledônea, com ciclo de vida médio entre 3 a 6 anos (MANICA, 1997) e apresenta grande vigor vegetativo. O Brasil possui cerca de 70 espécies nativas que produzem frutos, que podem vir a ser aproveitados direta ou indiretamente como alimento (CUNHA et al., 2002).

Segundo MANICA, (1981) o caule, de secção circular, é lenhoso e bastante lignificado, diminuindo o teor de lignina à medida que se aproxima do ápice da planta. Na parte do caule, surgem as gemas vegetativas, cada uma dando origem a uma folha e a uma gavinha de coloração avermelhada.

As folhas são simples e alternadas, possuindo na fase juvenil das plantas a forma ovalada e, na fase adulta, a forma digitada ou lobada. Condições adversas levam à queda das folhas, que voltam a brotar no ciclo seguinte. Já em boas condições, as folhas são permanentes (RUGGIERO et al., 1996; MANICA, 1997).

As flores são hermafroditas, actinomorfas, isoladas ou aos pares, situadas nas axilas das folhas e, geralmente, agrupadas em inflorescências racemosas, pseudoracemosas ou fasciculadas. O tubo floral pode possuir forma de bacia, taça ou campânula, apresentando coloração verde em tubos desenvolvidos. São cinco sépalas carnosas ou membranáceas, lineares e aristadas. As pétalas são formadas no tubo calicinal e são menores e alternadas com as sépalas (CUNHA et al., 2004).

O fruto possui formato ovóide e a baga é fixada através de um pedúnculo, com epicarpo (casca) às vezes lignificado. Possui casca de textura coriácea e a coloração varia do amarelo intenso ao roxo no final da maturação. O mesocarpo tem uma espessura que varia entre 0,5 a 4,0 cm, é carnoso e no seu interior encontram-se o endocarpo (polpa), e as sementes recobertas pelo arilo carnoso, o qual contém uma polpa amarela e aromática (DURIGAN, 2002).

De acordo com CÓRDOVA et al., (2005), o fruto do maracujá azedo (Passiflora edulis Sims) é rico em vitamina $\mathrm{C}$, cálcio e fósforo, sendo a espécie mais popular e a de maior interesse para a indústria. 
O maracujazeiro pode ser propagado pelas formas sexuada, por sementes, e assexuada, por enxertia, estaquia ou cultura de tecidos in vitro (NEGREIROS et al., 2006). É classificada como planta de "dias longos", necessitando entre 11 a 12 horas de luz para florescer, e apresenta queda de produção quando exposta a menores níveis de radiação solar (CAVICHIOLI et al., 2006).

\subsection{A cultura do maracujá}

A fruticultura é considerada uma das atividades mais dinâmicas da economia brasileira. Possui um mercado interno em crescimento e vem ganhando espaço no mercado internacional, com frutas tropicais, subtropicais e de clima temperado, aumentando o volume das exportações, o número de empresas exportadoras, as variedades de frutas exportadas e os países de destino das exportações.

O gênero Passiflora é composto por cerca de 525 espécies, das quais de 150 a 200 são originárias do Brasil. Cerca de 70 dessas espécies produzem frutos comestíveis (CUNHA et al., 2002), proporcionando uma ampla variabilidade genética a ser explorada, utilizada comercialmente ou em programas de melhoramento genético (FALEIRO et al., 2011).

O maracujá tem adquirido grande importância no contexto mundial, notadamente a partir das últimas três décadas, sendo que o Brasil ocupa uma situação de destaque como maior produtor e consumidor mundial da fruta (FALEIRO et al., 2008).

O Brasil possui como principais Estados produtores de maracujá a Bahia $(42,35 \%$ da produção), o Ceará (25,52\% da produção), o Espirito Santo (5,73\% da produção), Minas Gerais (3,95\% da produção) e Sergipe (3,85\% da produção), sendo os demais estados responsáveis pelo restante da produção (18,60\%) (IBGE, 2015).

Segundo dados preliminares do IBGE, foram colhidas mais de 510.000 toneladas em uma área de 41.500 ha no decorrer da safra 2013/2014, apresentando uma queda de 15\% em relação à safra 2012/13 (REVISTA CAMPO E NEGÓCIO, 2015). A produtividade média brasileira é estimada em 13,42 toneladas ha/ano, entretanto, o potencial da cultura pode chegar a 50 toneladas ha/ano, através da utilização de cultivares melhoradas geneticamente e práticas de manejo da cultura (FALEIRO et al., 2011).

Nos últimos anos, a produção nacional foi insuficiente para abastecer o consumo interno do Brasil, havendo necessidade de importação de polpa de outros países para abastecer a indústria de sucos nacional (FERRAZ \& LOT, 2007). 
As espécies com maior expressão comercial são a (Passiflora edulis Sims) (maracujá azedo) e a Passiflora alata (maracujá-doce), responsáveis por 95\% da área plantada no Brasil (IBGE, 2015). Apesar da grande importância econômica e potencial do maracujá, o número de cultivares comerciais ainda é muito pequeno, sendo os plantios comerciais, na maioria das vezes, limitados ao emprego de sementes obtidas em pomares comerciais (VILELA, 2013).

A baixa produtividade decorrente de problemas fitossanitários e a carência de variedades adaptadas aos diferentes agroecossistemas desestimulam os produtores. Diante desse contexto, pode-se inferir que há espaço para expansão da cultura no país, tanto em função do déficit na produção quanto no aumento da demanda pela fruta nos últimos anos. Porém, são necessários maiores investimentos em ações de pesquisa e desenvolvimento a fim de dar suporte técnico à atividade.

\subsection{Melhoramento do maracujazeiro azedo visando a resistência à doenças}

Durante as décadas de 80 e 90, foram reportados no Brasil, vários problemas fitossanitários no manejo do maracujazeiro azedo (KIMATI et al., 1997). Doenças como virose do endurecimento dos frutos (Cowpea aphid-borne mosaic virus, CABMV), bacteriose ou mancha bacteriana (Xanthomonas campestris pv. Passiflorae), murcha de fusarium (Fusarium oxysporum), verrugose ou cladosporiose (Cladosporium herbarum Link) e antracnose (Colletotrichum gloesporioides) causaram grandes prejuízos e até mesmo inviabilizaram economicamente a cultura em algumas regiões do país.

O melhoramento genético deve visar um melhor desempenho agronômico do maracujá, com a obtenção de plantas vigorosas, frutos com padrão de qualidade superior, considerando sabor, acidez, tamanho dos frutos e rendimento de suco e resistência a doenças, sem deixar de atender as exigências de mercado e dos produtores com a redução de custos de produção e o aumento da produtividade (MELETTI et al., 2005).

Levando em conta a grande variabilidade genética do maracujazeiro, alguns programas de melhoramento genético têm sido conduzidos visando à obtenção de variedades mais produtivas e resistentes a doenças (BARBOSA, 1998). Segundo JUNQUEIRA et al. (2005), entre as várias espécies de passifloras silvestres no Brasil, algumas têm características interessantes que poderiam ser introduzidas no maracujazeiro comercial, como por exemplo a maior resistência a pragas e a algumas doenças, entre outras características. 
Por se tratar de uma planta alógama, diversos métodos de melhoramento genético podem ser utilizados no maracujazeiro, visando o aumento da frequência de genes favoráveis ou à exploração da heterose. Segundo BRUCKNER \& OTONI (1999), os principais métodos de melhoramento utilizados são a introdução de plantas, a seleção massal, a hibridação sexual interespecífica, a hibridação sexual intervarietal e a seleção com teste de progênies.

A caracterização e a exploração da variabilidade genética das espécies de Passiflora podem revelar fontes de resistência ou tolerância de grande valor para o controle de doenças no campo ou utilização em programas de melhoramento genético (FALEIRO et al., 2005). No entanto, esses trabalhos ainda são recentes no Brasil. As primeiras cultivares de maracujá tornaram-se disponíveis somente a partir de 1998, mas já representam avanço considerável em produtividade e qualidade de frutos (BRUCKNER et al., 2005).

O número de cultivares comerciais de maracujá azedo registradas no Ministério da Agricultura, Pecuária e Abastecimento ainda é pequeno quando considerada a grande diversidade genética de Passiflora presente no país. Entre as cultivares registradas estão o FB 100 e FB 200 desenvolvidas pelo Viveiro Flora Brasil, o IAC-275 e IAC-277 desenvolvidos pelo Instituto Agronômico-IAC, e variedades lançadas pela Embrapa Cerrados e parceiros, denominadas BRS Rubi do Cerrado, BRS Ouro Vermelho, BRS Gigante Amarelo e BRS Sol do Cerrado (BELLON, 2014)

Estudos detalhados de caracterização, seleção e hibridação de genótipos de maracujazeiro são essenciais para subsidiar a utilização do germoplasma de Passiflora, podendo mostrar fontes de resistência ou tolerância de grande valor para o controle de doenças no campo, materiais produtivos, com boa qualidade de frutos, além de outras características buscadas em programas de melhoramento genético.

\subsection{Virose do Endurecimento dos Frutos}

Relatada pela primeira vez há mais de cem anos na Austrália (COBB, 1901), a virose do endurecimento dos frutos do maracujazeiro encontra-se disseminada nas maiores regiões produtoras e é considerada como a principal doença viral do maracujazeiro no Brasil (NASCIMENTO et al., 2004).

Até o início da década de 1990, acreditava-se que a única espécie de potyvirus causadora da virose do endurecimento dos frutos do marucujá fosse o Passion fruit 
woodiness virus (PWV). Entretanto ficou constatado na África do Sul que a doença também pode ser causada por uma estirpe do CABMV (NASCIMENTO, 2004).

Estudos com base na análise comparativa da sequência de aminoácidos da proteína capsidial $(\mathrm{CP})$ do PWV demonstraram que este possui alta identidade $(>85 \%)$ com o South african passiflora virus (SAPV) e o Cowpea aphid-borne mosaic virus (CABMV) (COSTA,1996). Entretanto o SAPV foi identificado como uma estirpe do CABMV (SITHOLE-NIANG et al., 1996), levando o Comite Internacional de Taxonomia de Vírus (ICTV) a reclassifica-lo como pertencente à espécie CABMV (VAN REGENMORTEL et al., 2000).

Dessa forma o endurecimento do fruto do maracujazeiro pode ser causado por duas espécies de vírus, Passionfruit woodiness virus (PWV) ou pelo Cowpea aphid-borne mosaic virus (CABMV) (VAN REGENMORTEL et al., 2000; ALFENAS et al., 2005). Ambos pertencentes ao gênero Potyvirus, possuem partícula alongada e flexuosa, com 690-760 nm de comprimento por 11-16 nm de largura. O genoma é constituído por um RNA de fita simples, sentido positivo, com aproximadamente 10.000 nucleotídeos (VAN REGENMORTEL et al., 2000).

De acordo com KITAJIMA et al. (1986), estudos baseados em caracterização biológica e sorológica consideraram o PWV como o agente etiológico do endurecimento dos frutos do maracujazeiro no Brasil. Porém, com o auxílio da caracterização molecular, constatou-se que os isolados virais responsáveis pela doença no Brasil pertenciam à espécie Cowpea aphid-borne mosaic virus (CABMV) (NASCIMENTO et al., 2004; NASCIMENTO et al., 2006; CERQUEIRA-SILVA et al., 2008).

$\mathrm{O}$ vírus do endurecimento dos frutos reduz consideravelmente o peso da parte aérea, a área foliar e o sistema radicular da planta. Como a produção do maracujazeiro está diretamente relacionada a área foliar da planta, os efeitos são visíveis. A ocorrência da doença é um dos principais fatores que tem contribuído para redução na produtividade e qualidade dos frutos. Quanto mais cedo a planta é infectada, maior é o efeito negativo (GIORIA, 1999; PIMENTEL et al., 2008; CERQUEIRA-SILVA et al., 2008).

Plantas de maracujá afetadas podem apresentar mosaicos, manchas anelares, clareamento das nervuras, rugosidade, distorção e mosqueado amarelo. Já os frutos infectados apresentam tamanho reduzido, deformações e endurecimento que, dependendo da intensidade dos sintomas, pode inviabilizar a comercialização dos mesmos (GIORIA et al., 2000; REZENDE, 2006). 
De acordo com KITAJIMA et al. (1986), o vírus é facilmente transmissível mecanicamente e por afídeos, principalmente da espécie Aphis gossypii, de maneira não persistente, não ocorrendo transmissão por sementes (VILLANOVA et al., 2007). A transmissão do vírus ocorre no momento das picadas de prova do inseto, caracterizando a relação vírus-vetor como sendo do tipo não circulativa e não persistente.

Evitar a disseminação da doença tem sido a única forma de preveni-la, impedindo a entrada do patógeno em áreas onde ele não se encontra presente. Estudos visam desenvolver métodos de controle por meio de resistência ou tolerância e pré-imunização com estirpes fracas (REZENDE, 1994) e desenvolvimento de plantas transgênicas (FALEIRO et al., 2011). A identificação de fontes de resistência é a etapa básica de todo programa de melhoramento genético.

\subsection{Bacteriose}

A bactéria Xanthomonas axonopodis pv. passiflorae (Pereira) Dye. foi descrita por PEREIRA (1969), no Estado de São Paulo, região de Araraquara, que a classificou como uma nova espécie, propondo a designação de $X$. passiflorae. Posteriormente, Dye et al, (1980) reclassificaram a bactéria, denominando-a de $X$. campestris pv. passiflorae. Analisando 54 linhagens do patógeno, GONÇALVES \& ROSATO (2000) detectaram, por meio de hibridação de DNA:DNA, um nível de homologia de $67 \%$ entre $X$. axonopodis e $X$. campestris pv. passiflorae, determinando que as linhagens de Xanthomonas de maracujazeiro pertenciam à espécie axonopodis. Desta forma, propuseram a sua reclassificação para $X$. axonopodis pv. passiflorae.

As Xanthomonas são bactérias gram-negativas, aeróbicas obrigatórias, possuem um único flagelo, apresentam forma de bastonete e coloração amarela, devido a presença do pigmento xantomonadina, característico do gênero (CIVEROLO, 1993; GONÇALVES \& ROSATO, 2000). Não apresentam formação de esporos e medem 0,5 X 1,5 mm. Segundo PEREIRA (1969), formam colônias características com nuances amarelo brilhantes, circulares, convexas, salientes, elevadas, translucidas, bordas regulares e viscosas.

A diagnose da bacteriose ou mancha oleosa do maracujazeiro é feita através da visualização dos sintomas seguida de teste de exsudação, isolamento e cultivo em meio de cultura e teste de patogenicidade. De acordo com PIO-RIBEIRO \& MARIANO (1997), os sintomas iniciais nas folhas, são lesões pequenas, encharcadas, oleosas, 
translúcidas, frequentemente localizadas próximas às nervuras, com halos visíveis, podendo ocorrer o enegrecimento vascular a partir das bordas foliares. Essas lesões necrosam, assumindo tonalidade marrom-avermelhada, principalmente na face dorsal da folha, podendo também formar um halo clorótico ao redor da mancha, de formato variado, raramente circulares, com tamanho médio de 3 a 4 mm (VIANA et al., 2003). Com o desenvolvimento da doença, ocorre seca das folhas e, posteriormente, a desfolha, reduzindo consideravelmente a produtividade.

A partir das lesões foliares, a infecção pode se tornar sistêmica e atingir todos os tecidos da planta, provocando a dessecação da planta, até a morte, em cultivares muito suscetíveis (JUNQUEIRA, 2007; VIANA et al., 2003). A doença pode causar imensa desfolha, que reduz drasticamente ou mesmo impede a formação de frutos (DIAS e TAKATSU, 1987). Nos frutos, as manchas são grandes, bem delimitadas, inicialmente esverdeadas e oleosas, podendo coalescer e causar lesões de grandes extensões. Essas manchas são superficiais, entretanto, em condições favoráveis, podem se aprofundar até as sementes e promover a sua fermentação, inviabilizando a comercialização dos frutos (HALFELD-VIEIRA, 2006; JUNQUEIRA, 2007; KIMATI, 2005; VIANA et al., 2003).

A utilização de mudas e sementes sadias é atualmente a medida de controle da doença de maior importância. A utilização de quebra-ventos, a prática de podas de limpeza, aplicação de bactericidas e o uso de plantas tolerantes ou resistentes são fundamentais para evitar grandes prejuízos. O desenvolvimento de variedades resistentes é tido como a medida mais efetiva no controle da doença por ter um baixo custo e não causar danos ambientais (SANTOS, 2003).

Nas condições do cerrado, o manejo da bacteriose vem sendo feito por meio da integração dos controles cultural, químico, e genético, com resultados satisfatórios para o maracujazeiro azedo. A erradicação das porções vegetais doentes pode ajudar a reduzir a epidemia. A termoterapia, utilizando água a $50{ }^{\circ} \mathrm{C}$, por 15 minutos é eficiente em eliminar o patógeno das sementes sem afetar o poder germinativo. A desinfestação das ferramentas de poda com produto bactericida, e em plantas adultas, aplicações quinzenais de oxicloreto de cobre a $30-50 \%$ ou oxicloreto de cobre + maneb + zineb, reduzem a intensidade da doença. (KIMATI et al., 2005; JUNQUEIRA, 2007).

Embora o conhecimento da resistência genética de Passiflora à bacteriose do maracujazeiro ainda seja insuficiente, resultados obtidos têm indicado variabilidade do caráter dentro da espécie e herança quantitativa (KURODA, 1981; MATTA, 2005). Para 
utilização eficiente da resistência genética no desenvolvimento de variedades que apresentem resistência duradoura e ampla, é necessário tanto o conhecimento das fontes de resistência na espécie hospedeira como da variabilidade da agressividade na população do patógeno.

A utilização de cultivares resistentes é uma alternativa simples e eficiente no controle de doenças causadas por bactérias. Recentemente, vários trabalhos com melhoramento de plantas de maracujazeiro visando à resistência à bacteriose têm sido realizados no País (EMBRAPA, 2014).

\subsection{Aspectos relacionados a produtividade e qualidade dos frutos}

Segundo BARBOSA (1998), programas de melhoramento genético tem sido conduzidos visando à obtenção de variedades mais produtivas e resistentes a doenças. Entretanto, atender as exigências de mercado, interno e externo, e a redução dos custos de produção também são fatores essenciais para o ganho de mercado da cultura.

O melhoramento genético deve visar um melhor desempenho na produção e produtividade do maracujazeiro, com a obtenção de frutos com padrão de qualidade quanto ao sabor, acidez, tamanho dos frutos, vigor e rendimento de suco, como também, a resistência a doenças (MELETTI \& BRUCKNER, 2001).

Visando a atender as exigências de mercado, a qualidade dos frutos é fator importante no melhoramento do maracujazeiro. No entanto, o conceito de qualidade de frutos pode variar bastante dependendo das características importantes a serem atendidas no decorrer do tempo, sendo um ponto muito dinâmico (GRECO, 2014).

Em termos de qualidade considera-se que uma variedade desenvolvida para 0 mercado in natura deve apresentar frutos grandes e ovais, cavidade interna completamente preenchida, visando uma boa classificação comercial, ser resistente ao transporte e a perda de qualidade durante armazenamento e comercialização. Se a produção for voltada para indústria, é necessário ter casca fina, apresentar cavidade interna completamente preenchida, conferindo alto rendimento de suco, possuir polpa com coloração amarelo-dourada estável e alto teor de sólidos solúveis, superior a $13^{\circ}$ Brix (OLIVEIRA et al., 1994; BRUCKNER et al., 2002).

Segundo RANGEL (2002), a classificação do tamanho do fruto pode ser feita através do diâmetro equatorial: Primeira - frutos com diâmetro equatorial igual ou menor 
que $55 \mathrm{~mm}$; 1B - igual ou maior que 55 até $65 \mathrm{~mm}$; 1A - Igual ou maior que 65 até 75 $\mathrm{mm} ; 2 \mathrm{~A}$ - igual ou maior que 75 até $90 \mathrm{~mm}, 3 \mathrm{~A}$ - maior que $90 \mathrm{~mm}$.

Frutos de primeira e 1B são frutos considerados ideais para a indústria, pois não são aceitos nos mercados in natura devido ao reduzido tamanho. As demais classes $1 \mathrm{~A}$, 2A e 3A são destinadas aos mercados comerciais de fruta fresca (COIMBRA, 2010).

\subsection{Características físico-químicas dos frutos na pós-colheita}

Por se tratar de um fruto climatérico, apresentando amadurecimento após a colheita, adquirindo cor, textura e doçura superior, o maracujá apresenta durante seu desenvolvimento diversas transformações fisiológicas que alteram suas características físico-químicas.

A coloração do fruto, assim como outras características externas do maracujá, são as principais características avaliadas pelo consumidor, portanto, devem atender a certos padrões para que atinjam a qualidade desejada na comercialização (NASCIMENTO, 1999). Esse critério também é usado pelo produtor como indicador do momento de colheita, pois essas mudanças de cor refletem as alterações físico-químicas que acompanham o processo de seu amadurecimento. Geralmente, o fruto é colhido após sua abscisão, quando apresenta amadurecimento completo, o que aumentam as perdas devido à contaminação por microrganismos e desidratação, aumentando a perecibilidade e reduzindo o período de conservação pós-colheita do fruto (MARCHI et al., 2000; SALOMÃO, 2002).

Alguns fatores interferem diretamente na qualidade do maracujá, entre eles, a época de produção, condições edafoclimáticas, tipo de condução, variabilidade genética da espécie, estádio de maturação na colheita, tempo de armazenamento, temperatura, embalagem de armazenamento, dentre outros (NASCIMENTO et al., 1998; GAMARRA ROJAS \& MEDINA, 1996; SILVA \& OLIVEIRA, 2001; LUZ et al., 2002; ARJONA et al., 1992).

A determinação de umidade é uma das medidas mais importante e utilizada na análise de alimentos, porém, sua determinação precisa é muito difícil. A água ocorre nos alimentos de três diferentes maneiras: água livre, água disponível e água ligada. Os frutos são alimentos que apresentam elevados teores de umidade, e por isso, estão sujeitos a sofrer inúmeras alterações uma vez que a água é o principal veículo para o processamento de alterações de natureza bioquímica e química nos alimentos (CHAVES, 2004). A 
umidade de um alimento está relacionada com sua qualidade e composição, e pode afetar o armazenamento, embalagens e processamento.

Segundo SILVA et al., (2002), o teor de sólidos solúveis totais (SST), expresso como percentagem do peso da matéria fresca, apresenta alta correlação positiva com o teor de açúcares e, portanto, geralmente é aceito como uma importante característica de qualidade. O teor de SST é utilizado na agroindústria, para intensificar o controle da qualidade do produto final, controle de processos e ingredientes (CHAVES, 2004). Os sólidos solúveis totais ( ${ }^{\circ}$ Brix) são usados como índice de maturidade para alguns frutos, e indicam a quantidade de substâncias que se encontram dissolvidos no suco, constituído na sua maioria por açúcares. O maracujá azedo disponível no mercado tem apresentado sólidos solúveis totais entre 13 e $18^{\circ}$ Brix, peso entre 50 e 130 g, e máximo de $36 \%$ de rendimento de suco (RUGGIERO et al., 1996).

De acordo com CHAVES (2004), as cinzas são consideradas como medida geral de qualidade e, frequentemente, são utilizadas como critério na identificação dos alimentos. As cinzas em alimentos referem ao resíduo inorgânico remanescente da queima da matéria orgânica, sem resíduo de carvão, sendo compostas por grandes quantidades de potássio, sódio, cálcio e magnésio, pequenas quantidades de ferro, alumínio, cobre, manganês e zinco e por traços de outros elementos. É importante observar que a composição das cinzas corresponde à quantidade de substâncias minerais presentes nos alimentos, devido às perdas por volatilização ou mesmo pela reação entre os componentes.

Entre as principais características físicas consideradas para as frutas estão o tamanho, a forma (diâmetro: comprimento), espessura da casca e o número de sementes, o peso, a textura, a relação polpa/casca e o rendimento em suco ou polpa (CHITARRA \& CHITARRA, 2005).

O fruto do maracujazeiro possui coloração amarelo-canário, rósea e arroxeada brilhante e apresenta mesocarpo variando entre 0,5 e $4 \mathrm{~cm}$. A composição física da fruta é basicamente: $52 \%$ de casca, $34 \%$ de suco e $14 \%$ de sementes. O suco é o principal produto, entretanto já há utilização para as sementes e a casca (DURIGAN \& DURIGAN, 2002; DANTAS, 2009).

Conforme MANICA (1997), as sementes possuem forma oval achatada, com 5 a $6 \mathrm{~mm}$ de comprimento por 3 a $4 \mathrm{~mm}$ de largura, coloração pardo-escuras, com aspecto reticulado e recobertas por pontuações mais claras quando completamente secas. Os 
frutos das espécies cultivadas possuem entre 200 a 300 sementes no seu interior, o que representa de 4,6 \% a 13,7 \% em relação ao seu peso total (SOUSA, 2005). O número de sementes está diretamente associado ao rendimento de suco, visto que as mesmas são envolvidas pela sarcotesta ou arilo, local onde se encontra o suco do maracujá (RUGGIERO, 1998).

As características desejadas no fruto variam de acordo com a finalidade para que o mesmo se destina. Para o consumo in natura preferem-se frutos de boa aparência, maior tamanho, mais doces e menos ácidos, já para indústria é preferível frutos com rendimento de suco com alto teor de sólidos solúveis totais. Segundo NASCIMENTO (1999), altos teores de ácidos no suco revelam uma característica importante no que diz respeito ao processamento, pois é de interesse que os frutos possuam uma elevada acidez, uma vez que este fator aumenta o rendimento. 


\section{REFERÊNCIAS BIBLIOGRÁFICAS}

ALFENAS, P.F.; BRAZ, A.S.K.; TORRES, L.B.; SANTANA, E.; NASCIMENTO, V.S.; CARVALHO, M.G.; OTONI, W.C.; ZERBINI, F.M. Transgenic passion fruit expressing RNA derived from Cowpea aphid-borne mosaic virus is resistant to passion fruit woodiness disease. Fitopatologia Brasileira, v.30, p.33- 38, 2005.

ARJONA, H. E.; MATA, F. B. Postharvest quality of passion fruit as influenced by harvest ethylene treatment. HortScience, Alexandria, n.10, P.1297-1298, Oct. 1991.

BARBOSA, L.V. Citologia de híbridos somáticos de Passiflora spp obtidos por fusão de protoplastos. Universidade de São Paulo, Piracicaba, 1998. 97p. Tese Doutorado.

BELLON, G. Filogenia, variabilidade genética e caracterização de Passifloras silvestres, comerciais e híbridos interespecíficos como fontes de resistência à doenças. Brasília: Faculdade de Agronomia e Medicina Veterinária, Universidade de Brasília, 2014, 151 p. Tese de Doutorado.

BRUCKNER, C.H.; MELETTI, L.M.M.; OTONI, W.C.; ZERBINI JÚNIOR, F.M. Maracujazeiro. In: Bruckner, C.H. (ed.). Melhoramento de Fruteiras Tropicais. Viçosa: UFV, 2002. Cap. 13. p. 373-410.

BRUCKNER, C.H.; OTONI, W.C. Hibridação em maracujá. In: BORÉM, A. (Ed.) Hibridação artificial de plantas. Viçosa: UFV, 1999. p. 379-399.

BRUCKNER, C.H.; SUASSUNA, T.M.F.; RÊGO, M.M.; NUNES, E.S. Autoincompatibilidade do maracujá: implicações no melhoramento genético. In: Faleiro, F.G.; Junqueira, N.T.V.; Braga, M.F. (Eds.) Maracujá: germoplasma e melhoramento genético. Planaltina, DF: Embrapa Cerrados, 2005. p. 317-338.

CAVICHIOLI, J. C. de; RUGGIERO, C.; VOLPE, A.; PAULO, E. M.; FAGUNDES, J. L.; KASAI, F. S. Florescimento e frutificação do maracujazeiro- amarelo submetido à iluminação artificial, irrigação e sombreamento. Revista Brasileira de Fruticultura, Jaboticabal, v. 28, n.1, p. 92-96, 2006.

CERQUEIRA-SILVA C.B, MOREIRA C.N, FIGUEIRA A.R, CORRÊA R.X, OLIVEIRA A.C. Detection of a resistance gradient to Passion fruit woodiness virus and selection of 'yellow' passion fruit plants under field conditions. Genetics and Molecular Research ISSN- 1675680- p.1209-1216 (2008).

CHAVES, M. C. V.; GOUVEIA, J. P. G de; AlMEIDA, F. A. C.; LEITE, J. C. A.; SILVA, F. L. H. da. Caracterização físico-química do suco da acerola. Revista de Biologia \& Ciências da Terra, 2004. Universidade Estadual da Paraíba. PB. Disponível em: <http://eduep.uepb.edu.br/rbct/sumarios/pdf/acerola.pdf $>$ Acesso em: abril de 2009.

CHITARRA, M. I. F.; CHITARRA, A. B. Pós-colheita de frutos e hortaliças: fisiologia e manuseio. 2. ed. rev. e ampl. Lavras: UFLA, 2005. 
CIVEROLO, E. L.; HATTING, M. J. Xanthomonas cmpestris pv pruni: Cause of Prunus Bacterial Spot. In: SWINGS, J. G.; CIVEROLO, E. L. Xanthomonas. London, Chapman \& Hall, 1993. 339p.

COBB, N. A. Woodiness of the passionfruit. Agric. Gaz. N. S. W. 12: 407-418, 1901. In: KITAJIMA, E. W.; CHAGAS, C. M. e CRESTANI, O. A. Enfermidades de etiologia viral e associadas a organismos do tipo micoplasma em maracujazeiros no Brasil. Fitopatologia Brasileira, 11: 409-432, 1986.

COIMBRA, K. G.; Desempenho agronômico de progênies de maracujazeiro-azedo no Distrito Federal. Faculdade de Agronomia e Medicina Veterinária, Universidade de Brasília-Brasília, 2010; 125p. Dissertação de Mestrado.

COSTA, J. G. C. da; RAVA, C. A.; SARTORATO, A. Incorporação de alelos que condicionam resistência ao fungo da antracnose em duas cultivares de feijoeiro comum: avaliação das linhagens quanto ao rendimento, características agronômicas e reação a doenças. Summa Phytopathologica, Jaboticabal, v. 22, n. 1, p. 26-32, jan. 1996.

CUNHA, M. A. P. (Org.) Maracujá: produção e qualidade na passicultura. Cruz das Almas: Embrapa Mandioca e Fruticultura, 2004. p. 14-35.

CUNHA, M.A.P.; BARBOSA, L.V.; JUNQUEIRA, N.T.V. Espécies de maracujazeiro. In: LIMA, A.A. (Ed.) Maracujá produção: aspectos técnicos. Brasília: Embrapa Informação Tecnológica, 2002. 104 p. Embrapa Informação Tecnológica. Frutas do Brasil, n. 15.

DANTAS, A. M. T. Características físicas e físico-químicas de frutos de genótipos de maracujazeiro-azedo cultivados em diferentes épocas de colheita, no Distrito Federal. Brasília: Faculdade de Agronomia e Medicina Veterinária, Universidade de Brasília, 2009, 100p. Dissertação de Mestrado.

DIAS, S. C. Morte precoce do maracujazeiro-amarelo (Passiflora edulis f. flavicarpa) causada por patógenos que afetam a parte aérea da planta. Dissertação (Mestrado em Fitopatologia) - Universidade de Brasília, Brasília, 1990. 137p.

DIAS, S. C.; TAKATSU, A. Ocorrência de bacteriose do maracujazeiro (Passiflora sp.) causada por Xanthomonas campestris pv. passiflorae no Distrito Federal. Fitopatologia Brasileira, v.12, n.2, p. 140, 1987. Dye et al, (1980).

DURIGAN, J. F.; DURIGAN, M. F. B. Características dos Frutos. In: MATSUURA, F. C. A. U., FOLEGATTI, M. I. S. (eds) Frutas do Brasil 23, 1 eds., chap. 2, Brasilia: Embrapa Informacao Tecnologica, 2002.

EMBRAPA. Pesquisadores preparam dez novas cultivares de maracujá. Dispinível em: < https://www.embrapa.br/busca-de-noticias/-/noticia/1961787/pesquisadores-preparamdez-novas-cultivares-de-maracuja > Acesso: Novembro de 2015.

FALEIRO, F.G.; JUNQUEIRA, N.T.V.; BRAGA, M.F. Germoplasma e melhoramento genético do germoplasma - desafio da pesquisa. In: FALEIRO, F.G.; JUNQUEIRA, 
N.T.V.; BRAGA, M.F. (Ed.) Maracujá germoplasma e melhoramento genético. Brasília, DF: Embrapa Cerrados, 2005. p. 187-210.

FALEIRO, F. G.; JUNQUEIRA, N. T. V.; FÁVERO, A. P.; LOPES, M. A. Prémelhoramento de plantas: experiências de sucesso. In: FALEIRO, F. G.; NETO, A. L. F.; JÚNIOR, W. Q. R. Pré-melhoramento, melhoramento e pós melhoramento: estratégias e desafios. Planaltina, DF: Embrapa Cerrados; Brasília DF: Embrapa Informação Tecnológica, 2008.

FALEIRO, F.G.; JUNQUEIRA, N.T.V. Recursos genéticos: conservação, caracterização e uso. In: FALEIRO, F.G.; ANDRADE, S.R.M.; REIS JÚNIOR, F.B. Biotecnologia: estado da arte e aplicações na agropecuária. Planaltina, DF: Embrapa Cerrados, 2011a. p. 513-551.

FALEIRO, F.G., F, JUNQUEIRA N T V., BRAGA, M.F., OLIVEIRA, E. J. e., PEIXOTO, J.R., COSTA, A.M. Germoplasma e melhoramento genético do maracujazeiro: histórico e perspectivas Planaltina, DF: Embrapa Cerrados, 2011b.36 p.ISSN 1517-5111; ISSN Online 2176-5081;307).

FERRAZ, J. V.; LOT, L. Fruta para consumo in natura tem boas perspectivas de renda. In: AGRIANUAL 2007: Anuário estatístico da agricultura brasileira. São Paulo: FNP, 2007. p.387-394.

GAMARRA, R.; G.; MEDINA, V M. (1995). Variações físico-químicas do maracujá ácido em função da idade do fruto. Revista Brasileira de Fruticultura. Cruz das Almas, v.17, n.3, p. 103110, 1996.

GIORIA, R. Viroses do maracujazeiro: incidência na Alta Pauilista, SP, danos causados pelo "passion fruit woodness virus" (PWV) e sintomatologia do " cucumber mosaic virus" (CMV). Piracicaba, SP: ESALQ, 1999. 67p. (Dissertação de Mestrado).

GIORIA, R.; BOSQUÊ, G.G.; REZENDE, J.A.M.; AMORIM, L.; KITAJIMA, E.W. Incidência de viroses de maracujazeiro na Alta Paulista - SP, e danos causados pelo "Passion fruit woodiness virus". Fitopatologia Brasileira, Brasília, v.25, p.182-189, 2000 .

GONÇALVES, E. R.; ROSATO, Y. B. Genotypic characterization of Xanthomonad stains isolated from passion fruit plants (Passiflora spp.) and their relatedness to different Xanthomonas species. Internacional Journal of Systematic and Evolutionary Microbiology, v.50, p.811-821, 2000.

GRECO, S.M.L. Caracterização físico-química e molecular de genótipos de maracujá azedo cultivados no Distrito Federal. Faculdade de Agronomia e Medicina Veterinária, Universidade de Brasília-Brasília, 2014; 149p. Tese de Doutorado.

HALFELD-VIEIRA, B. A.; NECHET, K. L. Mancha-bacteriana do maracujá: sintomas, danos e medidas de controle. Boa Vista: Embrapa Roraima, 2006a. 4 p. (Embrapa Roraima. Comunicado técnico, 03). 
IBGE - INSTITUTO BRASILEIRO DE GEOGRARIA E ESTATÍSTICA. Maracujá: área plantada e quantidade produzida. Brasília-DF. Disponível em: http://www.ibge.gov.br>. Acesso em: outubro de 2015.

INSTITUTO ADOLFO LUTZ. Métodos Físico-Químicos para Análise de Alimentos. 4a ed., $1^{\circ}$ Ed. Digital, v.1, São Paulo - SP, 2008, 1020p.

JUNQUEIRA, N. T. V.; BRAGA, M. F.; FALEIRO, F. G.; PEIXOTO, J. R.; BERNACCI, L. C. Potencial de espécies silvestres de maracujazeiro como fonte de resistência a doenças. In: FALEIRO, F. G.; JUNQUEIRA, N. T. V.; BRAGA, M. F. Maracujá: germoplasma e melhoramento genético. Planaltina, DF: Embrapa Cerrados, 2005. p. 81-106.

KIMATI, H.; AMORIM, L.; BERGAMIM FILHO, A.; CAMARGO, L. E. A., REZENDE, A.M. Manual de Fitopatologia- Doenças das plantas cultivadas - v. 2, 3 ed. Editora Agronômica Ceres Ltda. São Paulo, 1997, 774p, 525-534p.

KIMATI, H.; AMORIM, L.; REZENDE, J. A. M.; BERGAMIM FILHO, A. \& CAMARGO, L. E. A. (Ed.). Manual de fitopatologia. Doenças de plantas cultivadas. 4 eds. São Paulo: Agronomia Ceres, v.2, 2005.

KIMATI, H; AMORIM, L.; REZENDE, J.A.M.; BERGAMIN FILHO, A.; CAMARGO, L. E. A. Manual de Fitopatologia. 4 ed. São Paulo: Agronomica Ceres, 2005, v2.

KITAJIMA, E.W., CHAGAS, C.M. e CRESTANI, O.A. Enfermidades de etiologia viral e associadas a organismos do tipo micoplasma em maracujazeiro no Brasil. Fitopatologia Brasileira 11:409-432. 1986

KURODA, N.H. Avaliação do comportamento quanto à resistência de espécies e progênies de maracujazeiro a Xanthomonas passiflorae. 1981. 45p (Trabalho de conclusão de Curso) -Faculdade de Ciências Agrárias e Veterinária, Jaboticabal

LIMA, L. M.; ROSWALKA, L. C. Manejo integrado de doenças de fruteiras. Lavras: UFLA, 2007. 1 CD-ROM.

LUZ, J. M. A.; MELO, B. de; BUSO FILHO, J. V; SILVA, J. R. da; MARQUES, S. B. Propriedades físico-químicas de frutos de maracujá amarelo produzidos em sistema de espaldeira e latada. In: CONGRESSO BRASILEIRO DE FRUTICULTURA, 16., 2002, CD-ROM. Belém. Anais. Belém: Brasileira de Fruticultura, 2002.

MANICA, I. Botânica e variedades. In: MANICA, I. (Ed.). Fruticultura tropical: maracujá. São Paulo: Agronômica Ceres, 1981. 160p.

MANICA, I. Maracujazeiro: Taxionomia-anatomia-morfologia. In: Maracujá: Temas selecionados 1) melhoramento, morte prematura, polinização, taxionomia. Porto Alegre: Cinco Continentes, 1997.p.7-24.

MARCHI, R. de; MONTEIRO, M.; BENATO, E. A; SILVA, C. A. R. da. Uso da cor da casca como indicadorde qualidade do maracujá amarelo (Passiflora edulis Sims. f. 
flavicarpa Deg) destinado à industrialização. Ciência e Tecnologia de Alimentos, set/dez. 2000, v. 20, n. 3, p. $231-287$.

MATTA, F.P. Mapeamento de QRL para Xanthomonas axonopodis pv. passiflorae em maracujá-amarelo (Passiflora edulis Sims f. flavicarpa Deg. ). 2005. 230f. Tese (Doutorado em Genética e Melhoramento de Plantas) Escola Superior de Agricultura "Luís de Queiroz “-Universidade de São Paulo, Piracicaba.

MEDEIROS, S. A. F. de. Desempenho agronômico e caracterização físico-quimica de génotipos de maracujá-roxo e maracujá-amarelo no Distrito Federal. 2005. $95 \mathrm{f}$. Dissertação (Mestrado em Agronomia) - Universidade de Brasília, Brasília, DF, 2005.

MELETTI L. M. M. \& BRUCKNER, C.H. Melhoramento genético. In: BRUCKNER, C. H. \& PICANÇO, M. C. (Eds.). Maracujá: tecnologia de produção, pós-colheita, agroindústria, Mercado. Porto Alegre: Cinco Continentes. p. 345-385. 2001.

MELETTI, L.M.M.; SOARES-SCOTT, M.D.; BERNACCI, L.C.; PASSOS, I.R.S. Melhoramento genético do maracujá: passado e futuro. In: Faleiro, F.G.; Junqueira, N.T.V.; Braga, M.F. (Eds.) Maracujá: germoplasma e melhoramento genético. Planaltina, DF: Embrapa Cerrados, 2005. p. 55-78.

MELO, K. T. Comportamento de seis cultivares de maracujazeiro- amarelo (Passiflora edulis Sims f. flavicarpa Deg.) em Vargem Bonita, no Distrito Federal. 1999. 75f. Dissertação (Mestrado em Agronomia) - Faculdade de Agronomia e Medicina Veterinária, Universidade de Brasília, Brasília, 1999.

MIRANDA, H.A. Incidência e severidade de Xanthomonas axonopodis pv. passiflorae, Colletotrichum gloeosporioides, Septoria passiflorae, Cladosporium herbarum e passion fruit woodiness virus em genótipos de maracujazeiro azedo cultivados no Distrito Federal. Brasília, 2004. 87f. Dissertação (Mestrado em Ciências Agrárias) - Faculdade de Agronomia e Medicina Veterinária, Universidade de Brasília, 2004.

NASCIMENTO, A.V., SANTANA, E.N., BRAZ, A.S., ALFENAS, P.F., PIO-RIBEIRO, G., ANDRADE, G.P., DE CARVALHO, M.G., ZERBINI, F.M. (2006). Cowpea aphidborne mosaic virus (CABMV) is widespread in passionfruit in Brazil and causes passionfruit woodiness disease. Archives of virology, 151(9):1797-809.

NASCIMENTO, A.V.S., SOUZA, A.R.R., ALFENAS, P.S., ANDRADE, G.P., CARVALHO, M.G., PIO-RIBEIRO, G., ZERBINI, F.M. (2004) Análise filogenética de potyvirus causando endurecimento dos frutos do maracujazeiro no Nordeste do Brasil. Fitopatologia Brasileira, 29(4):378-383.

NASCIMENTO, T. B. do; RAMOS, J. D.; MENEZES, J. B. Características físicoquímicas do maracujá amarelo produzido em diferentes épocas. Revista Brasileira de Fruticultura, Jaboticabal, v. 2, n. 1, p. 59-63, 1999. 
NASCIMENTO, T. B. do; RAMOS, J. D.; MENEZES, J. B. Características físicoquímicas do maracujá amarelo (Passiflora edulis f. flavicarpa Deneger) produzido em diferentes épocas. Revista Brasileira de Fruticultura, Cruz das Almas, v. 20, n. 1, p. 33-38, abr. 1998.

NEGREIROS, J. R. S.; JUNIOR, A. W.; ALVARES, V. S.; SILVA, J. O. C.; NUNES, E. S.; ALEXANDRE, R. S.; PIMENTEL, L. D.; BRUCKNER, C. H. Influência do estádio de maturação e do armazenamento pós-colheita na germinação e desenvolvimento inicial do maracujazeiro-amarelo. Revista Brasileira de Fruticultura, 28(1), p. 21-24, 2006.

OLIVEIRA, J.C. de; NAKAMURA, K.; MAURO, A. O.; CENTURION, M.A.P. da C. Aspectos gerais do melhoramento do maracujazeiro. In: São José, A.R. Maracujá, produção e mercado. Vitória da Conquista: DFZ-UESB, 1994. P. 27-37.

PEREIRA, A. L. G. Uma nova doença bacteriana do maracujá (Passiflora edulis, Sims) causada por Xanthomonas passiflorae n. sp. Arquivos do Instituto Biológico, v. 36, n.4, p.163-174. 1969.

PIMENTEL, L.D., STENZEL, M.N.C., CRUZ, C.D., BRUCKNER, C.H.. Seleção precoce de maracujazeiro pelo uso da correlação entre dados de produção mensal e anual. Pesquisa Agropecuária Brasileira, 43:1303-1309, 2008.

PIO RIBEIRO, G.; MARIANO, R. de L.R.D. Doenças do maracujazeiro (Passiflora spp.) In: KIMATI, L.; AMORIM, L.; BERGAMIN FILHO, A.; CAMARGO, I.E.A.; REZENDE, J.A. (ed.) Manual de fitopatologia: doenças das plantas cultivadas. 3. ed. São Paulo: Agronômica Ceres,1997.v.2,p.525-534.

RANGEL, L. E. P. Desempenho agronômico de nove genótipos de maracujazeiro amarelo cultivados sob três níveis de adubação potássico no Distrito Federal. Brasília, Universidade de Brasília, 2002. 45p. Dissertação de Mestrado.

REVISTA CAMPO E NEGÓCIO. Avanços do cultivo do maracujá no Brasil. Disponível em: $<\underline{\text { http://www.revistacampoenegocios.com.br/avancos-no-cultivo-de-maracuja- }}$ no-brasil/> Acesso: Novembro de 2015.

REZENDE, J.A.M. Doenças de vírus e micoplasma do maracujazeiro no Brasil. In: SÃO JOSÉ, A.R. (Ed.). Maracujá, produção e mercado. Vitória da Conquista, BA, DFZ, UESB, 1994. p. 116-125.

REZENDE, J.A.M. Práticas culturais para prevenção e convivência com as viroses do maracujazeiro. In: SAMPAIO, A.C.; FUMIS, T.F.; ROSSI, A.D.; ALMEIDA, A.M.; GARCIA, M.J.M. (Ed.). Manejo no controle do vírus do endurecimento dos frutos (PWV) do maracujazeiro. Jaboticabal: Multipress, 2006. p.47-58.

RUGGIERO, C. Situação da cultura do maracujazeiro no Brasil. Informe Agropecuário, v.21, n.206, p 5-9, 2000. 
RUGGIERO, C.; SÃO JOSÉ, A. R.; VOLPE, C. A.; OLIVEIRA, J. C. de; DURIGAN, J. F.; BAUMGARTNER, J. G.; SILVA, J. K.; NAKAMURA, K.; FERREIRA, M. E.; KAVATI, R.; PEREIRA, V. de P. Maracujá para exportação: aspectos técnicos da produção. Brasília: EMBRAPA, 1996. 64p. (Série FRUTPEX, 19).

SALOMÃO, L. C. C. Colheita. Maracujá. Pós-colheita. Brasília: Embrapa Informação Tecnológica, 2002. 51 p. Frutas do Brasil, 23.

SANTOS, C.C.F.; Santos Filho, H.P. Doenças causadas por bactérias. In: Santos Filho, H.P.; Junqueira, N.T.V. (Ed.). Maracujá: fitossanidade. Brasília: Embrapa informação Tecnológica, 2003. n.32, p.22-24.

SILVA, J. R.; OLIVEIRA, H. J. de O. Implantação da cultura, manejo e tratos culturais. In: BRUCKNER, C. H.; PICANÇO, M. C. Maracujá: tecnologia de produção, póscolheita, agroindústria, mercado. Porto Alegre: Cinco Continentes, 2001.

SILVA, P. S. L.; SÁ, W. R.; MARIGUELLE, K. H.; BARBOSA, A. P. R.; OLIVEIRA, $O$. F. Sólidos solúveis totais em frutos de espécies de clima temperado. Mossorá, RN. 2002 .

SITHOLE-NIANG, I.; NYATHI, T.; MAXWELL, D.P.; CANDRESSE, T. Sequence of the 3 '- terminal of a Zimbabwe isolate of Cowpea aphid- borne mosaic virus (CABMV). Archives of Virology, v.141, p. 935-943. 1996.

SOUSA, M. A. F. Avaliação da produtividade, incidência e severidade de doenças em frutos de 17 genótipos de maracujazeiro-amarelo, cultivados no Distrito Federal. Brasília, Faculdade de Agronomia e Medicina Veterinária, Universidade de Brasília; 2005, 120p. Dissertação de Mestrado.

VAN REGENMORTEL, M.H.V., FAUQUET, C.M., BISHOP, D.H.L., CARSTENS, E., ESTES, M.K., LEMON, S., MANILOFF, J., MAYO, J.A., McGEOCH, D.J., PRINGLE, C.R. e WICKNER, R. (Eds.) Virus taxonomy. Classification and nomenclature of viruses. Seventh report of the International Committee on the Taxonomy of Viruses. New York: Academic Press. 2000.

VIANA, F. M. P.; FREIRE, F. C. O.; CARDOSO, J. E.; VIDAL, J. C. Principais doenças do maracujazeiro na Região Nordeste e seu controle. Fortaleza: Embrapa Agroindústria Tropical, 2003. 12 p. (Embrapa Agroindústria Tropical. Comunicado técnico, 86)

VILELA, M.S. Diversidade genética, produtividade e reação de progênies de maracujazeiro à doenças sob condições de campo. Faculdade de Agronomia e Medicina Veterinária, Universidade de Brasília-Brasília, 2013; 183 p. Tese de Doutorado.

VILlANOVA, A. C. C.; SILVA, D. G.P. D.; CASTIGLIONI, G. L.; JUNQUEIRA, N. T.V.; BRAGA, M. F.; SANTOS, E. C. dos.; SOBRAL, L.; LIMA, C. A. D. Transmissão via semente da virose do Endurecimento do Fruto e da bacteriose do maracujazeiro. XL Congresso Brasileiro de Fitopatologia. Maringá-Paraná. Vol. 32, Suplemento, ISSN 01004158. p. 312, 2007. 


\section{CAPÍTULO 1}

AVALIAÇÃO DA SEVERIDADE E INCIDÊNCIA DE XANTHOMONAS AXONOPODIS PV. PASSIFLORAE E SEVERIDADE DE COWPEA APHID-BORNE MOSAIC VIRUS (CABMV) EM PROGÊNIES DE MARACUJÁ AZEDO SOB CASA DE VEGETAÇÃO 
AVALIAÇÃO DA SEVERIDADE E INCIDÊNCIA DE XANTHOMONAS AXONOPODIS PV. PASSIFLORAE E SEVERIDADE DE COWPEA APHID-BORNE MOSAIC VIRUS (CABMV) EM PROGÊNIES DE MARACUJÁ AZEDO SOB CASA DE VEGETAÇÃO

\section{RESUMO}

O maracujazeiro é atacado por diversos patógenos, entre eles Xanthomonas axonopodis pv. passiflorae, causadora da mancha oleosa e Cowpea aphid-borne mosaic virus (CABMV), causador da virose do endurecimento dos frutos do maracujazeiro. Este estudo teve como objetivo analisar a reação de progênies de maracujá azedo à CABMV e à Xanthomonas axonopodis pv. passiflorae sob condições de casa de vegetação. Foi utilizado o delineamento de blocos casualizados com parcelas subdivididas, consistindo de 4 repetições e 5 plantas por parcela, testando-se 10 progênies, em 6 épocas de avaliação. O isolado de CABMV foi inoculado mecanicamente em três folhas de cada planta por meio defricção das partes superiores das folhas com extrato vegetal obtido por meio de maceração do material foliar infectado com o vírus CABMV. A severidade da virose do endurecimento dos frutos foi avaliada de acordo com uma escala de notas de 1 a 4. A inoculação da suspensão bacteriana nas plantas foi realizada por meio do método da agulha, utilizando o isolado UnB 1393, na concentração 1 x $10^{6} \mathrm{UFC} / \mathrm{mL}$. Foram avaliadas a incidência e a severidade da mancha oleosa utilizando-se uma escala com notas entre 0 e 5 . As avaliações foram realizadas com intervalos de 7 dias, logo após o aparecimento dos primeiros sintomas da doença. Foram encontradas diferenças significativas entre as progênies quanto à incidência e à severidade das doenças. As progênies com menor severidade à virose do endurecimento dos frutos foram as Rosa Intenso, MSCA e EC3-0. Dos 10 materiais analisados, 9 foram classificados como moderadamente suscetível e 1, progênie MAR 20\#24 pl. 2, como suscetível à virose em casa de vegetação. As avaliações da mancha oleosa mostraram que as progênies Gigante Amarelo pl. 1, Rosa Intenso e MAR20\#24 pl. 2 apresentaram as menores severidades e incidências na folha. Os materiais Rubi Gigante, MAR 20\#21 e MAR 20\#41 apresentaram os piores índices para as mesmas análises. Nove das progênies foram consideradas suscetível, e apenas 1, progênie Rosa Intenso, como moderadamente suscetível à bacteriose em casa de vegetação. A progênie Rosa Intenso destacou-se para 
ambos os patógenos, sendo a mais promissora para uso em programas de melhoramento genético visando resistência múltipla a doenças do maracujazeiro.

Palavras-chaves: Passiflora edulis Sims, resistência, Cowpea aphid-borne mosaic virus, Xanthomonas axonopodis pv. passiflorae, melhoramento genético. 
SEVERITY AND INCIDENCE EVALUATIONS OF XANTHOMONAS AXONOPODIS PV. PASSIFLORAE AND SEVERITY EVALUATION OF COWPEA APHID-BORNE MOSAIC VIRUS IN YELLOW PASSION FRUIT UNDER GREENHOUSE CONDITIONS

\begin{abstract}
Passion fruit crop is infected by many plant pathogens, such as Xanthomonas axonopodis pv. passiflorae, causal agent of the bacterial spot and Cowpea aphid-borne mosaic virus
\end{abstract} (CABMV), which causes the passion fruit woodiness disease (PWD). The objective of this study was to evaluate the reaction of yellow passion fruit progenies to Xanthomonas axonopodis pv. passiflorae and CABMV, under greenhouse conditions. The experiment consisted of a randomized block design with subdivided parcels comprised of ten treatments (progenies), four repetitions, five replications per progeny and six evaluation times. CABMV isolate was mechanically inoculated in three leaves per plant by light friction of the adaxial foliar limbs with a vegetable extract obtained from the maceration of leaves of yellow passion fruit showing symptoms of CABMV infection. PWD severity was evaluated according to a 1 to 4 scale. Bacterial suspension inoculation was performed through the needle method, using the UnB 1393 strain, at $1 \times 10^{6} \mathrm{UFC} \mathrm{mL}^{-1}$. Bacterial spot incidence and severity were evaluated using a 0 to 5 scale. Disease incidence and severity were recorded at a 7-day interval after disease symptoms have appeared. Progenies differed for disease incidence and severity. Rosa Intenso, MSCA, and EC3-0 were the progenies with lowest PWD severity. Nine progenies were classified as moderately susceptible to PWD under greenhouse conditions and only MAR 20\#24 pl. 2 was classified as susceptible. Bacterial spot disease evaluations showed that Gigante Amarelo pl. 1, Rosa Intenso, and MAR 20\#24 pl. 2 presented the lowest disease severity and incidence. Progenies Rubi Gigante, MAR 20\#21, and MAR20\#41 showed the highest indexes for the same evaluations. Nine progenies were classified as susceptible and only Rosa Intenso was classified as moderately susceptible to the bacterial spot disease, under greenhouse conditions. Rosa Intenso stood out as the most promising progeny to both plant pathogen tested, and to be used in passion fruit breeding programs focusing on multiple disease resistance. 
Keywords: Passiflora edulis Sims, resistance, Cowpea aphid-borne mosaic virus, Xanthomonas axonopodis pv. passiflorae, genetic breeding 


\section{INTRODUÇÃO}

O maracujá tem adquirido grande importância no contexto mundial, notadamente a partir das últimas três décadas, sendo que o Brasil ocupa uma situação de destaque como maior produtor e consumidor mundial da fruta (FALEIRO et al., 2008).

Segundo dados preliminares do IBGE, foram colhidas mais de 510.000 toneladas em uma área de 41.500 ha no decorrer da safra 2013/2014, apresentando uma queda de $15 \%$ em relação à safra 2012/13 (REVISTA CAMPO E NEGÓCIO 2015). A produtividade média brasileira é estimada em 13,42 toneladas ha/ano, entretanto, o potencial da cultura pode chegar a 50 toneladas ha/ano, através da utilização de cultivares geneticamente melhoradas e tecnologias adequadas no sistema de produção (FALEIRO et al., 2011).

Nos últimos anos, a produção nacional foi insuficiente para abastecer o consumo interno do Brasil, havendo necessidade de importação de polpa de outros países para abastecer a indústria de sucos nacional (COSTA \& COSTA, 2005; FERRAZ \& LOT, 2007).

O melhoramento genético deve visar um melhor desempenho agronômico do maracujá, com a obtenção de plantas vigorosas, frutos com padrão de qualidade superior, considerando sabor, acidez, tamanho e rendimento de suco e resistência a doenças, sem deixar de atender as exigências de mercado e dos produtores com a redução de custos de produção e o aumento da produtividade (MELETTI et al., 2005).

Levando em conta a grande variabilidade genética do maracujazeiro, alguns programas de melhoramento genético têm sido conduzidos visando à obtenção de variedades mais produtivas e resistentes a doenças (VIANA, 2014a).

A caracterização e a exploração da variabilidade genética entre e dentro das espécies de Passiflora podem revelar fontes de resistência ou tolerância de grande valor para o controle de doenças no campo ou utilização em programas de melhoramento genético (FALEIRO et al., 2005). No entanto, esses trabalhos ainda são incipientes e precisam ter continuidade visando o desenvolvimento de novas cultivares.

O maracujazeiro pode ser atacado por diversos fungos, vírus e bactérias, causando algumas doenças, das quais podemos destacar a bacteriose (Xanthomonas axonopodis pv. passiflorae) e a virose do endurecimento dos frutos (Cowpea aphid-borne mosaic virus - CABMV). Tais doenças podem causar morte precoce, diminuindo a vida útil da planta, gerando prejuízos de ordem social e financeira, pois o controle curativo das 
doenças é oneroso e muitas vezes não apresentam eficiência satisfatória (MIRANDA, 2004; LARANJEIRA, 2005).

Ao verificar a grande variabilidade genética de progênies existentes no programa de melhoramento genético de maracujazeiro azedo conduzido na Universidade de Brasília, as quais apresentam diferentes respostas aos patógenos causadores de doença, e ainda com a finalidade de desenvolver variedades mais resistente às doenças acima comentadas, o presente trabalho tem por objetivo a avaliação de progênies quanto a resistência a mancha oleosa e a virose do endurecimento do fruto em condições de casa de vegetação.

\section{MATERIAL E MÉTODOS}

\subsection{Local de desenvolvimento experimental}

O experimento foi instalado na Estação Experimental de Biologia (EEB) (latitude $16^{\circ} \mathrm{Sul}$ e longitude $48^{\circ}$ Oeste) da Universidade de Brasília (UnB), Distrito Federal, a altitude de 1010 m acima do nível do mar. O clima da região do tipo AW, caracterizado por chuvas concentradas no verão, de outubro a abril e invernos secos, de maio a setembro (MEDEIROS, 2005). O experimento foi conduzido em casa de vegetação, no período de maio a julho (14-26 $\left.{ }^{\circ} \mathrm{C} ; 62-80 \% \mathrm{UR}\right)$.

De acordo com os dados climáticos da estação número 83377, localizada na cidade satélite Sudoeste, Latitude $-15.78^{\circ}$, Longitude $-47.92^{\circ}$, Altitude 1159.54 metros, do INMET, foi elaborada uma figura (Figura 1) que representa alguns dados climáticos de março a julho de 2015. 


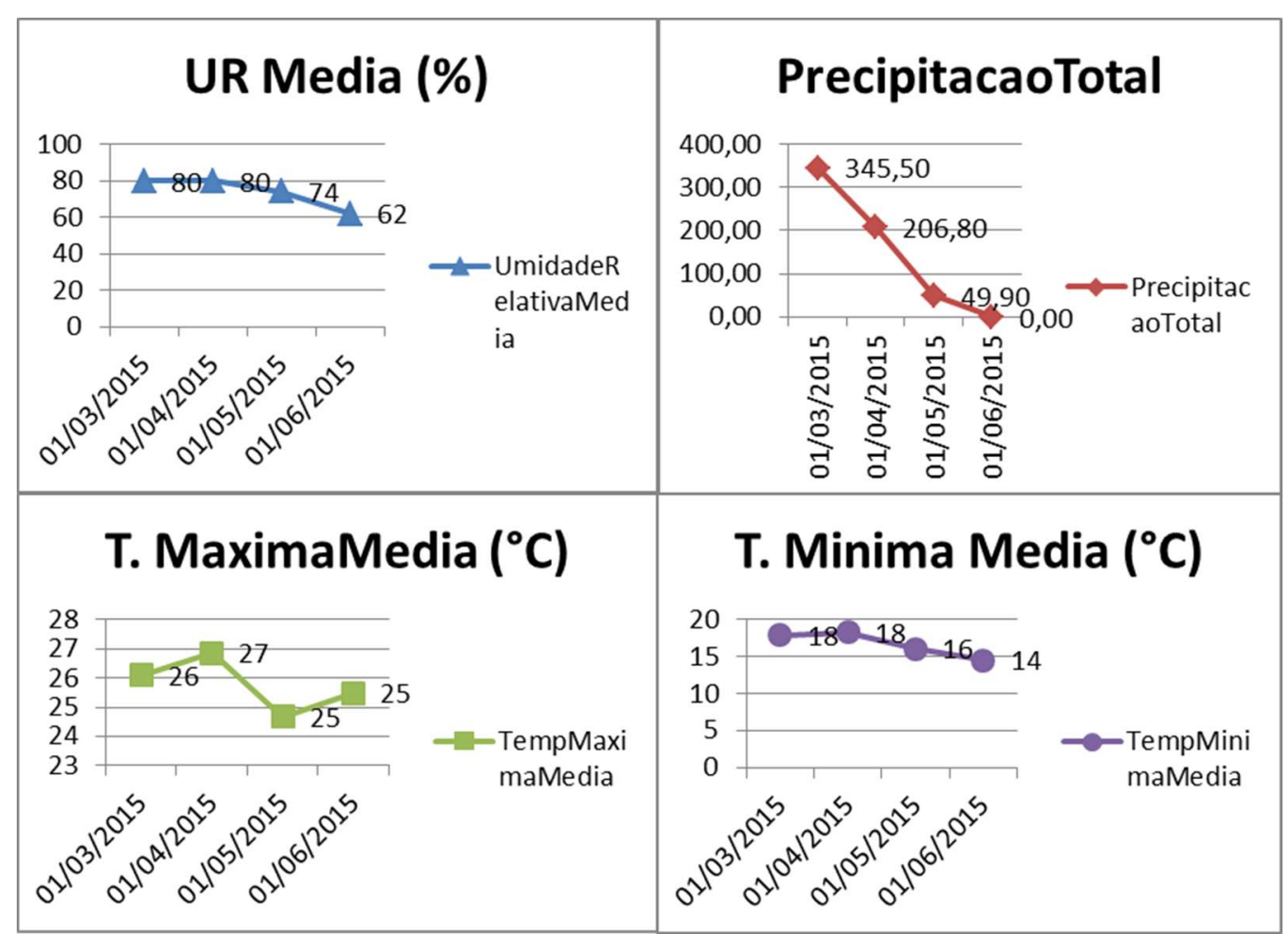

Figura 1. Dados climáticos da estação climatológica do Inmet, localizada na cidade satélite do Sudoeste, no período de 01 de março de 2015 à 30 de julho de 2015.

\subsubsection{Delineamento experimental}

O delineamento utilizado foi o de blocos casualizados, com 4 repetições e 5 plantas por parcela, testando-se 10 progênies, em 6 épocas de avaliação.

As parcelas avaliadas foram formadas por plantas provenientes de sementes de 10 progênies superiores, obtidos a partir de plantas selecionados, por alguns ciclos de seleção recorrente baseada em famílias de $1 / 2$ irmãos, de plantios anteriores feitos na Fazenda Água Limpa (FAL) da UnB (Tabela 1).

O material original utilizado foi proveniente de um programa de melhoramento desenvolvido pela Embrapa Cerrados juntamente com a Universidade de Brasília, levando em consideração a produtividade, a qualidade de fruto e a resistências as principais doenças. Posteriormente, tais materiais passaram por seleção recorrente baseada em família de $1 / 2$ irmãos. Os mesmos foram utilizados também para outras avaliações.

A produção de mudas de cada progênie foi feita a partir de sementes em bandejas de poliestireno estendido de 128 células, preenchidas com (40 ml/célula) a base de vermiculita e casca de Pinus sp. (Vivatto Slim Plus ${ }^{\circledR}$ ). Após 30 dias da germinação das 
sementes, as mudas foram transplantadas para sacos plásticos, com capacidade de 2 litros, contendo uma mistura de terra e adubo. As plantas foram mantidas em casa de vegetação, com irrigação diária e adubação de cobertura com uréia dissolvida em água $(0,1 \mathrm{~g} /$ planta a cada evento de adubação) a cada 2 semanas, até o início do experimento. Vinte plantas de cada acesso foram inoculadas aos 90 dias após a semeadura.

Tabela 1. Progênies originais de maracujazeiro azedo avaliados no Distrito Federal, e suas respectivas procedências.

\section{GENÓTIPOS}

\section{ORIGEM}

MAR 20\#21

MAR 20\#24

MAR 20\#41

ECL-7

GIGANTE AMARELO

MSCA

ROSA INTENSO

EC-RAM

RUBI GIGANTE
Inicialmente foi feita seleção massal de nove genótipos superiores, sendo eles: Maguary Mesa 1, Maguary Mesa 2, Havaiano, MSC (Marília Seleção Cerrado), Seleção DF, EC-2-0, F1 (Marília x Roxo Australiano), F1 (Roxo Fiji x Marília) e RC1 [ F1 (Marília $x$ Roxo Australiano) $x$ Marília (pai recorrente)] e posteriormente foram feitos alguns ciclos de seleção recorrente.

Inicialmente originário do cruzamento (Marilia X Rubi gigante) X Marilia, com posterior seleção recorrente.

Inicialmente derivado da cultivar Marília e posterior seleção recorrente.

Seleção recorrente de cultivar comercial

Pomar comercial de Marília Seleção Cerrado com posterior seleção recorrente.

Obtido por ciclos de seleção recorrente baseado em família de $1 / 2$ irmãos realizados em pomares do Distrito Federal.

Híbrido entre roxo australiano (P. edulis) x P. edulis f. flavicarpa com posterior seleção recorrente,

F1 (Roxo Australiano X Marília) com posterior seleção recorrente. 


\subsubsection{Bacteriose}

\section{Obtenção dos isolados}

$\mathrm{O}$ isolado de Xanthomonas axonopodis pv. passiflorae foi obtido a partir da coleção do Laboratório de Bacteriologia da Universidade de Brasília, preservado sob o número UnB 1393.

Para a multiplicação do patógeno, a solução bacteriana foi transferida para placas de Petri contendo meio de cultura 523, pelo método de estrias. Em seguida, as placas foram incubadas a $28-30^{\circ} \mathrm{C}$ por 72 horas (KADO \& HEWLETT, 1970). Colônias puras de cada isolado foram obtidas. Para a obtenção da suspensão bacteriana, as colônias puras foram transferidas para erlenmayers contendo $50 \mathrm{ml}$ de água destilada e a concentração ajustada, com o auxílio de um espectrofotômetro, a uma densidade óptica de 0,145 $\mathrm{A}_{550}$ ( $\left.10^{6} \mathrm{UFC} / \mathrm{mL}\right)$, pré-determinada por meio de curva de calibração (BOUZA, 2009).

\section{Inoculação}

Utilizou-se o método da agulha, sendo 4 agulhas fixadas em torno da parte terminal de uma caneta, formando um círculo. A cada perfuração, as agulhas foram imersas simultaneamente na suspensão bacteriana $\left(1 \times 10^{6} \mathrm{UFC} / \mathrm{mL}\right)$. Os orifícios foram feitos na segunda, terceira e quarta folha, a partir do ápice, sendo cada folha perfurada com o instrumento apenas uma vez, totalizando o total de 4 furos por folha. Após a inoculação, as plantas foram mantidas em câmara úmida por 72 horas.

\section{Avaliações}

Os sintomas foram avaliados 6 semanas consecutivas a partir do aparecimento dos primeiros sintomas. Foram realizadas 6 avaliações de severidade (\% de área foliar com lesões necróticas) e de incidência (\% de plantas com sintomas) da doença.

Para avaliação da severidade foi usada uma escala diagramática com notas de 0 a 5, proposta por DIAS (1990) e adaptada por BOUZA (2009), em que: 0 - ausência de sintoma; 1 - 1 a 10\% da área foliar com lesão necrótica; 2 - 11 a 25\% da área foliar com lesão necrótica; 3 - 26 a 50\% da área foliar com lesão necrótica; 4 - acima de 50\% da área foliar com lesão necrótica; 5 - desfolha. A área abaixo da curva de progresso da doença (AACPD) será calculada utilizando os dados recolhidas nas 6 avaliações da doenças, de acordo com CAMPBELL \& MADDEN (1990). AACPD foi utilizada como uma tentativa para diferenciar genótipos quanto à sua resistência à mancha oleosa. 
Baseando-se nas notas médias (NM) obtidas através da escala, as plantas foram classificadas em: resistentes $(\mathrm{R}), 0 \leq \mathrm{NM}<1$; moderadamente resistentes $(\mathrm{MR}), 1 \leq \mathrm{NM}$ $<2$; moderadamente suscetíveis (MS), $2 \leq \mathrm{NM}<3$; suscetíveis $(\mathrm{S}), 3 \leq \mathrm{NM}<4$; e altamente suscetíveis (AS), $\mathrm{NM} \geq 4$.

Os dados obtidos foram transformados por raiz de y e submetidos à análise de variância, utilizando-se o teste $\mathrm{F}$, ao nível de 5\% de probabilidade. As médias foram comparadas entre si pelo teste de Tukey ao nível de 5\%. Foram feitas análises de regressão e também de correlação linear entre as variáveis avaliadas, baseando-se na significância de seus coeficientes. As análises estatísticas foram feitas com o auxílio do software SANEST, de ZONTA \& MACHADO (1995). A classificação de intensidade da correlação para $0,05 \leq \mathrm{p} \geq 0,01$ foi considerada muito forte $(\mathrm{r} \pm 0,91 \mathrm{a} \pm 1,00)$, forte $(\mathrm{r} \pm$ $0,71 \mathrm{a} \pm 0,90)$, média $(\mathrm{r} \pm 0,51 \mathrm{a} \pm 0,70)$ e fraca $(\mathrm{r} \pm 0,31 \mathrm{a} \pm 0,50)$, de acordo com GONÇALVES \& GONÇALVES (1985), citado por GUERRA \& LIVERA (1999).

A herdabilidade no sentido amplo (ha), o coeficiente de variação genético $(\mathrm{CVg})$, e a relação entre o coeficiente de variação genético e ambiental $(\mathrm{CVg} / \mathrm{CVe})$, foram estimadas utilizando-se o aplicativo GENES (CRUZ, 2007).

\subsubsection{Virose}

\section{Obtenção dos isolados}

O isolado de CABMV foi coletado de folhas de maracujá azedo provenientes da Fazenda Água Limpa (UnB). As folhas mostravam sintomas severos de infecção por CABMV, incluindo mosaico, deformação foliar e bolhas. Foi confirmado que o isolado se tratava de CABMV pelo método de PCR (Reação em Cadeia da Polimerase) utilizando primers específicos contendo sequencias da capa proteica do vírus.

\section{Inoculação}

O inoculo foi preparado no almofariz por meio de maceração do material foliar infectado com o vírus CABMV na proporção $5 \mathrm{~g}$ de tecido (folha) para $10 \mathrm{ml}$ de tampão (fosfato de potássio $0,1 \mathrm{M}$ e sulfito de sódio $0,1 \mathrm{M}$ ), ajustado a $\mathrm{pH}=7$, e posteriormente adicionado uma pequena quantidade de abrasivo (Celite ${ }^{\circledR} 503$; Sigma-Aldrich Co.) ao extrato obtido (LEÃO et al., 2006, modificado por VIANA et al., 2014b). O patógeno foi 
inoculado mecanicamente (fricção das partes superiores das folhas com o dedo umedecido no extrato) em três folhas de cada planta. Aproximadamente 10 minutos após a inoculação, as plantas foram lavadas, evitando que o abrasivo queimasse as folhas inoculadas.

\section{Avaliações}

As avaliações foram realizadas com base na severidade (sintomas nas folhas), em intervalos de 7 dias, logo após o aparecimento dos primeiros sintomas da doença.

Para avaliação da severidade as plantas foram avaliadas de acordo com a escala diagramática com notas de 1 a 4, proposta por MAIA (2008), sendo 1 - para folhas sem sintomas; 2 - folhas apresentando mosaico leve e sem deformação foliares; 3 - folhas apresentando mosaico leve e com deformações na superfície foliar; 4 - folhas apresentando mosaico severo, deformações na superfície das folhas e do limbo foliar. A área abaixo da curva de progresso da doença (AACPD) será calculada utilizando os dados recolhidas nas 6 avaliações da doenças, de acordo com CAMPBELL \& MADDEN (1990). AACPD será utilizada como uma tentativa para diferenciar genótipos quanto à sua resistência a CABMV.

Baseando-se nas notas médias (NM) obtidas através da escala, as plantas foram classificadas em: resistentes $(\mathrm{R}), 1 \leq \mathrm{NM} \leq 1.5$; moderadamente suscetíveis (MS), 1.5 $<\mathrm{NM} \leq 2.5$; suscetíveis (S), $2.5<\mathrm{NM} \leq 3.5$; e altamente suscetíveis (AS), $3.5<\mathrm{NM} \leq 4$.

Os dados obtidos foram transformados por raiz y e submetidos à análise de variância, utilizando-se o teste $\mathrm{F}$, ao nível de $5 \%$ de probabilidade. As médias foram comparadas entre si pelo teste de Tukey ao nível de 5\%. Foram feitas análises de regressão e também de correlação linear entre as variáveis avaliadas, baseando-se na significância de seus coeficientes. As análises estatísticas foram feitas com o auxílio do software SANEST, de ZONTA \& MACHADO (1995). A classificação de intensidade da correlação para $0,05 \leq p \geq 0,01$ foi considerada muito forte $(r \pm 0,91 \mathrm{a} \pm 1,00)$, forte $(\mathrm{r} \pm$ $0,71 \mathrm{a} \pm 0,90)$, média $(\mathrm{r} \pm 0,51 \mathrm{a} \pm 0,70)$ e fraca $(\mathrm{r} \pm 0,31 \mathrm{a} \pm 0,50)$, de acordo com GONÇALVES \& GONÇALVES (1985), citado por GUERRA \& LIVERA (1999).

A herdabilidade no sentido amplo (ha), o coeficiente de variação genético (CVg), e a relação entre o coeficiente de variação genético e ambiental $(\mathrm{CVg} / \mathrm{CVe})$, foram estimadas utilizando-se o aplicativo GENES (CRUZ, 2007). 


\section{RESULTADOS E DISCUSSÃO}

\subsection{Bacteriose}

Houve diferença significativa da severidade (percentual da superfície da folha coberta com lesões) e incidência na folha (percentual de folhas com lesões) da bacteriose nas seis épocas de avaliação. A incidência variou 35,67\% entre as épocas 1 e 6 (Tabela 2). Em relação à severidade, houve variação de 4,27 entre a épocas que apresentou a menor e maior nota. Portanto, ocorreu um aumento gradativo em função da possível multiplicação do patógeno ao longo do tempo.

Tabela 2. Incidência na folha e severidade da bacteriose (Xanthomonas axonopodis pv. passiflorae) em 10 progênies de maracujazeiro azedo (Passiflora edulis Sims), sob diferentes épocas de avaliação em casa de vegetação. Brasília, UnB, 2015.

\begin{tabular}{|c|c|c|}
\hline Época & Incidência & Severidade \\
\hline 1 & $63,71 \mathrm{a}$ & $0,64 \mathrm{a}$ \\
\hline 2 & $92,13 \quad b$ & $1,31 \quad b$ \\
\hline 3 & $98,21 \quad b$ & 2,88 \\
\hline 4 & $99,00 \quad b$ & 4,45 \\
\hline 5 & $99,38 \quad b$ & 4,79 \\
\hline 6 & $99,38 \quad b$ & 4,91 \\
\hline
\end{tabular}

Médias seguidas por letras distintas na coluna diferem entre si pelo teste de Tukey ao nível de 5\% de significância.

A progênies Gigante Amarelo pl. 1, apresentou o menor valor para incidência em folha. Para severidade, as progênies Rosa Intenso, MAR 20\#24 pl. 2, Gigante Amarelo pl. 1, EC3-0, EC-RAM 3 e MSCA apresentaram os menores valores. Estas progênies diferiram significativamente das demais como pode ser observado na Tabela 3. O material Rubi Gigante apresentou o pior índice para as mesmas análises.

Avaliando a interação época dentro de progênie na incidência da bacteriose nas folhas, nas épocas 1, 3, 4, 5 e 6, não houve variação entre as progênies o que ocorreu na época 2. Na época 2, a progênie Rosa Intenso apresentou menor incidência em relação às demais progênies. $\mathrm{Na}$ interação progênie dentro das épocas, todos os materiais apresentaram diferenças entre as épocas com menores incidências nas primeiras épocas de avaliação (Tabela 4). 
Tabela 3. Média da incidência da bacteriose (Xanthomonas axonopodis pv. passiflorae) em folha e severidade em 10 progênies de maracujazeiro azedo (Passiflora edulis Sims), em seis épocas de avaliação em casa de vegetação. Brasília, UnB, 2015.

\begin{tabular}{lll}
\hline Tratamentos & Incidência & Severidade \\
\hline Gigante Amarelo pl. 1 & $85,74 \mathrm{a}$ & $3,07 \mathrm{a}$ \\
Rosa Intenso & $90,32 \mathrm{a} \mathrm{b}$ & $2,91 \mathrm{a}$ \\
MAR 20\#24 pl. 2 & $90,45 \mathrm{a} \mathrm{b}$ & $3,05 \mathrm{a}$ \\
\hline EC-RAM 3 & $91,06 \mathrm{a} \mathrm{b}$ & $3,09 \mathrm{a}$ \\
EC3-0 & $92,63 \mathrm{a} \mathrm{b}$ & $3,09 \mathrm{a}$ \\
ECL-7 & $92,74 \mathrm{a} \mathrm{b}$ & $3,21 \mathrm{a} \mathrm{b}$ \\
MSCA & $92,78 \mathrm{a} \mathrm{b}$ & $3,13 \mathrm{a}$ \\
MAR 20\#41 & $93,53 \mathrm{a} \mathrm{b}$ & $3,22 \mathrm{a} \mathrm{b}$ \\
MAR 20\#21 & $94,61 \mathrm{a}$ b & $3,22 \mathrm{a} \mathrm{b}$ \\
Rubi Gigante & $95,82 \mathrm{~b}$ & $3,51 \mathrm{~b}$ \\
\hline Médias seguidas por letras distintas diferem entre si pelo teste de Tukey ao nível de 5\% de significância.
\end{tabular}

Tabela 4. Interação entre época e progênie na avaliação de incidência na folha da bacteriose (Xanthomonas axonopodis pv. passiflorae) em 10 progênies de maracujazeiro azedo (Passiflora edulis Sims), em casa de vegetação. Brasília, UnB, 2015.

\begin{tabular}{lccrrrr}
\hline Progênie & Época 1 & Época 2 & Época 3 & Época 4 & Época 5 & Época 6 \\
\hline EC-RAM 3 & $53,00 \mathrm{aA}$ & $98,33 \mathrm{bB}$ & $100,00 \mathrm{bA}$ & $95,00 \mathrm{bA}$ & $100,00 \mathrm{bA}$ & $100,00 \mathrm{bA}$ \\
\hline EC3-0 & $55,75 \mathrm{aA}$ & $100,00 \mathrm{bB}$ & $100,00 \mathrm{bA}$ & $100,00 \mathrm{bA}$ & $100,00 \mathrm{bA}$ & $100,00 \mathrm{bA}$ \\
\hline ECL-7 & $64,75 \mathrm{aAB}$ & $91,66 \mathrm{bAB}$ & $100,00 \mathrm{bA}$ & $100,00 \mathrm{bA}$ & $100,00 \mathrm{bA}$ & $100,00 \mathrm{bA}$ \\
\hline Gigante Ama. pl. 1 & $51,50 \mathrm{aA}$ & $86,66 \mathrm{bAB}$ & $93,75 \mathrm{bA}$ & $95,00 \mathrm{bA}$ & $93,75 \mathrm{bA}$ & $93,75 \mathrm{bA}$ \\
\hline MAR 20\#21 & $71,00 \mathrm{aAB}$ & $96,66 \mathrm{bAB}$ & $100,00 \mathrm{bA}$ & $100,00 \mathrm{bA}$ & $100,00 \mathrm{bA}$ & $100,00 \mathrm{bA}$ \\
\hline MAR 20\#24 pl. 2 & $57,25 \mathrm{aAB}$ & $88,76 \mathrm{bAB}$ & $96,66 \mathrm{bA}$ & $100,00 \mathrm{bA}$ & $100,00 \mathrm{bA}$ & $100,00 \mathrm{bA}$ \\
\hline MAR 20\#41 & $69,5 \mathrm{aAB}$ & $95,00 \mathrm{bAB}$ & $96,66 \mathrm{bA}$ & $100,00 \mathrm{bA}$ & $100,00 \mathrm{bA}$ & $100,00 \mathrm{bA}$ \\
\hline MSCA & & & & & & \\
\hline
\end{tabular}

Médias seguidas pela mesma letra, letras minúsculas nas colunas e maiúsculas nas linhas, não diferem estaticamente, entre si pelo teste de Tukey ao nível de 5\% de significância.

Observando a interação época dentro de progênie na severidade à bacteriose, nas épocas 1, 2, 3 e 4 não houve variação, com exceção da maior severidade ocorrida na progênie Rubi Gigante nas épocas 2, 3 e 4. Nas demais épocas, as progênies foram divididas em dois ou três grupos com base na média da severidade. As progênies Gigante 
Amarelo pl. 1 e EC-RAM 3 apresentaram as menores médias de severidade. Na interação progênie dentro das épocas, todos os materiais todos os materiais apresentaram diferenças entre as épocas com menores médias de severidade nas primeiras épocas de avaliação (Tabela 5).

O cálculo da área abaixo da curva de progresso da doença foi efetuado para a análise de severidade da doença. Pela comparação de médias através do teste de Tukey, não houve diferença significativa entre as progênies ao nível de 5\%. (Tabela 6).

Tabela 5. Interação entre época e progênie na avaliação de severidade da bacteriose (Xanthomonas axonopodis pv. passiflorae) em 10 progênies de maracujazeiro azedo (Passiflora edulis Sims), em casa de vegetação. Brasília, UnB, 2015.

\begin{tabular}{|c|c|c|c|c|c|c|}
\hline Progênie & Época 1 & Época 2 & Época 3 & Época 4 & Época 5 & Época 6 \\
\hline EC-RAM 3 & $0,53 \mathrm{aA}$ & $1,29 \mathrm{aA}$ & $2,86 \mathrm{bA}$ & $4,69 \mathrm{cAB}$ & $4,94 \mathrm{cA}$ & $4,98 \mathrm{cA}$ \\
\hline EC3-0 & $0,56 \mathrm{aA}$ & $1,20 \mathrm{aA}$ & $2,72 \mathrm{bA}$ & $4,55 \mathrm{cAB}$ & $4,75 \mathrm{cA}$ & $4,81 \mathrm{cA}$ \\
\hline ECL-7 & $0,65 \mathrm{aA}$ & $1,38 \mathrm{aA}$ & $2,85 \mathrm{bA}$ & $4,58 \mathrm{cAB}$ & $4,87 \mathrm{cA}$ & $4,92 \mathrm{cA}$ \\
\hline Gigante Ama. pl. 1 & $0,51 \mathrm{aA}$ & $1,22 \mathrm{aA}$ & $2,58 \mathrm{bA}$ & $4,32 \mathrm{cAB}$ & $4,83 \mathrm{cA}$ & $5,00 \mathrm{cA}$ \\
\hline MAR 20\#21 & $0,71 \mathrm{aA}$ & $1,34 \mathrm{aA}$ & $3,05 \mathrm{bB}$ & $4,43 \mathrm{cAB}$ & $4,88 \mathrm{cA}$ & $4,88 \mathrm{cA}$ \\
\hline MAR 20\#24 pl. 2 & $0,57 \mathrm{aA}$ & $0,98 \mathrm{aA}$ & $2,46 \mathrm{bA}$ & $4,44 \mathrm{cAB}$ & $4,90 \mathrm{cA}$ & $4,95 \mathrm{cA}$ \\
\hline MAR 20\#41 & $0,69 \mathrm{aA}$ & $1,30 \mathrm{aA}$ & $3,00 \mathrm{bA}$ & $4,45 \mathrm{cAB}$ & $4,87 \mathrm{cA}$ & $4,98 \mathrm{cA}$ \\
\hline MSCA & $0,65 \mathrm{aA}$ & $1,43 \mathrm{aA}$ & $2,80 \mathrm{bA}$ & $4,37 \mathrm{cAB}$ & $4,60 \mathrm{cA}$ & $4,92 \mathrm{cA}$ \\
\hline Rosa Intenso & $0,73 \mathrm{aA}$ & $1,15 \mathrm{aA}$ & $2,58 \mathrm{bA}$ & $3,86 \mathrm{cA}$ & $4,38 \mathrm{cdA}$ & $4,75 \mathrm{dA}$ \\
\hline Rubi Gigante & $0,76 \mathrm{aA}$ & $1,76 \mathrm{bA}$ & $3,91 \mathrm{cB}$ & $4,76 \mathrm{~dB}$ & $4,92 \mathrm{dA}$ & $4,93 \mathrm{dA}$ \\
\hline
\end{tabular}

Médias seguidas pela mesma letra, letras minúsculas nas colunas e maiúsculas nas linhas, não diferem estaticamente, entre si pelo teste de Tukey ao nível de 5\% de significância.

Comparando os resultados obtidos neste trabalho com os apresentados por VIANA (2007), que avaliou a resistência de várias progênies à bacteriose em casa de vegetação, observa-se que há diferenças nas respostas dessas progênies à $X$. axonopodis pv. passiflorae com relação à análise de incidência. O material MSCA se comportou como resistente à doença e as progênies Gigante Amarelo, ECL-7 e EC3-0 como moderadamente resistentes. Nos resultados obtidos neste trabalho o material MSCA foi classificado como suscetível. Esta variação pode ter ocorrido em função da virulência dos inóculos utilizados. 
Tabela 6. Efeito da bacteriose (Xanthomonas axonopodis pv. passiflorae) em progênies de maracujazeiro azedo (Passiflora edulis Sims) a partir das médias da área abaixo da curva de progresso da doença (AACPD) obtida pelo índice de severidade de doença, em casa de vegetação. Brasília, UnB, 2015.

\begin{tabular}{ll}
\hline Tratamentos & Médias \\
\hline Rosa Intenso & 220,87 a \\
\hline MAR 20\#24 pl. 2 & $231,50 \mathrm{a}$ \\
\hline Gigante Amarelo pl. 1 & 236,37 a \\
\hline EC3-0 & $238,62 \mathrm{a}$ \\
\hline MSCA & $239,75 \mathrm{a}$ \\
MAR 20\#21 & $246,84 \mathrm{a}$ \\
MAR 20\#41 & $246,87 \mathrm{a}$ \\
\hline ECL-7 & $247,00 \mathrm{a}$ \\
EC-RAM 3 & $250,00 \mathrm{a}$ \\
\hline Rubi Gigante & $273,25 \mathrm{a}$ \\
\hline
\end{tabular}

Médias seguidas por letras distintas diferem entre si ao nível de significância de 5\%, comparadas pelo teste de Tukey.

BOUZA (2009), trabalhando com reação de genótipos à bacteriose em casa de vegetação, encontrou valores de incidência abaixo dos apresentados neste trabalho. A média das 5 épocas de avaliação da incidência em folhas feitas no ano de 2009 foi de $76,69 \%$ de incidência. Já no presente trabalho a média das 6 épocas de avaliação da incidência em folha obtida foi de $91,95 \%$.

Avaliando a reação de 12 progênies de maracujá azedo quanto a incidência e severidade da mancha oleosa causada por Xanthomonas axonopodis pv. passiflorae VIANA et al. (2014a), também encontrou diferença significativa em relação ao tempo, mostrando a importância de se realizar mais de uma avaliação.

FUHRMANN et al. (2014), avaliando o grau de resistência de 36 clones de maracujazeiro obtidos por seleção massal de sete progênies de híbridos interespecíficos a três isolados de Xanthomonas axonopodis pv. passiflorae, classificou a cultivar 'BRS Gigante Amarelo', utilizada como testemunha, a mais suscetível à bacteriose. No presente trabalho, uma planta selecionada a partir dessa cultivar apresentou menores níveis de incidência e severidade, evidenciando a possibilidade de seleção dentro da cultivar.

Os diferentes resultados mencionados podem ser explicados devido à variabilidade do material obtido por semente, o qual se encontra em processo de segregação. Outras disparidades também podem ser explicadas, bem como a variabilidade do patógeno, por meio de diferentes isolados de bactéria, grau de agressividade, diferentes concentrações de inóculo e o método de inoculação. A variação das condições climáticas, como temperatura e umidade relativa do ar, também podem influenciar no ritmo de crescimento do patógeno. Elementos, como diferentes condições nutricionais das mudas 
e fatores diversos, tais como idades das plantas inoculadas, número de plantas avaliadas e número de avaliações realizadas também podem provocar divergências (GONÇALVES, 2011).

A variação do índice de incidência (\%) e severidade (nota) da doença, em função do tempo de cada progênie, foi estimada através de regressão quadrática. Verificou-se que, a doença atingiu o seu ponto máximo antes do término das avaliações de severidade, exceto na progênie Rosa intenso (Tabela 7). Já se tratando da incidência, seu ponto máximo ocorreu entre os dias 23 e 25 após a inoculação para todos os genótipos.

VIANA (2014a), testando 18 genótipos, estimou valores de severidade e incidência, em função do tempo, através de regressão linear, verificando que a doença ainda estava em progresso na última avaliação.

Em condições de campo MARTINS et al. (2008), obteve equações de regressão para as análises de severidade e incidência do tipo quadrática com ponto de máximo de 54 e 56 dias, respectivamente.

Tabela 7. Ponto máximo de incidência e severidade da bacteriose (Xanthomonas axonopodis pv. passiflorae) em progênies de maracujazeiro azedo (Passiflora edulis Sims), dias após inoculação, estimada através de regressão quadrática. Brasília, UnB, 2015.

\begin{tabular}{lcccc}
\multicolumn{1}{c}{ Progênies } & Incidência & \multicolumn{3}{c}{ Severidade } \\
\hline Rubi Gigante & $\mathbf{R}^{\mathbf{2}}$ & Dias & $\mathbf{R}^{\mathbf{2}}$ & Dias \\
EC-RAM 3 & 0,83 & 23 & 0,97 & 31 \\
ECL-7 & 0,81 & 23 & 0,95 & 40 \\
MAR 20\#24 pl.2 & 0,92 & 24 & 0,95 & 42 \\
MAR 20\#41 & 0,93 & 25 & 0,94 & 52 \\
Gig Amarelo pl.1 & 0,88 & 25 & 0,96 & 43 \\
EC3-0 & 0,9 & 24 & 0,96 & 52 \\
MAR 20\#21 & 0,78 & 23 & 0,95 & 42 \\
MSCA & 0,85 & 24 & 0,96 & 41 \\
Rosa Intenso & 0,92 & 24 & 0,97 & 44 \\
\hline
\end{tabular}

As estimativas de parâmetros genéticos para as variáveis respostas analisadas estão apresentadas na Tabelas 8.

A herdabilidade observada para severidade foi de $30,61 \%$. A herdabilidade mede o grau de correspondência entre o valor fenotípico e valor genético, e valores altos deste parâmetro indicam que métodos de seleção simples, como seleção massal, podem levar a ganhos consideráveis, considerando que o ambiente apresenta pouca influência (FALCONER, 1987). 
O coeficiente de variação genético para severidade apresentou o valor de 2,78\% o que indica que o progresso genético com a seleção será baixo. Além disso, o coeficiente de variação ambiental observado também apresentou valores indicando que existe maior influência ambiental na característica. Dessa forma, verificando que o valor da razão $\mathrm{CVg} / \mathrm{CVe}$ foi menor que 1. Métodos simples de seleção, como seleção massal, possivelmente não proporcionaram bons resultados para o desenvolvimento de genótipos com resistência ao patógeno (ROCHA, 2014).

Os valores de herdabilidade e da relação $\mathrm{CVg} / \mathrm{CVe}$ podem ter ocorrido devido a diversos fatores, entre eles o tipo delineamento utilizado, condições da casa de vegetação, as diferentes concentrações do inoculo, entre outros.

Tabela 8. Resumo da análise de variância dos dados relativos à severidade da bacteriose (Xanthomonas axonopodis pv. passiflorae) em 10 progênies de maracujazeiro azedo (Passiflora edulis Sims), cultivados em casa de vegetação na Estação Experimental de Biologia. Brasília, UnB, 2015.

\begin{tabular}{l|l}
\hline Fonte de variação & Valores \\
\hline Cultivares (Quadrado Médio) & $22,01^{\text {ns }}$ \\
Resíduo (Quadrado Médio) & 27 \\
\hline $\mathrm{CV} \mathrm{( \% )}$ & 8,37 \\
Herdabilidade & 30,61 \\
\hline $\mathrm{CVg}$ & 2,78 \\
$\mathrm{CVe}$ & 8,42 \\
\hline $\mathrm{CVg} / \mathrm{CVe}$ & 0,33 \\
\hline Máximo & 3,58 \\
Mínimo & 2,25 \\
Média & 3,16 \\
\hline \multicolumn{2}{|c}{ ns Não significativo a 5\% de probabilidade pelo teste F. }
\end{tabular}

\subsection{Virose}

Houve diferença significativa na avaliação da severidade (percentual da superfície da folha coberta com lesões) à virose entre as seis épocas de avaliação. A época 1 
apresentou a menor média de notas $(1,12)$, enquanto as épocas 2, 3, 4 e 5 apresentaram as médias 2,10, 2,41, 2,56, 2,83 e 2,96, respectivamente (Tabela 9).

Tabela 9. Severidade da virose do endurecimento dos frutos (Cowpea aphid-borne virus) em 10 progênies de maracujazeiro azedo (Passiflora edulis Sims), em diferentes épocas de avaliação, em casa de vegetação. Brasília, UnB, 2015.

\begin{tabular}{cll}
\hline Época & \multicolumn{2}{l}{ Severidade } \\
\hline $\mathbf{1}$ & $1,13 \mathrm{a}$ & \\
$\mathbf{2}$ & $2,10 \mathrm{~b}$ & \\
$\mathbf{3}$ & $2,41 \quad \mathrm{c}$ \\
$\mathbf{4}$ & $2,57 \quad \mathrm{~d}$ \\
$\mathbf{5}$ & $2,84 \quad \mathrm{e}$ \\
$\mathbf{6}$ & $2,97 \quad \mathrm{e}$ \\
\hline
\end{tabular}

Médias seguidas por letras distintas diferem entre si pelo teste de Tukey ao nível de $5 \%$ de significância.

As progênies Rosa Intenso e MSCA, apresentaram os menores valores para severidade. Estas progênies diferiram significativamente das demais como pode ser observado na (Tabela 10). O material Rubi Gigante apresentou o pior índice para as mesmas análises.

Tabela 10. Média da severidade da virose do endurecimento dos frutos (Cowpea aphid-borne virus) em 10 progênies de maracujazeiro azedo (Passiflora edulis Sims), em seis épocas de avaliação, em casa de vegetação. Brasília, UnB, 2015.

\begin{tabular}{ll}
\hline Tratamentos & Severidade \\
\hline Rosa Intenso & $2.172917 \mathrm{a}$ \\
MSCA & $2.191667 \mathrm{a}$ \\
EC3-0 & $2.316667 \mathrm{a} \mathrm{b}$ \\
\hline MAR 20\#21 & $2.339583 \mathrm{a} \mathrm{b}$ \\
\hline MAR 20\#24 pl. 2 & $3.097917 \mathrm{a}$ \\
\hline ECL-7 & $2.341667 \mathrm{a} \mathrm{b}$ \\
EC-RAM 3 & $2.366667 \mathrm{ab}$ \\
Gigante Amarelo pl. 1 & $2.400000 \mathrm{ab}$ \\
\hline MAR 20\#41 & $2.400000 \mathrm{ab}$ \\
\hline Rubi Gigante & $2.475000 \quad \mathrm{~b}$ \\
\hline
\end{tabular}

Médias seguidas por letras distintas diferem entre si pelo teste de Tukey ao nível de $5 \%$ de significância.

Observando a interação época dentro de progênie na severidade à virose, houve variação apenas na época 2. As progênies variaram em até três grupos. Na interação progênie dentro das épocas, todos os materiais apresentaram variação, variando de dois a cinco grupos (Tabela 11). 
O cálculo da área abaixo da curva de progresso da doença foi efetuado para a análise de severidade da doença. Pela comparação de médias através do teste de Tukey, não houve diferença significativa entre as progênies ao nível de 5\% (Tabela 12).

Comparando-se os resultados obtidos neste trabalho com os apresentados por VIANA (2007), que avaliou a resistência de 18 progênies à CABMV em casa de vegetação, observa-se que há diferenças nas respostas dessas progênies com relação à análise de severidade. Dos 18 materiais avaliados apenas 3 coincidiram com os avaliados no presente trabalho, EC3-0, ECL-7 e MSCA, sendo os dois primeiros considerados medianamente resistentes (MR) e o último resistente (R) por VIANA (2007). Já no presente trabalho, embora a progênie MSCA tenha apresentado uma das menores notas de severidade, foi classificada como moderadamente suscetível (MS) assim como EC3-0 e ECL-7.

Tabela 11. Interação entre época e progênie na avaliação de severidade da virose do endurecimento dos frutos (Cowpea aphid-borne virus), em 10 progênies de maracujazeiro azedo (Passiflora edulis Sims), em casa de vegetação. Brasília, UnB, 2015.

\begin{tabular}{lcccccc}
\hline Progênie & Época 1 & Época 2 & Época 3 & Época 4 & Época 5 & Época 6 \\
\hline EC-RAM 3 & $1,25 \mathrm{aA}$ & $2,05 \mathrm{abB}$ & $2,30 \mathrm{aBC}$ & $2,70 \mathrm{aCD}$ & $2,90 \mathrm{aD}$ & $3,00 \mathrm{aD}$ \\
EC3-0 & $1,00 \mathrm{aA}$ & $1,90 \mathrm{aB}$ & $2,40 \mathrm{aBC}$ & $2,60 \mathrm{aCD}$ & $2,90 \mathrm{aCD}$ & $3,10 \mathrm{aD}$ \\
ECL-7 & $1,15 \mathrm{aA}$ & $1,90 \mathrm{aB}$ & $2,40 \mathrm{aBC}$ & $2,55 \mathrm{aC}$ & $2,90 \mathrm{aCD}$ & $3,15 \mathrm{aD}$ \\
Gigante Ama. pl. 1 & $1,05 \mathrm{aA}$ & $2,25 \mathrm{abB}$ & $2,50 \mathrm{aBC}$ & $\mathrm{aBCD}$ & $2,95 \mathrm{aCD}$ & $3,10 \mathrm{aD}$ \\
\hline MAR 20\#21 & $1,10 \mathrm{aA}$ & $2,30 \mathrm{abB}$ & $2,45 \mathrm{aB}$ & $2,62 \mathrm{aB}$ & $2,77 \mathrm{aB}$ & $2,79 \mathrm{aB}$ \\
MAR 20\#24 pl. 2 & $1,15 \mathrm{aA}$ & $2,00 \mathrm{abB}$ & $2,40 \mathrm{aBC}$ & $2,75 \mathrm{aC}$ & $2,90 \mathrm{aC}$ & $2,95 \mathrm{aC}$ \\
MAR 20\#41 & $1,15 \mathrm{aA}$ & $2,30 \mathrm{abB}$ & $2,50 \mathrm{aBC}$ & $2,55 \mathrm{aBC}$ & $2,85 \mathrm{aBC}$ & $2,90 \mathrm{aC}$ \\
MSCA & & & & & & \\
& $1,10 \mathrm{aA}$ & $1,90 \mathrm{aB}$ & $2,25 \mathrm{aBC}$ & $2,40 \mathrm{aBC}$ & $2,75 \mathrm{aC}$ & $2,75 \mathrm{aC}$ \\
\hline Rosa Intenso & $1,10 \mathrm{aA}$ & $1,85 \mathrm{aB}$ & $2,30 \mathrm{aBC}$ & $\mathrm{aBCD}$ & $2,60 \mathrm{aCD}$ & $2,86 \mathrm{aD}$ \\
\hline Rubi Gigante & $1,20 \mathrm{aA}$ & $2,55 \mathrm{bB}$ & $2,60 \mathrm{aB}$ & $2,60 \mathrm{aB}$ & $2,85 \mathrm{aB}$ & $3,05 \mathrm{aB}$ \\
\hline
\end{tabular}

Médias seguidas pela mesma letra, letras minúsculas nas colunas e maiúsculas nas linhas, não diferem estaticamente, entre si pelo teste de Tukey ao nível de 5\% de significância. 
Tabela 12. Efeito da virose do endurecimento dos frutos (Cowpea aphid-borne virus) em progênies de maracujazeiro azedo (Passiflora edulis Sims) a partir das médias da área abaixo da curva de progresso da doença (AACPD) obtida pelo índice de severidade de doença em casa de vegetação. Brasília, UnB, 2015.

\begin{tabular}{ll}
\hline Tratamentos & Médias \\
\hline Rosa Intenso & $165,84 \mathrm{a}$ \\
MSCA & $168,37 \mathrm{a}$ \\
EC3-0 & $177,75 \mathrm{a}$ \\
ECL-7 & $178,50 \mathrm{a}$ \\
\hline EC-RAM 3 & $181,12 \mathrm{a}$ \\
MAR 20\#21 & $181,40 \mathrm{a}$ \\
MAR 20\#24 pl. 2 & $181,50 \mathrm{a}$ \\
\hline MAR 20\#41 & $183,37 \mathrm{a}$ \\
Gigante Amarelo pl. 1 & $184,87 \mathrm{a}$ \\
Rubi Gigante & $190,87 \mathrm{a}$ \\
\hline
\end{tabular}

Médias seguidas por letras distintas diferem entre si ao nível de significância de 5\%, comparadas pelo teste de Tukey.

As progênies EC3-0 e ECL-7 também foram avaliados em campo por ABREU (2006) e SOUSA (2005), sendo que no primeiro trabalho, ambas progênies foram consideradas medianamente suscetíveis (MS), e para no segundo trabalho, a EC3-0 como resistente (R) e a ECL-7 como medianamente suscetível (MS).

Testando 36 genótipos em casa de vegetação, VIANA et al. (2014b) também constataram diferenças estatísticas entre os genótipos avaliados, com relação à de severidade. Todos foram considerados medianamente resistentes (MR) ao vírus Cowpea aphid-borne mosaic virus (CABMV). Já no presente trabalho, dos 10 materiais analisados, 9 foram classificados como moderadamente suscetível (MS) e 1, progênie MAR 20\#24 pl. 2, como suscetível (S) à virose em casa de vegetação, diferentemente do trabalho de VIANA, et al. (2014b), onde o genótipo MAR 20\#24 foi selecionado para dar continuidade ao programa de melhoramento.

Assim como nas inoculações com Xanthomonas axonopodis pv. passiflorae, diferentes resultados mencionados podem ser explicados devido à variabilidade do material obtido por semente, o qual se encontra em processo de segregação e seleção recorrente. Outras disparidades também podem ser explicadas, bem como a variabilidade do patógeno, por meio de diferentes isolados, grau de agressividade, diferentes concentrações de inóculo e o método de inoculação. A variação das condições climáticas, como temperatura e umidade relativa do ar, também podem influenciar no ritmo de crescimento do patógeno. Elementos, como diferentes condições nutricionais das mudas e fatores diversos, assim como idades das plantas inoculadas, número de plantas avaliadas e número de avaliações realizadas também podem provocar divergências. 
A variação do índice de severidade (nota) e incidência (\%) da doença, em função do tempo, de cada progênie foi estimada através de regressão linear (Tabela 13). Conforme os dados apresentados, a doença atingiu o seu ponto máximo antes do término das avaliações de severidade em 9 das 10 progênies avaliadas.

Tabela 13. Ponto máximo de incidência e severidade da virose do endurecimento dos frutos (Cowpea aphid-borne virus), em maracujazeiro azedo (Passiflora edulis Sims), dias após inoculação, estimada através de regressão quadrática. Brasília, UnB, 2015.

\begin{tabular}{lcccc}
\multicolumn{1}{c}{ Progênies } & \multicolumn{2}{c}{ Incidência } & \multicolumn{2}{c}{ Severidade } \\
\hline Rubi Gigante & $\mathbf{R}^{\mathbf{2}}$ & Dias & $\mathbf{R}^{\mathbf{2}}$ & Dias \\
EC-RAM 3 & 0,78 & 23 & 0,83 & 29 \\
ECL-7 & 0,96 & 27 & 0,98 & 35 \\
\hline MAR 20\#24 pl.2 & 0,95 & 25 & 0,98 & 41 \\
MAR 20\#41 & 0,93 & 25 & 0,99 & 31 \\
Gig Amarelo pl.1 & 0,85 & 25 & 0,91 & 29 \\
EC3-0 & 0,88 & 24 & 0,91 & 32 \\
MAR 20\#21 & 0,94 & 25 & 0,98 & 35 \\
MSCA & 0,85 & 25 & 0,91 & 27 \\
Rosa Intenso & 0,98 & 26 & 0,97 & 33 \\
\hline
\end{tabular}

VIANA (2014b), testando 36 genótipos em casa de vegetação, estipulou a variação dos valores no índice de severidade da doença e incidência (\%) em função do tempo por meio de regressão polinomial. As duas curvas, de severidade e de incidência, apresentam como ponto de máximo, aproximadamente, 30 e 24 dias após a inoculação, respectivamente, indicando os pontos em que a doença atingiu a maior intensidade. Já no presente trabalho, as curvas apresentaram ponto máximo de, aproximadamente, 27 e 37 dias após a inoculação para incidência e severidade respectivamente.

Em condições de campo, ABREU (2006) obteve para ambas as análises, severidade e incidência, pontos de mínimo de 40 e 52 dias após a primeira avaliação, respectivamente.

As estimativas de parâmetros genéticos para as variáveis respostas analisadas estão apresentadas na Tabelas 14.

A herdabilidade observada para incidência foi de $28,34 \%$. A razão $\mathrm{CVg} / \mathrm{CVe}$ foi de 0,31 , abaixo de 1 , o que reflete uma condição desfavorável a seleção, utilizando métodos simples, uma vez que a variância genética foi menor que a variância ambiental. 


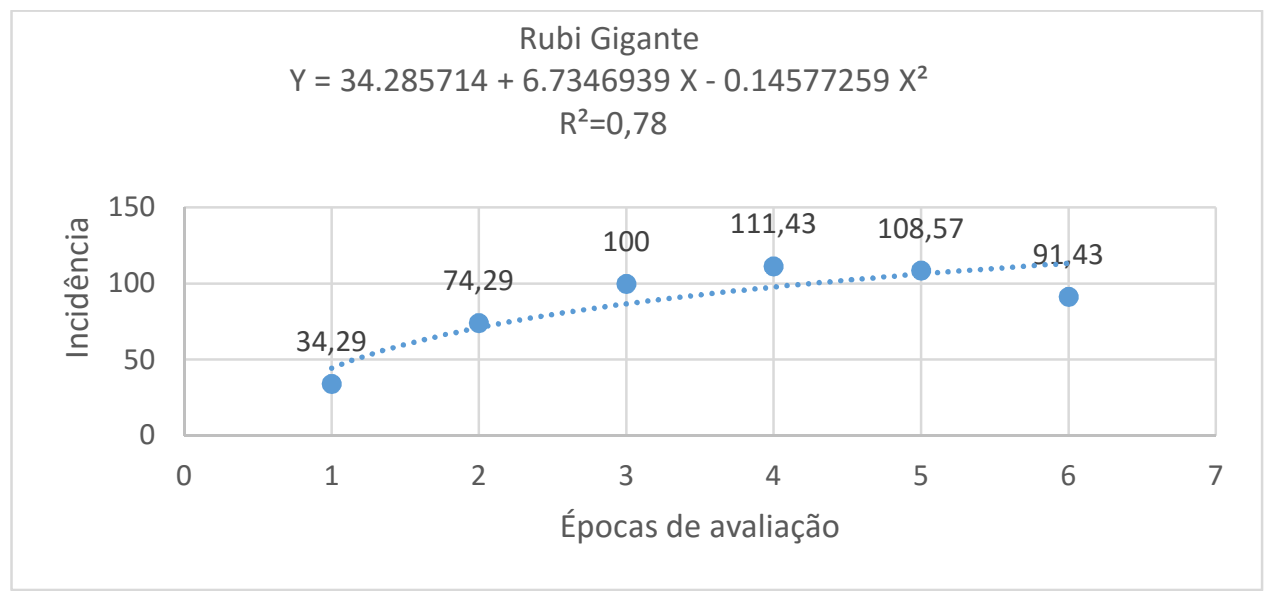

Figura 2.1. Incidência da virose do endurecimento dos frutos (Cowpea aphid-borne virus) na progênie Rubi Gigante de maracujazeiro azedo (Passiflora edulis Sims), em 6 avaliações semanais. As curvas referem-se aos valores estimados e os pontos aos valores observados. Brasília-UnB, 2015.

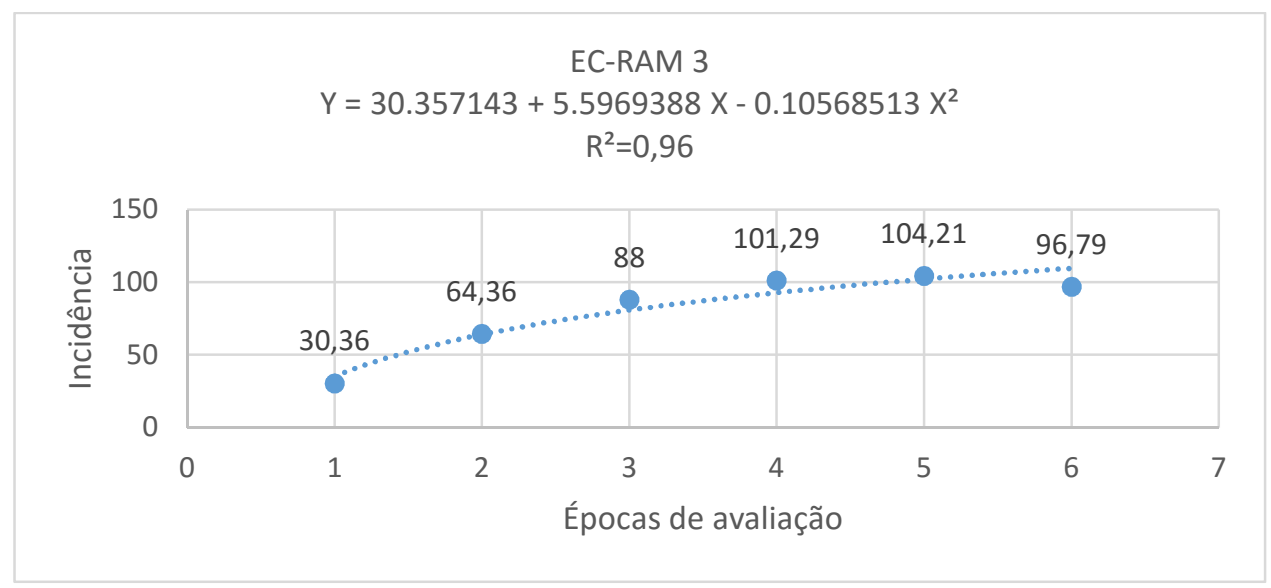

Figura 2.2. Incidência da virose do endurecimento dos frutos (Cowpea aphid-borne virus) na progênie ECRAM 3 de maracujazeiro azedo (Passiflora edulis Sims), em 6 avaliações semanais. As curvas referem-se aos valores estimados e os pontos aos valores observados. Brasília-UnB, 2015.

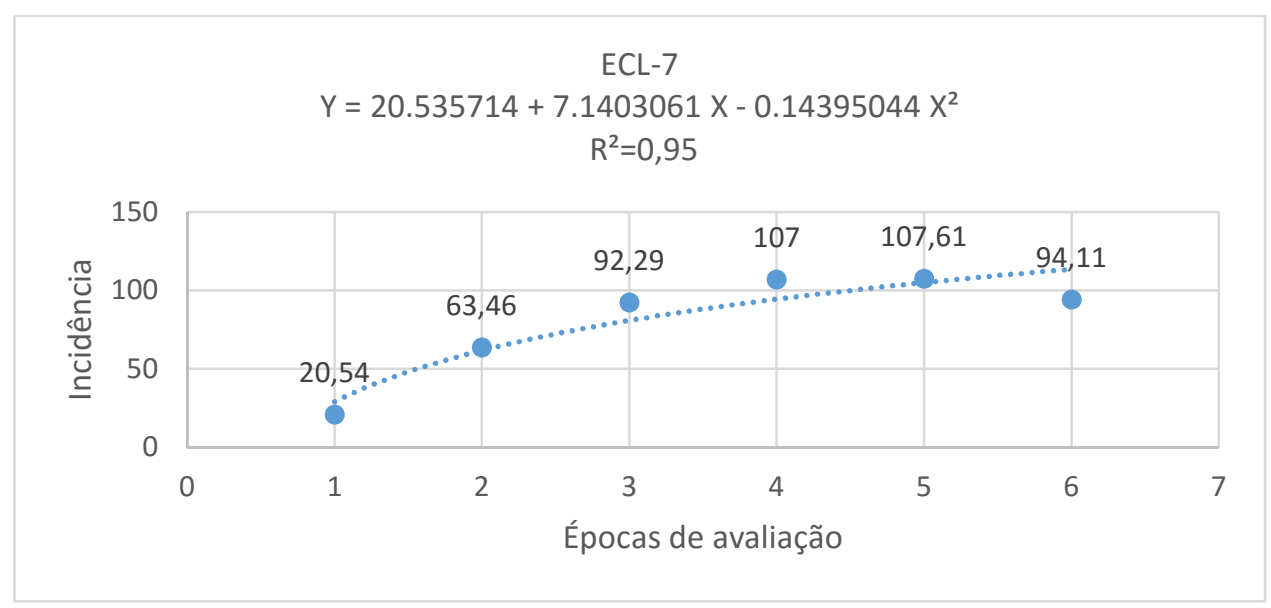

Figura 2.3. Incidência da virose do endurecimento dos frutos (Cowpea aphid-borne virus) na progênie ECL7 de maracujazeiro azedo (Passiflora edulis Sims), em 6 avaliações semanais. As curvas referem-se aos valores estimados e os pontos aos valores observados. Brasília-UnB, 2015. 


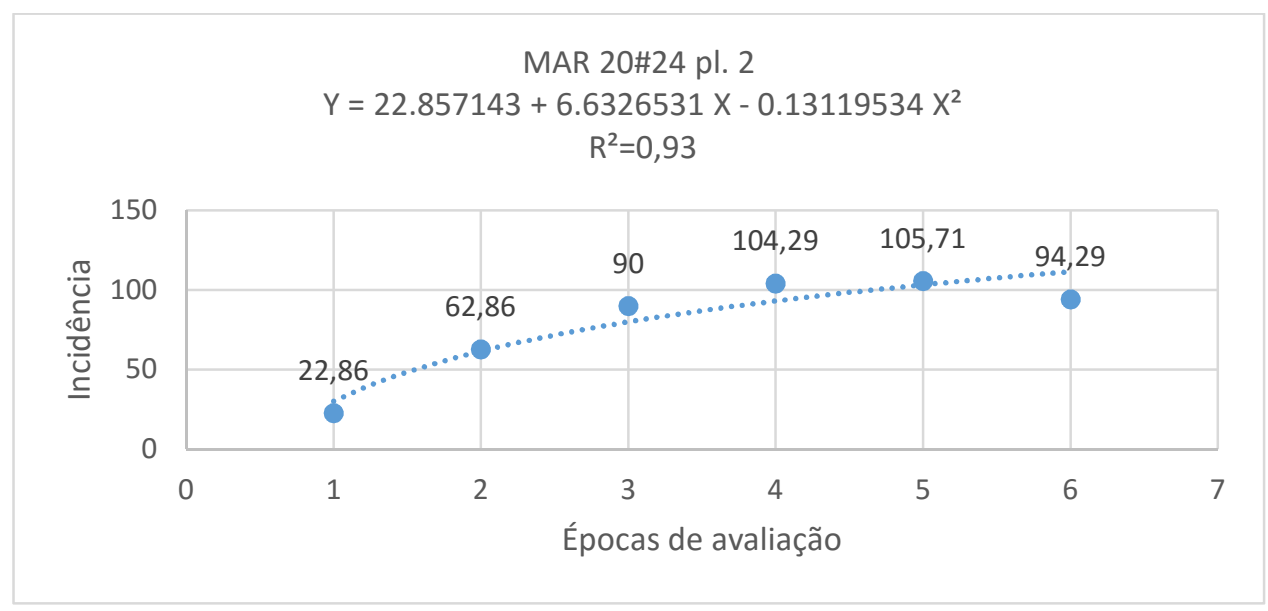

Figura 2.4. Incidência da virose do endurecimento dos frutos (Cowpea aphid-borne virus) na progênie MAR $20 \# 24$ pl. 2 de maracujazeiro azedo (Passiflora edulis Sims), em 6 avaliações semanais. As curvas referem-se aos valores estimados e os pontos aos valores observados. Brasília-UnB, 2015.

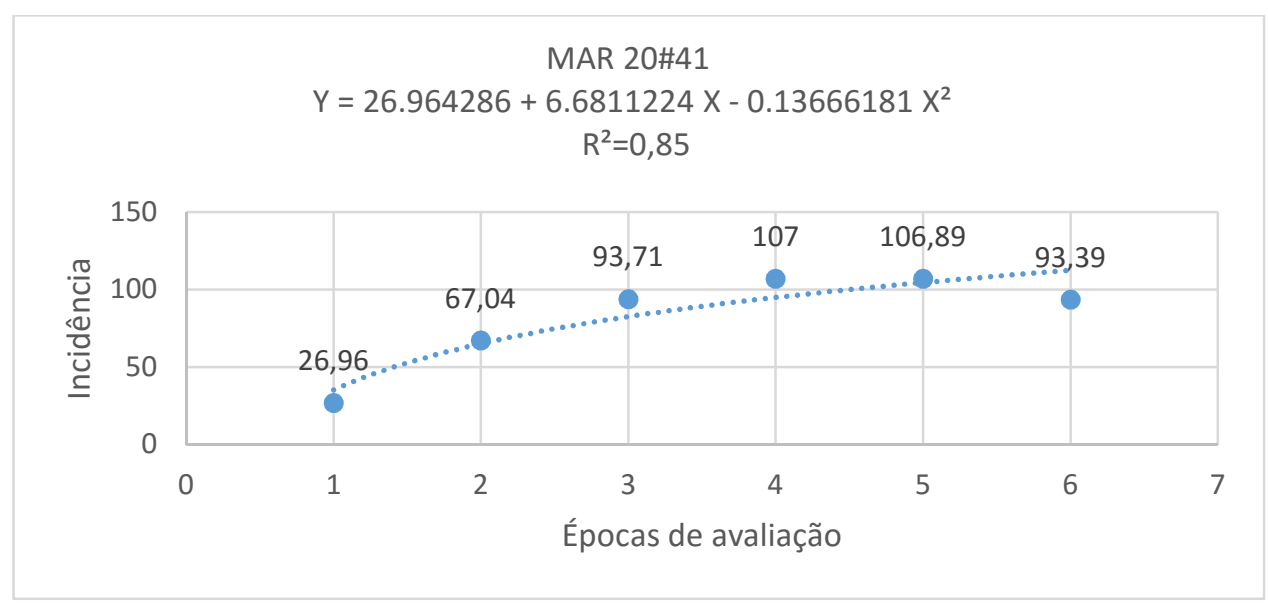

Figura 2.5. Incidência da virose do endurecimento dos frutos (Cowpea aphid-borne virus) na progênie MAR 20\#41 de maracujazeiro azedo (Passiflora edulis Sims), em 6 avaliações semanais. As curvas referem-se aos valores estimados e os pontos aos valores observados. Brasília-UnB, 2015.

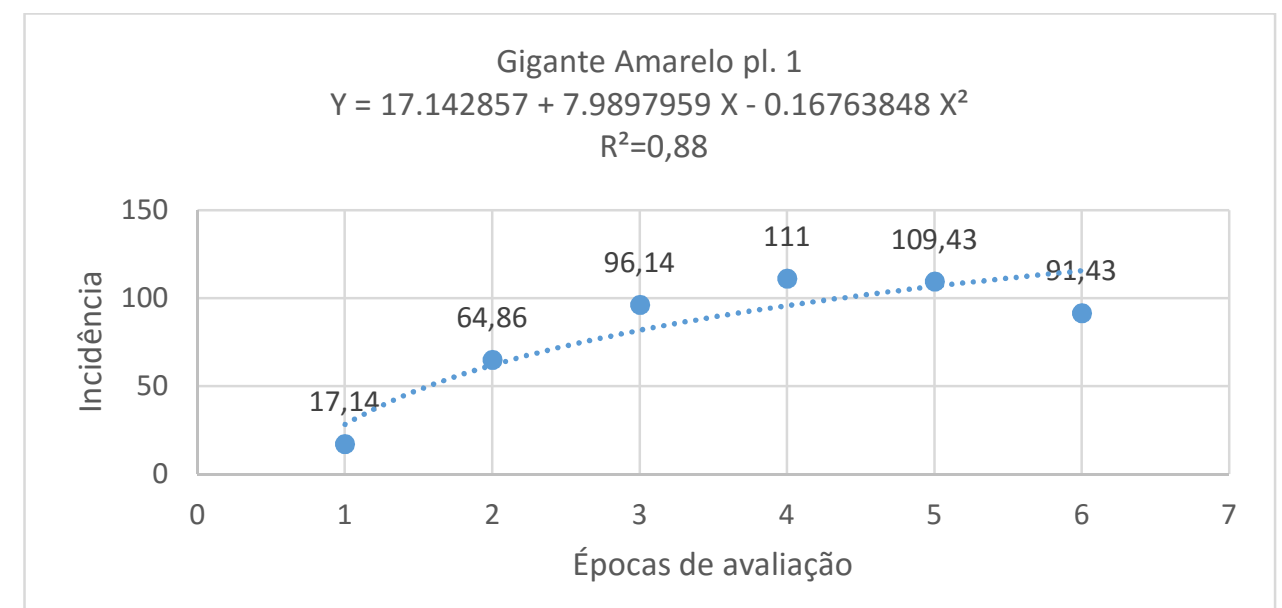

Figura 2.6. Incidência da virose do endurecimento dos frutos (Cowpea aphid-borne virus)na progênie Gigante Amarelo pl. 1 de maracujazeiro azedo (Passiflora edulis Sims), em 6 avaliações semanais. As curvas referem-se aos valores estimados e os pontos aos valores observados. Brasília-UnB, 2015. 


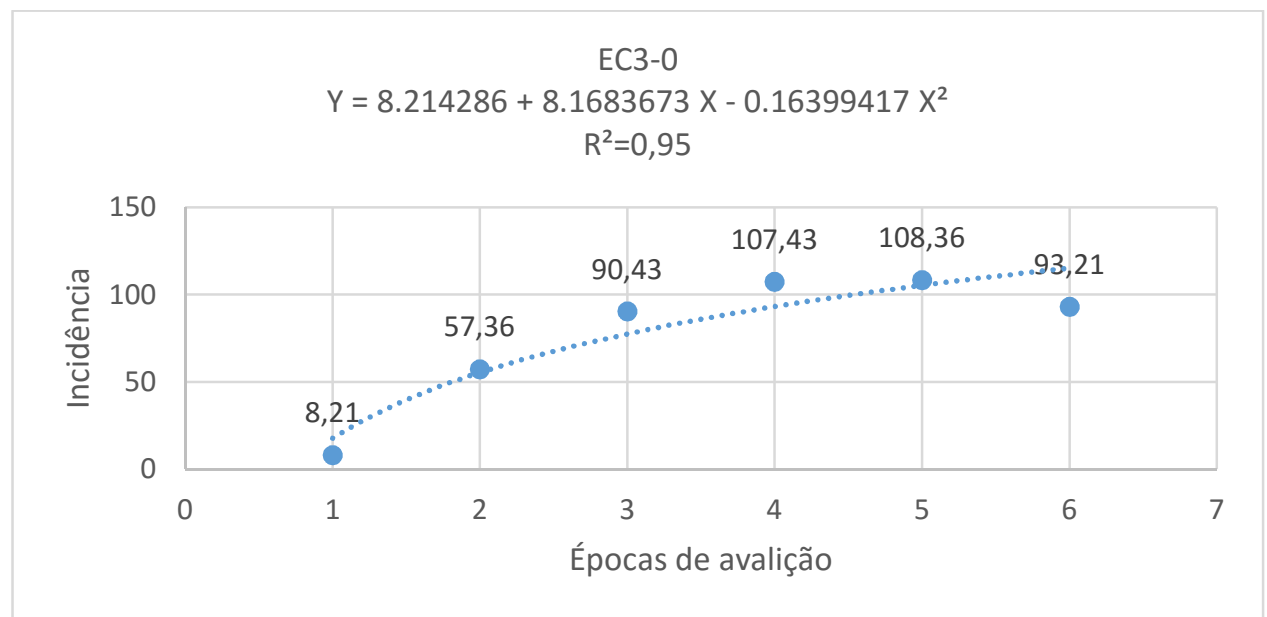

Figura 2.7. Incidência da virose do endurecimento dos frutos (Cowpea aphid-borne virus) em progênie EC3-0 de maracujazeiro azedo (Passiflora edulis Sims), em 6 avaliações semanais. As curvas referem-se aos valores estimados e os pontos aos valores observados. Brasília-UnB, 2015.

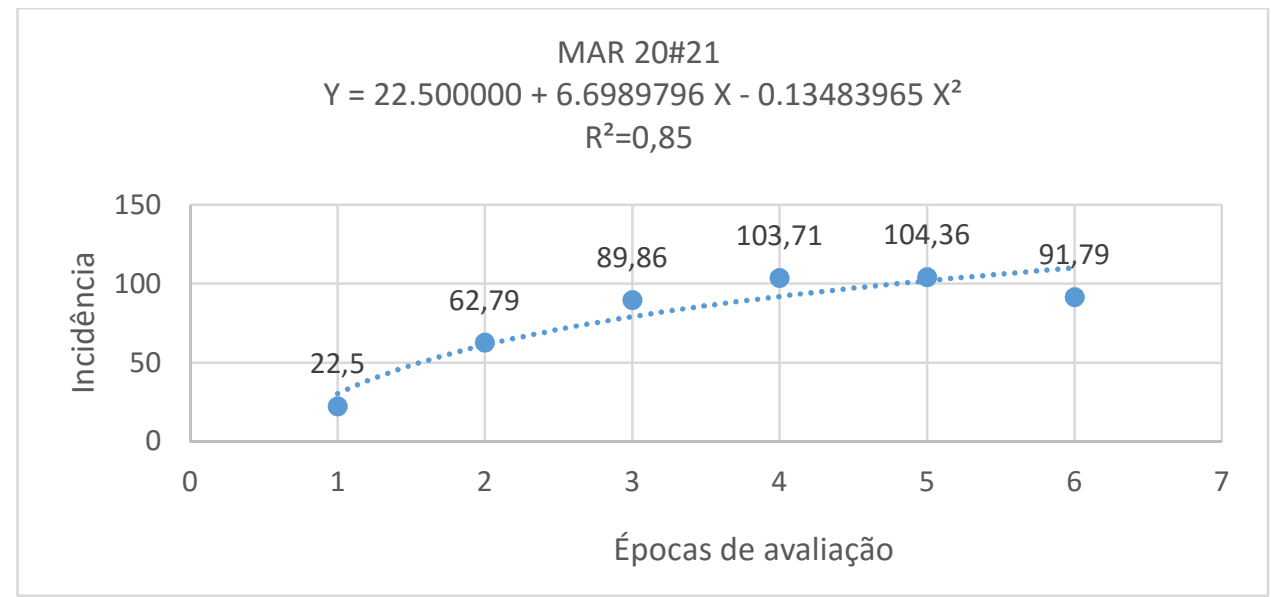

Figura 2.8. Incidência da virose do endurecimento dos frutos (Cowpea aphid-borne virus) na progênie MAR 20\#21 de maracujazeiro azedo (Passiflora edulis Sims), em 6 avaliações semanais. As curvas referem-se aos valores estimados e os pontos aos valores observados. Brasília-UnB, 2015.

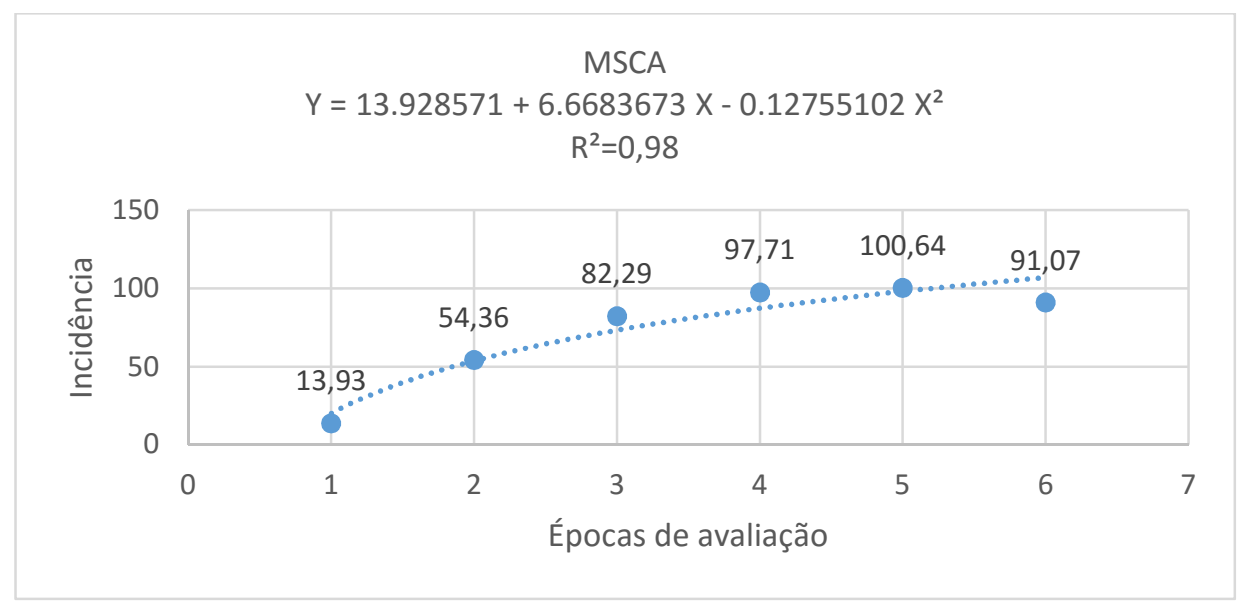

Figura 2.9. Incidência da virose do endurecimento dos frutos (Cowpea aphid-borne virus) na progênie (MSCA) de maracujazeiro azedo (Passiflora edulis Sims), em 6 avaliações semanais. As curvas referemse aos valores estimados e os pontos aos valores observados. Brasília-UnB, 2015. 


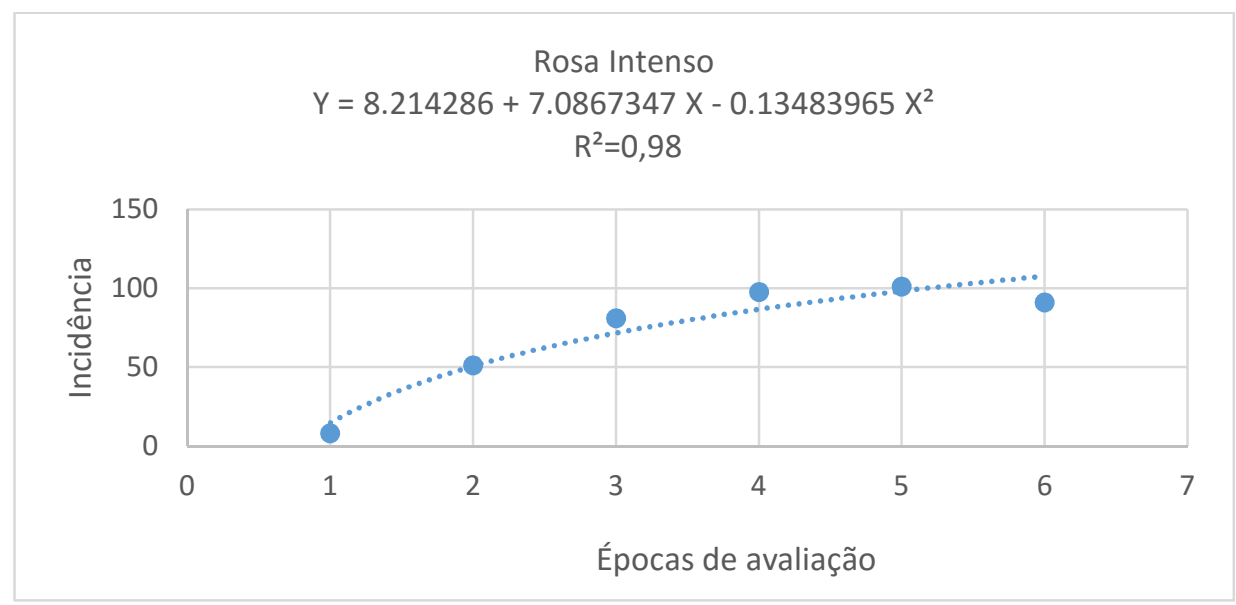

Figura 2.10. Incidência da virose do endurecimento dos frutos (Cowpea aphid-borne virus) na progênie (Rosa Intenso) de maracujazeiro azedo (Passiflora edulis Sims), em 6 avaliações semanais. As curvas referem-se aos valores estimados e os pontos aos valores observados. Brasília-UnB, 2015.

Tabela 14. Resumo da análise de variância dos dados relativos a incidência da virose do endurecimento dos frutos (Cowpea aphid-borne virus), em 10 progênies de maracujazeiros, cultivados em casa de vegetação na Estação Experimental de Biologia. Brasília, UnB, 2015.

\begin{tabular}{l|l}
\hline Fonte de variação & Valores \\
\hline Cultivares (Quadrado Médio) & $23,88^{\text {ns }}$ \\
Resíduo (Quadrado Médio) & 27 \\
\hline CV (\%) & 9,23 \\
Herdabilidade & 28,34 \\
\hline CVg & 2,93 \\
CVe & 9,45 \\
\hline CVg/CVe & 0,31 \\
\hline Máximo & 90,00 \\
Mínimo & 53,33 \\
Média & 79,41 \\
\hline \multicolumn{2}{c}{ ns Não significativo a 5\% de probabilidade pelo teste F. }
\end{tabular}

Segundo VENCOVSKY (1987), a relação entre CVg/CVe, denominada índice de variação (Iv), é um importante indicador das possibilidades de sucesso na obtenção de ganhos genéticos por meio de seleção. A situação é favorável quando os valores são maiores que 1,0 . 


\section{CONCLUSÕES}

As progênies Gigante Amarelo pl. 1, Rosa Intenso e MAR20\#24 pl. 2 apresentaram as menores severidades e incidências na folha ao contrário das progênies Rubi Gigante, MAR20\#21 e MAR20\#41. Nove das progênies foram consideradas suscetível (S), e apenas 1, progênie Rosa Intenso, como moderadamente suscetível (MS) à bacteriose em casa de vegetação.

As progênies com menor severidade foram Rosa Intenso, MSCA e EC3-0. Dos 10 materiais analisados, 9 foram classificados como moderadamente suscetível (MS) e 1, progênie MAR 20\#24 pl. 2, como suscetível (S) à virose em casa de vegetação.

Valores baixos de herdabilidade e razão $\mathrm{CVg} / \mathrm{CVe}$ foram observados para as variáveis analisadas. 


\section{REFERÊNCIAS BIBLIOGRÁFICAS}

ABREU, S. P. M. Desempenho agronômico, características físico-químicas e reação a doenças em genótipos de maracujá-azedo cultivados no Distrito Federal. 2006. 129p. Dissertação (Mestrado em Ciências Agrárias). Universidade de Brasília, Brasília, 2006.

ALVES, J. C. S. Estimativa de parâmetros genéticos para caracteres de semente e de planta em populações de cenoura (Daucus carota $\mathbf{L}$.) derivadas da cultivar Brasília. Brasília: UNB. 67p. (Dissertação de Mestrado), 2004.

BOUZA, R.B. Reação em progênies de maracujá-azedo à antracnose, septoriose, cladosporiose bacteriose em condições de campo e casa de vegetação. 2009. 160p. Dissertação (Mestrado em Fitopatologia). Universidade de Brasília, Brasília, 2009.

CAMPBELL, C.L.; MADDEN, L.V. Introducyion to plant disease epidemiology. New York: John Wiley \& Sons, 1990. 532p.

COSTA, A. F. S. da; COSTA, A. N. da. Polo de Maracujá no Estado do Espírito Santo: Importância socioeconômica e potencialidades. In: COSTA, A. F. S. da; COSTA, A. N. da. Tecnologias para produção de maracujá. Vitória-ES: INCAPER, p.13-20. 2005.

CRUZ, C. D. Programa Genes: aplicativo computacional em genética e estatística. Viçosa: Editora UFV, 442p, 1997.

DIAS, S.C. Morte precoce do maracujazeiro amarelo (Passiflora edulis f. flavicarpa) causada por patógenos que afetam a parte aérea da planta. 1990. 137f. Dissertação (Mestrado em Fitopatologia) - Universidade de Brasília, 1990.

FALCONER, D.S. Introdução à genética quantitativa. Viçosa: UFV, 279p, 1987.

FALEIRO, F.G.; JUNQUEIRA, N.T.V. Recursos genéticos: conservação, caracterização e uso. In: FALEIRO, F.G.; ANDRADE, S.R.M.; REIS JÚNIOR, F.B. Biotecnologia: estado da arte e aplicações na agropecuária. Planaltina,DF: Embrapa Cerrados, 2011a. p. 513-551.

FALEIRO, F. G.; JUNQUEIRA, N. T. V.; FÁVERO, A. P.; LOPES, M. A. Prémelhoramento de plantas: experiências de sucesso. In: FALEIRO, F. G.; NETO, A. L. F.; JÚNIOR, W. Q. R. Pré-melhoramento, melhoramento e pós melhoramento: estratégias e desafios. Planaltina, DF: Embrapa Cerrados; Brasília DF: Embrapa Informação Tecnológica, 2008.

FALEIRO, F.G.; JUNQUEIRA, N.T.V.; BRAGA, M.F. Germoplasma e melhoramento genético do germoplasma - desafio da pesquisa. In: FALEIRO, F.G.; JUNQUEIRA, N.T.V.; BRAGA, M.F. (Ed.) Maracujá germoplasma e melhoramento genético. Brasília, DF: Embrapa Cerrados, 2005. p. 187-210. 
FERRAZ, J. V.; LOT, L. Fruta para consumo in natura tem boas perspectivas de renda. In: AGRIANUAL 2007: anuário estatístico da agricultura brasileira. São Paulo: FNP, 2007. p.387-394.

FUHRMANN, E.; JUNQUEIRA, N.T.V.; BLUM, L.E.B.; BRAGA, M.W.; BELLON, G.; JUNQUEIRA, K.P. Reação de híbridos interespecífi cos de Passiflora spp. à Xanthomonas axonopodis pv. passiflorae. Ciência Rural, v.44, n.8, ago, 2014.

GONÇALVES, I. M. P. Produtividade e reação de genótipos de maracujazeiro azedo a doenças em campo e casa de vegetação. Dissertação (Mestrado em Ciências Agrárias). Faculdade de Agronomia e Medicina Veterinária, Universidade de Brasília. Brasília, 2011. $121 \mathrm{p}$

GRECO, S.M.L. Caracterização físico-química e molecular de genótipos de maracujá azedo cultivados no Distrito Federal. Faculdade de Agronomia e Medicina Veterinária, Universidade de Brasília-Brasília, 2014; 149p. Tese de Doutorado.

GUERRA, N. B.; LIVERA, A. V. S. Correlação entre o perfil sensorial e determinações físicas e químicas do abacaxi cv. pérola. Revista Brasileira de Fruticultura, Cruz das Almas, v. 21, n.1, p.32-35, 1999.

KADO, C. L. \& HESKETT, M. S. Selective media for isolation of Agrobacterium, Corynebacterium, Erwinia, Pseudomonas and Xanthomonas. Phytopathology 60: 969976. 1970.

LARANJEIRA, F.F. Problemas e perspectivas da avaliação de doenças como suporte ao melhoramento do maracujazeiro. In: FALEIRO, F.G., JUNQUEIRA, N.T.V., BRAGA, M.F. (Ed.) Maracujá germoplasma e melhoramento genético. Brasília-DF: Embrapa Cerrados, 2005.p.161-183.

LEÃO, R. M. K. et al. Reação de progênies de maracujazeiro-azedo ao vírus do endurecimento do fruto (Cowpea aphid-borne mosaic virus - CABMV) em casa de vegetação. Bioscience journal, Uberlândia, v. 22, n. 2, p. 87-92, maio/ago. 2006.

MAIA, T. E. G. Desempenho agronômico e reação à verrugose e à virose do endurecimento dos frutos de progênies de maracujazeiro-azedo cultivados no Distrito Federal. Dissertação (Mestrado em Ciências Agrárias) Faculdade de Agronomia e Medicina Veterinária, Universidade de Brasília, 121p, 2008.

MARTINS, I.; PEIXOTO, J. R.; JUNQUEIRA, N. V. T.; MELLO, Sueli C M de. Reação de genótipos de maracujazeiro-amarelo ao Colletotrichum gloeosporioides. Revista Brasileira de Fruticultura, Jaboticabal - SP, v. 30, p. 639-643, setembro, 2008.

MELETTI, L.M.M.; SOARES-SCOTT, M.D.; BERNACCI, L.C.; PASSOS, I.R.S. Melhoramento genético do maracujá: passado e futuro. In: Faleiro, F.G.; Junqueira, N.T.V.; Braga, M.F. (Eds.) Maracujá: germoplasma e melhoramento genético. Planaltina,DF: Embrapa Cerrados, 2005. p. 55-78. 
MIRANDA, H.A. Incidência e severidade de Xanthomonas axonopodis pv. passiflorae, Colletotrichum gloeosporioides, Septoria passiflorae, Cladosporium herbarum e passion fruit woodiness virus em genótipos de maracujazeiro azedo cultivados no Distrito Federal. Brasília, 2004. 87f. Dissertação (Mestrado em Ciências Agrárias) - Faculdade de Agronomia e Medicina Veterinária, Universidade de Brasília, 2004.

REVISTA CAMPO E NEGÓCIO. Avanços do cultivo do maracujá no Brasil. Disponível em: <http://www.revistacampoenegocios.com.br/avancos-no-cultivo-demaracuja-no-brasil/> Acesso: Novembro de 2015.

ROCHA, M. R. D. Estratégias de seleção no melhoramento genético do maracujazeiro azedo. Rio Parnaíba, MG. Dissertação (Mestrado em agronomia) Universidade Federal de Viçosa. 2014.

VENCOVSKY, R. Herança quantitativa. In: PATERNIANI, E.; VIEGAS, G. P. (coord.). Melhoramento e produção de milho no Brasil. 2ed. Campinas: Fundação Cargil, p. 137-214, 1987.

VIANA, C.A. dos S. Resistência de genótipos de maracujá-azedo à bacteriose (Xanthomonas axonopodis pv. passiflorae) e à virose do endurecimento do fruto (Cowpea aphid-borne mosaic virus). 2007. 210 f. Dissertação (Mestrado em Fitopatologia). Universidade de Brasília, Brasília, 2007.

VIANA, C. A. S.; PIRES, M. C.; PEIXOTO, J. R.; JUNQUEIRA, N. T. V.; BLUM, L. E. B. Resistência parcial de genótipos de maracujá-azedo à virose do endurecimento do fruto (Cowpea aphid-borne mosaic virus - CABMV). Biosci. J., Uberlandia, v. 30, supplement 1, p. 338-345, June 2014b.

VIANA, C. A. S.; PIRES, M. C.; PEIXOTO, J. R.; JUNQUEIRA, N. T. V.; BLUM, L. E. B. Genótipos de maracujazeiro-azedo com resistência à bacteriose. Biosci. J., Uberlandia, v. 30, supplement 2, p. 591-598, Oct. 2014.

ZONTA, E.P.; MACHADO, A.A. Sistema de análises estatísticas (SANEST) para microcomputadores. In: Simpósio de estatística aplicada à experimentação, Piracicaba, 1995. Resumos... Campinas: Fundação Cargill, 1995. p.17-18. 


\section{CAPÍTULO 2}

AVALIAÇÃO AGRONÔMICA E REAÇÃO A BACTERIOSE E VIROSE DE 10 PROGÊNIES DE MARACUJÁ AZEDO EM CONDIÇÕES DE CAMPO 


\section{AVALIAÇÃO AGRONÔMICA E REAÇÃO A BACTERIOSE E VIROSE DE 10 PROGÊNIES DE MARACUJÁ AZEDO EM CONDIÇÕES DE CAMPO}

\section{RESUMO}

A carência de variedades altamente produtivas e resistentes à doenças é um fator limitante à melhoria da qualidade do fruto e ao aumento da produtividade da cultura do maracujazeiro. Esse trabalho teve como objetivo avaliar o desempenho agronômico e a resistência à bacteriose (Xanthomonas axonopodis pv. passiflorae) e à virose do endurecimento dos frutos (Cowpea aphid-borne mosaic virus - CABMV) do maracujazeiro azedo no Distrito Federal, em condições de campo. Foram utilizadas 10 progênies, em delineamento de blocos casualizados, com 7 plantas por parcela e 3 repetições. Foram realizadas 40 colheitas para avaliação agronômica, analisando as seguintes variáveis: produtividade estimada $(\mathrm{kg} / \mathrm{ha})$, número total de frutos por hectare, massa média de frutos (g) e classificação dos frutos quanto ao diâmetro equatorial em cinco categorias. As análises das características físicas consistiram na determinação das massas do fruto $(\mathrm{g})$, da polpa $(\mathrm{g})$ e da casca $(\mathrm{g})$, comprimento e o diâmetro (mm) do fruto, relação comprimento/diâmetro, rendimento de polpa (\%), espessura da casca $(\mathrm{mm})$ e $\mathrm{n}^{\mathrm{o}}$ de sementes. As avaliações das doenças consistiram na determinação da incidência e severidade de bacteriose nos frutos, e de virose nas folhas, a partir de escalas de notas. ECL-7, Gigante Amarelo pl. 1 e MAR 20\#41 foram as três progênies com maiores valores para produtividade total estimada e para número de frutos. MSCA e Gigante Amarelo pl. 1 apresentaram as maiores produtividades de frutos de primeira enquanto MAR 20\#41 e Gigante Amarelo foram as que mostraram maiores produtividades de frutos 1B. Já para as classes $1 \mathrm{~A}$ e 2A, destinadas ao consumo in natura, a progênie MAR $20 \# 41$ obteve os melhores resultados. As progênies com menor incidência e severidade da virose do endurecimento dos frutos foram MAR 20\#21 e Gigante Amarelo pl. 1, respectivamente. Todos os materiais analisados foram classificados como moderadamente suscetíveis à virose do endurecimento do fruto. Para a bacteriose, as progênies Rosa Intenso e MSCA obtiveram as menores incidência e severidade, respectivamente. MSCA, Rosa Intenso, MAR 20\#41, Rubi Gigante e ECRAM 3 foram classificadas como resistentes e as demais progênies, como moderadamente suscetíveis. EC3-0 apresentou o maior comprimento de 
fruto, diferindo de ECL-7, que exibiu o menor valor para essa variável. Gigante Amarelo pl. 1 e MAR 20\#41 apresentaram, respectivamente, os maiores e os menores valores de diâmetro e relação comprimento/diâmetro. Os valores de rendimento variaram de 17,86\% (ECL-7) a 30,90\% (MAR 20\#21). Rubi Gigante, MAR 20\#21 e EC3-0 exibiram, respectivamente, os maiores valores para massa do fruto, massa da polpa e massa da casca, enquanto ECL-7 foi a progênie com os menores valores para essas variáveis. Observaram-se correlações de magnitude média e positiva entre a incidência e a severidade de bacteriose, e forte e positiva entre a incidência e a severidade da virose. Foram observadas correlações de magnitudes fortes e positivas entre as características: produção total/número total de frutos e quilogramas por hectare; número de frutos por planta e número de frutos por hectare.

Palavras-chave: Passiflora edulis Sims, produtividade, resistência a doenças. 


\section{AGRONOMIC EVALUATION AND REACTION OF 10 YELLOW PASSION FRUIT PROGENIES TO THE BACTERIAL SPOT DISEASE AND TO PASSION FRUIT WOODINESS VIRUS DISEASE UNDER FIELD CONDITIONS}

\section{ABSTRACT}

The lack of high yield and disease resistant varieties is a limiting factor to fruit quality and yield increment on passion fruit crop. The objective of this study was to evaluate the agronomic performance and the resistance of sour passion fruit to the bacterial spot disease (Xanthomonas axonopodis pv. passiflorae) and to the passion fruit woodiness virus disease (PWD) (Cowpea aphid-borne mosaic virus - CABMV), under field conditions, at Distrito Federal. The experiment consisted of a randomized block design comprised of ten treatments (progenies), three repetitions, and seven plants per parcel. Fruits coming from 40 harvesting were used for agronomic evaluation, which analyzed: estimated yield ( $\mathrm{kg} / \mathrm{ha})$, total number of fruits per hectare, mean fruit mass $(\mathrm{g})$, and fruit classification into five categories based on their equatorial diameter. Physical analyses consisted on the evaluation of fruit, pulp, and peel masses $(\mathrm{g})$, fruit length and diameter $(\mathrm{mm})$, fruit length/diameter ratio, pulp yield (\%), peel thickness $(\mathrm{mm})$, and seed number. Disease evaluations consisted on the determination of bacterial spot incidence and severity on fruits, and PWD on leaves, based on a grading scale. ECL-7, Gigante Amarelo pl. 1, and MAR 20\#41 were the progenies with greatest total estimated yields and fruit numbers. MSCA and Gigante Amarelo pl. 1 presented the highest yields for fruit type first whereas MAR 20\#41 and Gigante Amarelo pl. 1 were the progenies with greatest 1B fruit type yields. Progeny MAR 20\#41 showed the best performance for fruit types 1A and 2A, destined for in natura consumption. The progenies with the lowest PWD incidence and severity were MAR 20\#21 and Gigante Amarelo pl. 1, respectively. All materials tested were classified as moderately susceptible to PWD. For bacterial spot, progenies Rosa Intenso and MSCA showed the lowest disease incidence and severity, respectively. MSCA, Rosa Intenso, MAR 20\#41, Rubi Gigante, and ECRAM 3 were classified as resistant and the remaining progenies were classified as moderately susceptible. EC3-0 exhibited the highest fruit length, differing from ECL-7, which 
presented the lowest length. Gigante Amarelo pl. 1 and MAR $20 \# 41$ showed, respectively, the greatest and the lowest fruit diameter and length/diameter ratio. Pulp yield varied from $17.86 \%$ (ECL-7) to $30.90 \%$ (MAR 20\#21). Rubi Gigante, MAR 20\#21, and EC3-0 exhibited, respectively, the greatest fruit, pulp, and peel masses, whereas ECL7 revealed the lowest values for these variables. Medium and positive correlation was observed between the traits bacterial spot incidence and severity, and high and positive correlation was observed between the traits PWD incidence and severity. There was high and positive correlation for the following traits: total production/total number of fruits and kilograms per hectare; number of fruit per plant and number of fruit per hectare.

Keywords: Passiflora edulis Sims, yield, disease resistance. 


\section{INTRODUÇÃO}

$\mathrm{Na}$ fruticultura nacional, é possível encontrar algumas frutas que lançam o Brasil à posição de grande produtor mundial. O maracujá é uma das culturas que contribuem para a condição do país como grande produtor de frutas, sendo a produção estimada em 510.000 toneladas, com área cultivada correspondente a 41.500 hectares no decorrer da safra 2013/2014 (REVISTA CAMPO E NEGÓCIO, 2015).

A produtividade média brasileira é estimada em 13,42 toneladas ha/ano, entretanto, o potencial da cultura pode chegar a 50 toneladas ha/ano, através da utilização de cultivares melhoradas geneticamente e práticas de manejo da cultura (FALEIRO et al., 2011).

O maracujá tem adquirido grande importância no contexto mundial, notadamente a partir das últimas três décadas, sendo que o Brasil ocupa uma situação de destaque como maior produtor e consumidor mundial da fruta (FALEIRO et al., 2008).

O Brasil possui como principais Estados produtores de maracujá a Bahia (42,35\% da produção), o Ceará (25,52\% da produção), o Espirito Santo (5,73\% da produção), Minas Gerais (3,95\% da produção) e Sergipe (3,85\% da produção), sendo os demais estados responsáveis pelo restante da produção (18,60\%) (IBGE, 2015).

Nos últimos anos, a produção nacional foi insuficiente para abastecer o consumo interno do Brasil, havendo necessidade de importação de polpa de outros países para abastecer a indústria de sucos nacional (FERRAZ \& LOT, 2007).

O cultivo de variedades inadequadas, com baixa produtividade, é um dos principais fatores limitantes para a produção dessa cultura. A falta de genótipos altamente produtivos e a grande variabilidade existente em pomares comerciais indicam a necessidade de ações de pesquisa e desenvolvimento e transferência de tecnologia voltadas para o desenvolvimento e utilização de variedades melhoradas e tecnologias de produção capazes de proporcionar aumento da produtividade, possibilidade de aumento da sobrevida da cultura e melhoria da qualidade dos frutos (GONÇALVES et al., 2007; RUGGIERO, 2000).

Com o crescimento da cultura do maracujazeiro no país, muitas doenças como a bacteriose (Xanthomonas axonopodis pv. passiflorae) e virose do endurecimento do fruto (Cowpea aphid-borne mosaic virus - CABMV) apareceram e se tornaram limitantes ao seu cultivo, podendo provocar perdas totais. Até o momento, não tem sido observada, em 
níveis práticos, resistência ou tolerância a esses patógenos nas populações cultivadas (JUNQUEIRA et al., 2004).

No Brasil, grande parte dos programas de melhoramento está relacionada ao fruto, tanto no aspecto da produtividade, quanto na qualidade. Em termos qualitativos, considera-se que uma variedade in natura, desenvolvida para o mercado deve apresentar frutos grandes e ovais, a fim de conseguir boa classificação comercial, além de ter boa aparência, ser resistente ao transporte e à perda de qualidade durante o armazenamento e a comercialização (OLIVEIRA et al., 1994).

O melhoramento genético do maracujazeiro tem diversas finalidades em função do produto a ser considerado (frutos, folhas ou sementes) e da região de cultivo. $\mathrm{O}$ aumento da produtividade, a qualidade dos frutos, a resistência a doenças, aos nematoides e também o incremento na taxa de vingamento dos frutos são os principais objetivos do melhoramento da cultura (MELETTI et al., 2005).

Segundo DURIGAN et al. (2004) não existem normas ou regulamentos técnicos oficiais para a qualidade dos frutos do maracujá, apenas padrões relacionados ao diâmetro, peso, cor, textura, teor de sólidos solúveis e acidez. Outro índice, citado por esses autores, é a intensidade de coloração roxa ou amarela da casca: verde-maduro (coloração totalmente verde), meio maduros (cerca de $60 \%$ da casca verde) e frutos maduros (casca com coloração totalmente amarela ou roxa).

Diante do exposto, a seleção de progênies de maracujazeiro azedo que apresentem boa produtividade, qualidade de frutos e resistência a doenças é essencial para o desenvolvimento da cultura no país. Seguindo esse propósito, o presente trabalho teve como objetivo a avaliação do desempenho agronômico, análise física e também avaliação a fitopatógenos em 10 progênies de maracujazeiro azedo no Distrito Federal, sob condições de campo, visando ao uso dos mesmos em programas de melhoramento genético dessa cultura.

\section{MATERIAL E MÉTODOS}

\subsection{Local de desenvolvimento experimental}

O experimento foi implantado na Fazenda Água Limpa (FAL) da Universidade de Brasília (UnB), situada próxima a Vargem Bonita, com uma latitude de $16^{\circ} \mathrm{Sul}$, longitude 
de $48^{\circ}$ Oeste e $1.100 \mathrm{~m}$ de altitude. O clima da região é do tipo AW, caracterizado por chuvas concentradas no verão, de outubro a abril e invernos secos, de maio a setembro (MELO, 1999).

\subsection{Delineamento experimental}

O experimento de campo foi instalado em um solo tipo Latossolo VermelhoAmarelo, fase argilosa, profundo, com boa drenagem e baixa fertilidade natural. A calagem foi feita na área e $1 \mathrm{~kg}$ de superfosfato simples foi incorporado por cova em préplantio.

As mudas foram produzidas por meio de semeadura em bandejas de poliestireno (120 mL por célula) contendo substrato artificial à base de vermiculita, sob casa de vegetação localizada na Estação Experimental de Biologia - UnB. Em 28 de Abril de 2014 as mudas foram transplantadas para a área experimental. O espaçamento utilizado foi de 2,8 m entre linhas e $3 \mathrm{~m}$ entre plantas, totalizando 1.190 plantas por hectare.

O pomar foi conduzido utilizando o sistema de sustentação de espaldeira vertical, com os mourões distanciados de $6 \mathrm{~m}$ e 2 fios de arame liso ( $\left.\mathrm{n}^{\circ} 12\right)$, um a 1,6 m de altura e outro a 2,2 m em relação ao solo. As plantas foram conduzidas em haste única, tutoradas por barbante, até o arame superior, deixando para cada um dos fios de arame duas brotações laterais em sentidos opostos. Não foi realizada polinização manual e nem controle fitossanitário.

Foi utilizado o delineamento de blocos casualizados com 10 tratamentos (progênies), 7 plantas por parcela e 3 repetições, totalizando 210 plantas. Essas progênies, os mesmos utilizados no capítulo 1 , foram desenvolvidos a partir de trabalhos de pesquisa da Universidade de Brasília - UnB e Embrapa Cerrados.

As colheitas de frutos foram feitas recolhendo somente os frutos totalmente maduros. Para avaliação agronômica foram coletados todos os frutos que se encontravam ao chão em todas épocas de avaliação, e para avaliação de doenças, Xanthomonas axonopodis pv. passiflorae e Cowpea aphid-borne mosaic virus (CABMV), foram selecionados ao acaso 20 frutos por parcela, totalizando 60 frutos por genótipo para a primeira e para a segunda foram avaliadas as plantas no campo, sendo que cada parcela recebeu 20 notas (10 notas de cada lado). Cada parcela do experimento foi colhida separadamente em caixas de plástico e identificadas de acordo com o croqui da área experimental. 


\subsection{Avaliação agronômica}

As avaliações de desempenho agronômico foram realizadas de 27 de janeiro a 24 de novembro de 2015, totalizando 40 colheitas nos 10 meses de avaliação. As colheitas foram realizadas coletando frutos com ponto de maturação total. Cada parcela do experimento foi colhida separadamente em caixas de plástico devidamente identificadas.

O procedimento de pesagem foi realizado semanalmente durante todo o período de análise. As variáveis analisadas foram: produtividade estimada $(\mathrm{kg} / \mathrm{ha})$, considerandose 1190 plantas por hectare, número total de frutos por hectare, peso total por planta $(\mathrm{kg})$, classificação dos frutos quanto ao diâmetro equatorial em cinco categorias, segundo RANGEL (2002), onde: Primeira - frutos com diâmetro equatorial igual ou menor que $55 \mathrm{~mm}$; 1B - igual ou maior que 55 até $65 \mathrm{~mm}$; 1A - Igual ou maior que 65 até $75 \mathrm{~mm}$; 2A - igual ou maior que 75 até $90 \mathrm{~mm}, 3 \mathrm{~A}$ - maior que $90 \mathrm{~mm}$ (Tabela 1).

Tabela 1. Classificação dos frutos de maracujazeiro azedo (Passiflora edulis Sims) de acordo com o seu diâmetro equatorial $(\mathrm{mm})$, utilizada na avaliação de 10 progênies cultivados na Fazenda Água Limpa UnB, Brasília, 2014 a 2015, segundo proposta de RANGEL (2002).

\section{Classificação Diâmetro Equatorial (mm)}

Primeira Diâmetro menor que 55

$1 \mathrm{~B}$

Diâmetro do fruto maior que 55 e menor que 65

$1 \mathrm{~A}$

Diâmetro maior que 65 e menor do que 75

$2 \mathrm{~A}$

Diâmetro maior que 75 e menor que 90

$3 \mathrm{~A}$

Diâmetro maior que 90

\subsection{Avaliação de doenças}

A identificação visual do sintoma das doenças se deve à percepção e à quantificação de lesões na superfície do fruto, para bacteriose, e nas folhas para virose.

O período de avaliações decorreu de março a maio de 2015, em frequência mensal, utilizando a margem de representação de 20 frutos/folhas por parcela. Não houve inoculação de doenças, sendo considerada a pressão de inoculo natural, sob condições de campo. 
A incidência e a severidade da bacteriose (Xanthomonas axonopodis pv. passiflorae) foram estimadas de acordo com uma escala de notas desenvolvida por JUNQUEIRA et al. (2003), onde nota 1: frutos não apresentam sintomas de doenças, sendo o genótipo considerado resistente $(\mathrm{R})$; nota 2 : os frutos apresentam até $10 \%$ da superfície coberta por lesões, sendo o genótipo considerado moderadamente resistente (MR); nota 3: frutos apresentam de 10,01 a 30\% da superfície coberta por lesões, sendo o genótipo considerado susceptível (S) e nota 4: frutos apresentam mais de 30,01\% da superfície coberta por lesões, sendo o genótipo considerado altamente susceptível (AS) (Tabela 2).

Baseando-se nas notas médias (NM) obtidas através da escala, as plantas foram classificadas em: resistentes $(\mathrm{R}), 1 \leq \mathrm{NM} \leq 1.5$; moderadamente suscetíveis (MS), 1.51 $<\mathrm{NM} \leq 2.5$; suscetíveis (S), $2.51<\mathrm{NM} \leq 3.5$; e altamente suscetíveis (AS), $3.51<\mathrm{NM} \leq$ 4.

Tabela 2. Classificação de incidência e a severidade (\%), utilizada na avaliação de bacteriose (Xanthomonas axonopodis pv. passiflorae) em 10 progênies de maracujazeiro azedo (Passiflora edulis Sims) cultivados na Fazenda Água Limpa - UnB, Brasília, 2015, segundo proposta de JUNQUEIRA et al. (2003).

Nota Sintomatologia vegetal

\section{Severidade} média

\section{Grau de} resistência

\begin{tabular}{llcl}
\hline 1 & $\begin{array}{l}\text { Frutos não apresentam sintomas de } \\
\text { doenças }\end{array}$ & $1-1,5$ & Resistentes (R) \\
2 & $\begin{array}{l}\text { Frutos apresentam até } 10 \% \text { da } \\
\text { superfície coberta por lesões }\end{array}$ & $1,51-2,5$ & Moderadamente \\
& Fuscetíveis (MS) & & \\
3 & Frutos apresentam de 10,01 a 30\% & $2,51-3,5$ & Suscetíveis (S) \\
& da superfície coberta por lesões & & \\
4 & Frutos apresentam mais de 30,01\% & $3,51-4,0$ & Altamente \\
& da superfície coberta por lesões & & suscetíveis (AS) \\
\hline
\end{tabular}

Para a avaliação do vírus (Cowpea aphid-borne mosaic virus-CABMV) nas plantas de maracujá no campo seguiu-se a metodologia proposta por SOUSA (2005) onde 
avalia-se a severidade e incidência coletando-se 20 folhas, na extremidade superior dos ramos excluindo as folhas mais novas e com ataque de ácaro, em espaços regulares (10 folhas em cada lado da parcela) e atribuindo notas de 1 a 4, de acordo com a Tabela 3. Com base nas médias das notas encontradas, obteve-se o índice de severidade à virose do endurecimento dos frutos a qual foi utilizada para identificar o grau de resistência da progênie à virose.

Tabela 3. Notas e sintomas visuais utilizados para análise das folhas na avaliação da virose do endurecimento dos frutos (Cowpea aphid-borne mosaic virus) em 10 progênies de maracujazeiro azedo (Passiflora edulis Sims) cultivados na Fazenda Água Limpa - UnB, Brasília, 2015, segundo proposta de SOUSA (2005).

\begin{tabular}{clcc}
\hline Nota & Sintomatologia vegetal & $\begin{array}{c}\text { Severidade } \\
\text { média }\end{array}$ & Grau de resistência \\
\hline 1 & Folha sem sintoma de mosaico & $1-1,5$ & Resistente (R) \\
2 & $\begin{array}{l}\text { Folha apresentando mosaico leve } \\
\text { e sem deformações foliares }\end{array}$ & $1,51-2,5$ & Moderadamente \\
& & & Suscetível (MS) \\
3 & $\begin{array}{l}\text { Folha apresentando mosaico leve, } \\
\text { deformações na superfície das }\end{array}$ & $2,51-3,5$ & Suscetível (S) \\
& folhas (parecido com bolhas) & & Altamente suscetível \\
& Folha apresentando mosaico & $3,51-4,0$ & (AS) \\
& severo, deformações na superfície & & \\
& das folhas e do limbo foliar & &
\end{tabular}

\subsection{Análises físicas}

\subsubsection{Determinação da massa, comprimento e diâmetro do fruto}

Inicialmente, os 5 frutos de cada amostra foram pesados em balança digital da marca FILIZOLA, com precisão de $0,01 \mathrm{~g}$, para estimativa da massa média dos frutos (MASSA F) (kg). O comprimento do fruto (COMP) (mm) foi tomado medindo-se a distância compreendida entre a base (inserção do pedúnculo) e o ápice. $\mathrm{O}$ diâmetro do fruto (DIAM) (mm) foi tomado perpendicular à altura na região de maior dimensão do fruto. Tais medidas foram feitas com auxílio de um paquímetro digital, da marca 
Mitutoyo, com precisão de 0,01 mm e, em seguida, foram estimados os valores da relação comprimento/diâmetro (C/D).

\subsubsection{Determinação do rendimento de polpa, massa de polpa e casca, espessura da casca e número de sementes}

Os frutos foram despolpados e, com auxílio de uma balança analítica, foram determinadas a massa da polpa acrescida de sementes (MASSA P) (g) e a massa da casca

(MASSA C) (g). O rendimento de polpa (REND) (\%) foi obtido pela relação massa da polpa e massa do fruto. A espessura da casca $(\mathrm{EC})(\mathrm{mm})$ foi medida na região equatorial do fruto, com auxílio de um paquímetro digital. As sementes, depois de separadas da polpa, serão submetidas à secagem em estufa a $50^{\circ} \mathrm{C}$ e contadas manualmente.

\section{RESULTADOS E DISCUSSÃO}

\subsection{Avaliação agronômica}

Não foi possível observar diferenças estatísticas significativas nas variáveis resposta referente à avaliação agronômica (produtividade estimada, número total de frutos por hectare, classificação dos frutos quanto ao diâmetro equatorial) ao longo das 40 colheitas. No entanto, foi possível verificar que para produtividade total estimada, a progênie ECL-7 obteve a maior produtividade com 19.999,27 kg/ha, seguida de Gigante Amarelo pl. 1, com 19.472,06 kg/ha e MAR 20\#41 com 17.407,94 kg/ha. Dessa forma, foi possível verificar que essas progênies se comportaram de forma superior no quesito produtividade total, visto que, segundo dados do IBGE, a produtividade média brasileira é estimada em 13,42 toneladas ha/ano (IBGE, 2012). Há de se ressaltar que as progênies foram conduzidas e avaliadas em condições de ausência total de controle fitossanitário de doenças e sem o emprego de polinização manual, sendo ambos manejos realizados rotineiramente por produtores de maracujá. Em contrapartida, as progênies MAR 20\#24 pl.2, MAR 20\#21 e Rubi Gigante apresentaram as menores produtividades, com 6.750,84 $\mathrm{kg} / \mathrm{ha}, 7.634,47 \mathrm{~kg} / \mathrm{ha}$ e $8.674,27 \mathrm{~kg} / \mathrm{ha}$, respectivamente. Para o número total de frutos, a progênie Gigante Amarelo pl. 1 obteve o melhor resultado com 155.625,55 frutos/ha, 
seguida da ECL-7 (149.411,11 frutos/ha) e MAR 20\#41 (143.230,66 frutos/ha) (Tabela $4)$.

Tabela 4. Produtividade total estimada e número total de frutos por hectare de 10 progênies de maracujazeiro azedo (Passiflora edulis Sims) cultivadas na Fazenda Água Limpa durante 40 colheitas. Brasília, Dez/2014 - Jun/2015.

\begin{tabular}{lll}
\hline Progênie & $\begin{array}{l}\text { Produtividade total } \\
\text { estimada kg/ha }\end{array}$ & $\begin{array}{l}\text { Número total de } \\
\text { frutos/ha }\end{array}$ \\
Mar 20\#24 pl.2 & $6.750,84 \mathrm{a}$ & $52.992,77 \mathrm{a}$ \\
Rubi Gigante & $8.674,27 \mathrm{a}$ & $72.034,66 \mathrm{a}$ \\
Rosa Intenso & $12.367,04 \mathrm{a}$ & $98.260,00 \mathrm{a}$ \\
EC-RAM 3 & $10.546,56 \mathrm{a}$ & $93.726,66 \mathrm{a}$ \\
Mar 20\#21 & $7.634,47 \mathrm{a}$ & $58.440,33 \mathrm{a}$ \\
EC3-0 & $13.168,83 \mathrm{a}$ & $106.462,50 \mathrm{a}$ \\
Mar 20\#41 & $17.407,94 \mathrm{a}$ & $143.230,66 \mathrm{a}$ \\
Gig Amarelo pl.1 & $19.472,06 \mathrm{a}$ & $155.625,55 \mathrm{a}$ \\
\hline ECL 7 & $19.999,27 \mathrm{a}$ & $149.411,11 \mathrm{a}$ \\
\hline MSCA & $13.951,07 \mathrm{a}$ & $124.725,22 \mathrm{a}$ \\
\hline dias seguidas pelas mesmas letras não diferem entre si pelo teste de Tukey ao nível de 5\%.
\end{tabular}

VILELA (2013), avaliando a produtividade estimada ( $\mathrm{kg} / \mathrm{ha})$, ao longo de 28 colheitas, verificou a maior produtividade e a maior quantidade de frutos por hectare para frutos de primeira nas progênies MAR 20\#21 e BRS Gigante Amarelo, diferentemente do observado no presente trabalho, onde a progênie MAR20\#21 não ficou entre as mais produtivas e a MSCA obteve a maior produção de frutos de primeira, porém não obteve a maior produtividade e a progênies Gigante Amarelo pl. 1 obteve a segunda maior produtividade e também produção de frutos de primeira. Ainda no trabalho de VILELA (2013), a maior produtividade de frutos 1A foi observada nas progênies PLANTA 7 e AR01, 19.601 frutos e $4.226 \mathrm{~kg} ; 18.770$ frutos e $3.970 \mathrm{~kg}$, respectivamente e a menor produtividade nessa classe ficou com EC3-0 (626 kg/ha) e os frutos classificados como $2 \mathrm{~A}$ e $3 \mathrm{~A}$, apresentaram baixas produtividades estimadas.

Cinco progênies avaliadas neste trabalho também foram testadas por MOREIRA (2011) que, em 20 colheitas, obteve resultados semelhantes, considerando a progênie Gigante Amarelo como a mais produtiva de frutos de primeira $(3.343 \mathrm{~kg} / \mathrm{ha} ; 53.939$ frutos/ha). Entretanto, diferente do presente trabalho, a progênie EC3-0 apresentou um dos menores índices de produtividade $(4.055 \mathrm{~kg} / \mathrm{ha})$.

GONÇALVES (2011), avaliando a produtividade total estimada em 26 progênies de maracujazeiro amarelo, ao longo de 56 colheitas, considerou a progênie MAR 20\#41 
como uma das menos produtivas $(21.831 \mathrm{~kg} / \mathrm{ha})$, porém, sua produtividade ainda foi maior do que a observada neste trabalho $(17.407 \mathrm{~kg} / \mathrm{ha})$.

Para frutos 1A, as progênies MAR 20\#41 e Gigante amarelo pl.1 se destacaram, obtendo o maior número de frutos e maior produção (Tabela 5). Já para frutos classificados como 2A, se destacaram as progênies MAR 20\#41 e ECL-7. Para os frutos 3A, as progênies Gigante amarelo pl.1 e a ECL-7 obtiveram a produção e número de frutos, na média das 3 parcelas avaliadas de cada progênie (Tabela 5).

\subsection{Avaliação de doenças}

Ao realizar a análise de variância para incidência e severidade da bacteriose e virose do endurecimento do fruto das 10 progênies em estudo, não foi possível encontrar diferenças estatísticas pelo teste $\mathrm{F}$ ( $5 \%$ de probabilidade). Os coeficientes de variação variaram de $12 \%$ a $26 \%$, demonstrando confiabilidade dos dados e boa precisão experimental (Tabela 6).

Tabela 6. Avaliação de incidência e severidade da bacteriose e virose em 10 progênies de maracujazeiro azedo (Passiflora edulis Sims) cultivadas na Fazenda Água Limpa, durante 3 avaliações. Brasília, MarMai de 2015.

\begin{tabular}{lcccc}
\hline Parâmetros & Bactéria & \multicolumn{3}{c}{ Vírus } \\
\hline & Incidência & Severidade & Incidência & Severidade \\
F & $1,48^{\text {ns }}$ & $1,55^{\mathrm{ns}}$ & $1,2^{\mathrm{ns}}$ & $1,28^{\mathrm{ns}}$ \\
CV\% & $26,91 \%$ & $24,14 \%$ & $15,66 \%$ & $12,33 \%$ \\
Herdabilidade & 32,51 & 35,47 & 16,53 & 22,01 \\
CVg & 10,78 & 10,33 & 4,02 & 3,78 \\
CVg/Cve & 0,4 & 0,428 & 0,256 & 0,306 \\
\hline
\end{tabular}

F: teste F (5\% de probabilidade), CV: \% coeficiente de variação, CVg: \%, coeficiente de variação genético, $\mathrm{CVg} / \mathrm{CVe}$ \% e razão entre coeficiente e variação genético e ambiental. 
Tabela 5. Avaliação agronômica de 10 progênies de maracujazeiro azedo (Passiflora edulis Sims) cultivadas na Fazenda Água Limpa durante 40 colheitas. Brasília, Dez/2014 - Jun/2015.

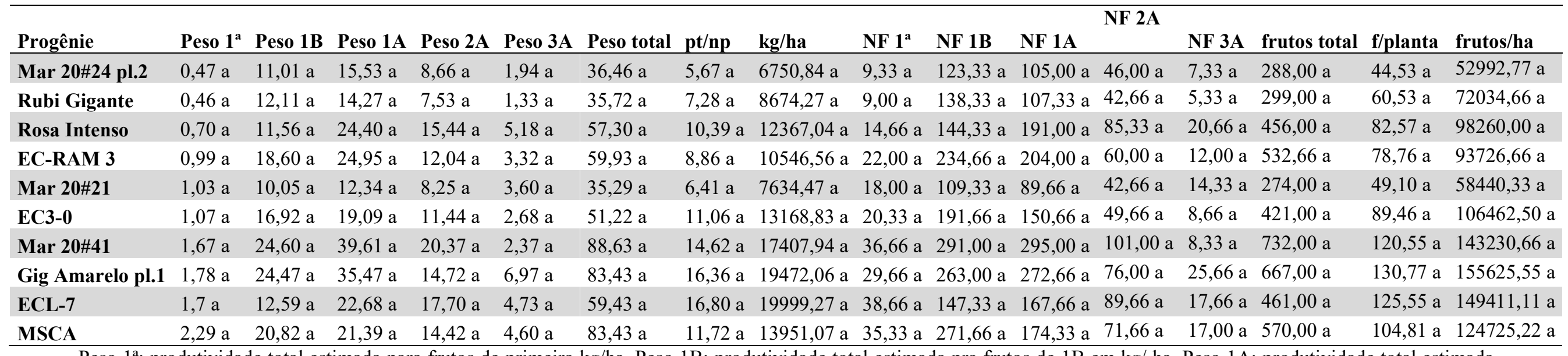

Peso $1^{\text {a }}$ : produtividade total estimada para frutos de primeira kg/ha, Peso 1B: produtividade total estimada pra frutos de $1 \mathrm{~B}$ em $\mathrm{kg} / \mathrm{ha}$, Peso $1 \mathrm{~A}$ : produtividade total estimada para frutos $1 \mathrm{~A} \mathrm{em} \mathrm{kg} / \mathrm{ha}$, Peso 2A: produtividade total estimada para frutos $2 \mathrm{~A} \mathrm{em} \mathrm{kg} / \mathrm{ha}$, Peso $3 \mathrm{~A}$ : produtividade total estimada para frutos $3 \mathrm{~A}$ em $\mathrm{kg} / \mathrm{ha}$, Peso total: produtividade total estimada, pt/np: produtividade total/ $\mathrm{n}^{\mathrm{o}}$ de plantas, $\mathrm{kg} / \mathrm{ha}$ : peso por ha, $\mathrm{NF} 1^{\mathrm{a}}$ : número total de frutos de primeira/ ha, NF $1 \mathrm{~B}$ : número total de frutos $1 \mathrm{~B} / \mathrm{ha}$, NF $1 \mathrm{~A}$ : número total de frutos $1 \mathrm{~A} /$ ha, NF 2A: número total de frutos $2 \mathrm{~A} /$ ha, NF 3A: número total de frutos 3A/ha, F/planta: fruto/planta, F/ha: fruto/ha. Médias seguidas pelas mesmas letras não diferem entre si pelo teste de Tukey ao nível de $5 \%$. 
Para incidência da bacteriose, as progênies que apresentaram as maiores médias foram EC3-0, MAR 20\#21 e MSCA (67,5\%; 54,5\% e 54,4\% respectivamente). A progênie Rosa Intenso foi o que apresentou menor valor de incidência a bacteriose $(36,1 \%)$ (Tabela 7). No que se refere à severidade da bacteriose das progênies estudadas, 5 foram consideradas resistente e outras 5 moderadamente suscetível segundo a escala de notas desenvolvida por JUNQUEIRA et al. (2003). A progênie que apresentou maior nota foi a EC3-0 $(1,84)$ e a menor o MSCA $(1,08)$ (Tabela 7$)$.

Tabela 7. Incidência, severidade e grau de resistência de 10 progênies à bacteriose (Xanthomonas axonopodis pv. passiflorae) em folhas de maracujazeiro azedo (Passiflora edulis Sims) cultivadas na Fazenda Água Limpa durante 3 avaliações. Brasília, Mar- Mai de 2015.

\begin{tabular}{lccc}
\hline Progênie & Incidência & Severidade & Classificação \\
\hline EC3-0 & $67,5 \mathrm{a}$ & $1,84 \mathrm{a}$ & $\mathrm{MS}$ \\
ECL-7 & $49,1 \mathrm{a}$ & $1,56 \mathrm{a}$ & $\mathrm{MS}$ \\
EC-RAM 3 & $46,87 \mathrm{a}$ & $1,48 \mathrm{a}$ & $\mathrm{R}$ \\
Gig Amarelo pl1 & $52,14 \mathrm{a}$ & $1,68 \mathrm{a}$ & $\mathrm{MS}$ \\
Mar 20\#21 & $54,58 \mathrm{a}$ & $1,71 \mathrm{a}$ & $\mathrm{MS}$ \\
Mar 20\#24 pl2 & $52,84 \mathrm{a}$ & $1,59 \mathrm{a}$ & $\mathrm{MS}$ \\
Mar 20\#41 & $37,5 \mathrm{a}$ & $1,24 \mathrm{a}$ & $\mathrm{R}$ \\
MSCA & $54,44 \mathrm{a}$ & $1,08 \mathrm{a}$ & $\mathrm{R}$ \\
Rosa Intenso & $36,17 \mathrm{a}$ & $1,18 \mathrm{a}$ & $\mathrm{R}$ \\
Rubi Gigante & $41,66 \mathrm{a}$ & $1,31 \mathrm{a}$ & $\mathrm{R}$ \\
\hline
\end{tabular}

* Médias seguidas pelas mesmas letras não diferem entre si pelo teste de Tukey ao nível de $5 \%$ de probabilidade.

As progênies MSCA, EC-RAM 3 e Rosa Intenso que apresentaram os maiores resultados $(78,33 \%, 71,67 \%$ e $71,67 \%$ respectivamente) e a progênie MAR 20\#21 o menor valor de incidência a virose $(56,67 \%)$ (Tabela 8$)$.

As maiores notas de severidade foram obtidas nas progênies EC-RAM $3(2,18)$, Rosa Intenso $(2,17)$ e ECL-7 $(2,09)$ e a menor na Gigante Amarelo pl. $1(1,87)$.

Corroborando com o presente trabalho, CASTRO (2015), em trabalho realizado em campo experimental do Distrito Federal, verificou que nas avaliações das progênies de maracujazeiro azedo à bacteriose e virose observou-se que a maioria das progênies se apresentou medianamente suscetível a virose e moderadamente resistente à bacteriose. 
Tabela 8. Incidência, severidade e grau de resistência de 10 progênies à virose do endurecimento dos frutos (Cowpea aphid-borne mosaic virus) em folhas de maracujazeiro azedo (Passiflora edulis Sims) cultivadas na Fazenda Água Limpa durante 3 avaliações. Brasília, Mar- Mai de 2015.

\begin{tabular}{lccc}
\hline Progênie & Incidência & Severidade & Classificação \\
\hline EC3-0 & $65 \mathrm{a}$ & $2,1 \mathrm{a}$ & MS \\
ECL-7 & $71,4 \mathrm{a}$ & $2,09 \mathrm{a}$ & $\mathrm{MS}$ \\
EC-RAM 3 & $71,67 \mathrm{a}$ & $2,18 \mathrm{a}$ & $\mathrm{MS}$ \\
Gig Amarelo pl1 & $60 \mathrm{a}$ & $1,87 \mathrm{a}$ & MS \\
Mar 20\#21 & $56,67 \mathrm{a}$ & $1,9 \mathrm{a}$ & $\mathrm{MS}$ \\
Mar 20\#24 pl2 & $63,33 \mathrm{a}$ & $2,02 \mathrm{a}$ & $\mathrm{MS}$ \\
Mar 20\#41 & $61,67 \mathrm{a}$ & $1,87 \mathrm{a}$ & MS \\
MSCA & $78,33 \mathrm{a}$ & $2,4 \mathrm{a}$ & MS \\
Rosa Intenso & $71,67 \mathrm{a}$ & $2,17 \mathrm{a}$ & MS \\
Rubi Gigante & $66,67 \mathrm{a}$ & $2,02 \mathrm{a}$ & MS \\
\hline
\end{tabular}

* Médias seguidas pelas mesmas letras não diferem entre si pelo teste de Tukey ao nível de $5 \%$ de probabilidade.

Associado às avaliações agronômicas para estudo das melhores progênies a serem selecionadas no programa de melhoramento de maracujá azedo, o estudo sobre a incidência e severidade de doenças representa ponto importante na manutenção dos pomares de maracujá do Brasil. Verifica-se nos trabalhos que estão sendo desenvolvidos nos últimos anos, a dificuldade do desenvolvimento de materiais de maracujá azedo com resistência principalmente a viroses (CASTRO, 2015; KOSOSKI, 2014; VIANA, 2007). Dessa forma, existe a necessidade de diversificar os estudos sobre viroses no maracujazeiro, com introdução de outros materiais genéticos de Passiflora, screening com diferentes isolados e diferentes técnicas de inoculação, entre outras medidas experimentais que possam proporcionar resultados promissores.

No trabalho de CASTRO (2015), foram observadas diferença estatísticas quanto à incidência e severidade da bacteriose em 4 épocas de avaliação. Em uma mesma época foi observado $100 \%$ de frutos atacados em algumas progênies e $0 \%$ em outras progênies.

Avaliando 26 progênies em campo, VILELA (2013), também não observou diferenças estatísticas pelo teste $\mathrm{F}$, a $5 \%$ de probabilidade, entre as progênies de maracujá para severidade e incidência da bacteriose. As estimativas de herdabilidade para severidade e incidência foram semelhantes $(25,97 \%$ e $35,55 \%$ respectivamente) ao presente trabalho. Esses valores de herdabilidade são comuns em avaliação de doença em condições de campo, e, em conjunto com os valores encontrados nas relações $\mathrm{CVg} / \mathrm{CVe}$, indicam que métodos de melhoramento como seleção massal podem ser ineficientes para o desenvolvimento de materiais resistentes a bacteriose. 
GONÇALVES (2011) obteve maior severidade média com a progênie MAR $20 \# 40(2,67)$ e a menor em MAR 20\#21 $(2,10)$. A maior incidência média foi obtida pelo mesmo autor em MAR $20 \# 49(87,18 \%)$ e a menor em MAR $20 \# 15$ (71,56\%). Enquanto no presente trabalho a progênie MAR 20\#21 obteve média de severidade inferior $(1,9)$ e as progênies Gigante Amarelo pl. 1 e MAR 20\#41 obtiveram as menores medias de severidade do vírus do endurecimento dos frutos 1,87 e 1,87 respectivamente.

\subsection{Análises físicas}

A partir da análise de dados referente à análise física, as variáveis resposta COMP, DIAM, C/D, REND, MASSA F, MASSA P e MASSA C apresentaram significância na análise de variância (Teste F, 5\% de probabilidade), demonstrando que os genótipos diferiram entre si em pelo menos um par de comparação. Além disso, a partir dos valores dos coeficientes de variação que variaram de $3,27 \%$ a 33,92\%, verifica-se boa precisão experimental.

A partir do teste Tukey ( $5 \%$ de probabilidade), a variável COMP foi dividida nos grupos a e b, sendo encontrado genótipos intermediários que apresentaram letras ab. As progênies que se destacaram com maiores comprimentos de frutos foram os EC3-0, Rubi Gigante e MAR 20\#24 pl.2, diferido do ECL-7, com menor comprimento observado (Tabela 10).

Tabela 9. Variáveis significativas das análises físicas de 10 progênies de maracujazeiro azedo (Passiflora edulis Sims) cultivadas na Fazenda Água Limpa. Brasília, 2015.

\begin{tabular}{lccccccc}
\hline Parâmetros & COMP(mm) & DIAM(mm) & C/D & $\begin{array}{c}\text { RENDP } \\
(\%)\end{array}$ & $\begin{array}{c}\text { M FRUT } \\
(\mathbf{g})\end{array}$ & M POLP (g) & M CASC (g) \\
\hline F & $3,87^{* *}$ & $2,64 *$ & $8,68^{* *}$ & $3,29 *$ & $2,58^{*}$ & $3,04 *$ & $2,89^{*}$ \\
CV\% & 7,18 & 80,04 & 3,27 & 18,65 & 23,31 & 33,92 & 19,44 \\
Herdabilidade & 74,16 & 62,05 & 88,47 & 69,66 & 61,3 & 67,18 & 65,49 \\
CVg & 7,03 & 5,94 & 5,24 & 16,31 & 16,94 & 28,02 & 15,46 \\
CVg/Cve & 0,978 & 0,738 & 1,599 & 0,875 & 0,726 & 0,826 & 0,795 \\
\hline
\end{tabular}

*Significativo no teste F a 5\% de probabilidade; ** Significativo no teste F a 1\% e a 5\% de probabilidade. COMP: comprimento médio do fruto (mm); DIAM: diâmetro médio do fruto (mm); C/D: relação comprimento e diâmetro dos frutos; RENDP: rendimento de polpa, expresso em porcentagem; M FRUT: massa do fruto; M POLP: massa de polpa; M CASC: massa de casca. 
Tabela 10. Média das variáveis significativas das análises físicas de 10 progênies de maracujazeiro azedo (Passiflora edulis Sims) cultivadas na Fazenda Água Limpa. Brasília, 2015.

\begin{tabular}{|c|c|c|c|c|c|c|c|}
\hline Parâmetros & COMP(mm) & $\operatorname{DIAM}(\mathbf{m m})$ & C/D & $\begin{array}{c}\text { RENDP } \\
(\%)\end{array}$ & M FRUT (g) & M POLP (g) & $\begin{array}{c}\text { M CASC } \\
(\mathrm{g})\end{array}$ \\
\hline EC3-0 & $81,08 \mathrm{a}$ & $68,77 \mathrm{a}$ & $1,17 \mathrm{a}$ & 20,17 a & $135,47 \mathrm{a}$ & $28,94 \mathrm{a}$ & $106,67 \mathrm{a}$ \\
\hline ECL-7 & $60,29 \mathrm{~b}$ & 58,19 a & $1,04 \mathrm{~cd}$ & $17,83 \mathrm{a}$ & 73,07 a & $13,97 \mathrm{a}$ & $58,67 \mathrm{a}$ \\
\hline EC-RAM 3 & $70,99 \mathrm{ab}$ & $65,68 \mathrm{a}$ & $\begin{array}{l}1,08 \\
\text { abcd }\end{array}$ & $30,46 \mathrm{a}$ & $116,33 \mathrm{a}$ & $36,03 \mathrm{a}$ & $82,33 \mathrm{a}$ \\
\hline Gig. Amarelo pl. 1 & $66,8 \mathrm{ab}$ & $56,76 \mathrm{a}$ & $1,18 \mathrm{a}$ & $20,84 \mathrm{a}$ & $78,4 \mathrm{a}$ & $17,02 \mathrm{a}$ & $60,67 \mathrm{a}$ \\
\hline Mar 20\#21 & $73,27 \mathrm{ab}$ & $69,62 \mathrm{a}$ & $1,05 \mathrm{~cd}$ & $30,90 \mathrm{a}$ & $131,47 \mathrm{a}$ & $40,76 \mathrm{a}$ & $95,33 \mathrm{a}$ \\
\hline Mar 20\#24 pl. 2 & 76,63 a & $67,13 \mathrm{a}$ & $\begin{array}{l}1,14 \\
\text { abc }\end{array}$ & $23,82 \mathrm{a}$ & $125,87 \mathrm{a}$ & $29,5 \mathrm{a}$ & $92 \mathrm{a}$ \\
\hline Mar 20\#41 & $72,99 \mathrm{ab}$ & $70,88 \mathrm{a}$ & $1,02 \mathrm{~d}$ & $28,38 \mathrm{a}$ & $136,53 \mathrm{a}$ & $38,79 \mathrm{a}$ & 98,33 a \\
\hline MSCA & $71,78 \mathrm{ab}$ & $67,21 \mathrm{a}$ & $\begin{array}{l}1,07 \\
\text { bcd }\end{array}$ & $28,79 \mathrm{a}$ & $124,93 \mathrm{a}$ & $35,91 \mathrm{a}$ & 88,67 a \\
\hline Rosa Intenso & $70,84 \mathrm{ab}$ & $60,63 \mathrm{a}$ & $1,17 \mathrm{ab}$ & $19,05 \mathrm{a}$ & $91,87 \mathrm{a}$ & $17,11 \mathrm{a}$ & $75,67 \mathrm{a}$ \\
\hline Rubi Gigante & $78,4 \mathrm{a}$ & $67,08 \mathrm{a}$ & $1,17 \mathrm{ab}$ & $25,41 \mathrm{a}$ & $139,47 \mathrm{a}$ & $38,22 \mathrm{a}$ & $100,33 \mathrm{a}$ \\
\hline
\end{tabular}

Ao verificar os valores dos parâmetros genéticos referente à variável COMP, observou-se valor de herdabilidade no sentido amplo de $74,16 \%$ e valor da relação $\mathrm{CVg} / \mathrm{CVe}$ de 0,97 (Tabela 9). Esses valores indicam que para essa variável, métodos simples de seleção como a seleção massal, podem proporcionar bons resultados nos próximos ciclos de seleção, visto que o efeito do ambiente não foi muito superior ao efeito genético na característica (ROCHA, 2014; ALVES, 2004). Não foram observadas diferenças significativas entre as progênies quanto ao diâmetro dos frutos.

Segundo FORTALEZA et al. (2005), tanto o diâmetro do fruto quanto o comprimento, são características relacionadas ao número de sementes e ao rendimento de polpa. Dessa forma, o estudo dessas características é muito importante no desenvolvimento de materiais mais promissores tanto para indústria como para a comercialização de frutos in natura.

A variável C/D apresentou resultados relevantes no teste de médias, sendo que as progênies diferiram entre si, com a formação de diferentes grupos (Tabela 10). A progênie que apresentou maior de C/D foi Gigante Amarelo pl. 1 (1,18), diferindo da progênie MAR 20\#41 que apresentou valor de 1,02. É importante salientar que valores acima de 1 dessa relação C/D indicam frutos com formato oval. Segundo FARIAS et al. (2005), a relação $\mathrm{C} / \mathrm{D}$ representa importância na cultura do maracujá por estar relacionada ao 
formato dos frutos. Dessa forma, valores iguais a 1 representam frutos redondos, sendo que os valores maiores que 1 representam frutos ovais. Os frutos ovais normalmente estão relacionados a um maior rendimento de polpa e, dessa forma, são preferidos em detrimento dos frutos redondos (NEGREIROS et al., 2008; MANICA, 1981). Além disso, o valor de herdabilidade para essa característica foi de $88,47 \%$, um valor alto, aliado a um alto valor da relação $\mathrm{CVg} / \mathrm{CVe}(1,59)$, indicando baixa interferência do ambiente na expressão genética. Portanto, é possível trabalhar com métodos simples de seleção para o desenvolvimento de matérias superiores (ROCHA, 2014). Aliado a isso, as progênies estudadas nesse trabalho poderiam ser selecionadas a partir dessa característica com boa possibilidade de êxito para aumento de rendimento de polpa.

Apesar da significância da análise de variância, as médias da variável REND não apresentaram diferenças estatísticas entre si, pelo teste de Tukey a 5\% de probabilidade. Os valores de rendimento variaram de 17,86 \% (ECL-7) a 30,90\% (MAR 20\#21) gramas (Tabela 10). No entanto, os parâmetros genéticos dessa característica foram interessantes do ponto do melhoramento de plantas, onde a herdabilidade teve uma porcentagem mediana, de $69,66 \%$ e a relação entre o $\mathrm{CVg} / \mathrm{CVe}$ foi próxima de $1(0,87)$, o que revela condição favorável a seleção (Tabela 9).

Para o rendimento de polpa, outros trabalhos demonstraram resultados superiores, com progênies de maracujazeiro azedo derivadas dessas estudadas no presente trabalho. A exemplo disso, GRECO (2014), analisando 32 progênies de maracujazeiro azedo quanto as características físicas no Distrito Federal, obteve rendimento de polpa superior a 38,7\% e as progênies que se destacaram para essa característica foram: EC-R (46,6\%), MAR $20 \# 6$ (45,1\%), MAR $20 \# 39(43,6 \%)$ e MAR $20 \# 40(43,4 \%)$ sendo que EC-R e MAR $20 \# 6$ também apresentaram maior número de sementes por fruto. No entanto, no trabalho desenvolvido por GRECO (2014), a partir da análise dos coeficientes de herdabilidade no sentido amplo ficou evidenciada variância ambiental pronunciada para as características avaliadas, diferindo do ocorrido no presente estudo. Os valores mais baixos de rendimento de fruto podem estar relacionados ao fato do pomar experimental estar em final de ciclo, próximo de dois anos do plantio. Dessa forma, nessa etapa, verifica-se maior índice de doenças no campo, além da própria situação fisiológica das plantas, o que pode diminuir tanto a quantidade de frutos quanto o rendimento dos mesmos. 
Para massa média dos frutos os valores variaram de 73,07 gramas (ECL-7) a 139,47 gramas (Rubi Gigante). Esses valores condizem com o ocorrido com o rendimento de frutos (Tabela 10). Da mesma forma, diferentes resultados foram encontrados por GRECO (2014), onde a massa média dos frutos variou de 128,75 a $226,85 \mathrm{~g}$, sendo os maiores valores registrados para as progênies Planta 7 e EC3-0.

Para a variável MASSA P, que apresentou significância na análise de variância, não foi possível observar diferenças entre as médias pelo teste Tukey $(5 \%$ de probabilidade). A massa de polpa variou de 13,97 gramas (ECL 7) a 40,76 gramas (MAR 20\#21) entre os genótipos estudados (Tabela 10). A variável MASSA P apresentou o maior valor de $\operatorname{CVg}(28,02)$ de todos as variáveis analisadas, e o valor da relação entre o $\mathrm{CVg} / \mathrm{CVe}$ de 0,82 (Tabela 10). Dados semelhantes foram observados por FREITAS et al. (2011), que desenvolveram trabalho com objetivo de caracterizar e avaliar recursos genéticos de maracujazeiro azedo (Passiflora edulis Sims) quanto às principais características de importância econômica. No trabalho desenvolvido na Bahia, verificaram coeficientes de variação genética elevados, acima de 25\% para as características estudadas (número de frutos, produtividade, massa média de frutos, massa de casca e massa de polpa). É importante salientar que os altos valores do coeficiente de variação genético devem estar associados a valores menores do coeficiente de variação ambiental para serem interessantes em programas de melhoramento genético de plantas por indicarem alto potencial de ganhos por seleção.

No que se refere à MASSA C, as progênies ECL 7 e Gigante Amarelo Pl.1 apresentaram os menores valores (58,67 gramas e 60,67 gramas, respectivamente) (Tabela 10), próximos dos valores médios observado por JUNQUEIRA et al. (2006), onde para as espécies $P$. nitida, $P$. alata e P. edulis f. flavicarpa, os valores médios para peso de casca foram de 75,39 g, 78,72 g e 63,92 g, respectivamente. O maior valor de MASSA C encontrado no presente trabalho foi de 106,67 gramas (EC3-0), sendo que o valor da média geral de massa de casca encontrado entre as progênies estudadas foi de 84,26 gramas. NEGREIROS et al. (2008) também avaliaram essa característica nos frutos de maracujá amarelo provenientes de 39 progênies de meios-irmãos e verificaram valor da média geral da massa de casca entre as progênies de 80,37 g. GRECO et al. (2014) verificaram um valor de média geral da massa de casca entre as progênies estudadas em 2010 de 104 gramas, um pouco superior ao encontrado no presente trabalho. 


\subsection{Correlação Fenotípica entre as características agronômicas, de análise física e de doenças nas 10 progênies avaliadas.}

Foram observados valores significativos dos coeficientes de correlação de Pearson das características estudadas no presente trabalho que variaram de $\mathrm{r}_{\mathrm{f}}=0,62$ à $\mathrm{r}_{\mathrm{f}}=1,00$ (Tabela 10). Segundo CARVALHO et al. (2004), a classificação de intensidade da correlação para $\mathrm{p} \leq 0,05$ é: muito forte $(\mathrm{r} \pm 0,91 \mathrm{a} \pm 1,00)$, forte $(\mathrm{r} \pm 0,71 \mathrm{a} \pm 0,9)$, média $(\mathrm{r} \pm 0,51 \mathrm{a} \pm 0,70)$ e fraca $(\mathrm{r} \pm 0,31 \mathrm{a} \pm 0,50)$. Dessa forma, nesse trabalho, a intensidade da correlação foi considerada de média à muito forte, tanto para correlações positivas quanto para negativas.

As correlações de maior magnitude e positivas $\left(\mathrm{r}_{\mathrm{f}}=1,0\right)$ ocorreram entre as características: relação entre produção total/ número total de frutos (pt/nf) e quilogramas por hectare $(\mathrm{kg} / \mathrm{ha})$; quantidade de frutos por planta $(\mathrm{F} /$ planta) e quantidade de frutos por hectare (F/ha). Considera-se 1,0 um valor de correlação perfeito, ou seja, muito forte, indicando que ao selecionar uma característica que apresenta tal valor de correlação com outra, as duas irão ter resultados semelhantes. No caso das características que demonstraram tal valor, implica que ao selecionarmos progênies que apresentam maior relação entre produção total e número total de frutos, serão selecionados aqueles que apresentaram maior valor de quilogramas por hectare. Esse resultado é interessante já que tais características podem ser mensuradas facilmente no campo experimental.

Verificou-se correlações positivas entre as características peso de fruto e número de frutos, total e em cada classificação, sendo observada correlação muito forte e positiva entre peso total de frutos e número de frutos total $\left(\mathrm{r}_{\mathrm{f}}=0,99\right)$. Tais resultados indicam que para aumentar o peso total de frutos pode-se selecionar aquelas progênies que apresentarem maior quantidade de frutos na totalidade. VILELA (2013), trabalhando com 32 progênies de maracujá azedo no Distrito Federal também observou valores de correlação fenotípica positiva entre essas características

As características de número de sementes (NSEM) e massa de polpa (M POLP) também apresentaram correlação muito forte e positiva $\left(\mathrm{r}_{f}=0,96\right)$, indicando que quanto maior o número de sementes por fruto, maior também será a massa da polpa dos frutos. Além disso, observaram-se correlações positivas e fortes entre as características de massa de fruto (M FRUTO) e massa e polpa (M POLPA), de $\mathrm{rf}=0,90$ e entre o número de sementes e a característica de rendimento (REND), com $r_{\mathrm{f}}=0,89$ (Tabela 11). Esses 
resultados são interessantes por demonstrarem que a quantidade de sementes tem estreita relação com a massa da polpa e o rendimento de polpa para suco. Segundo TEIXEIRA (1995), a quantidade de pólen depositado no estigma da flor do maracujá determina a quantidade de sementes do fruto, o tamanho do fruto, a quantidade de polpa e, consequentemente, o peso do fruto. Além disso, JUNQUEIRA et al. (2001), em documento sobre a importância da polinização natural para aumentar a produtividade do maracujazeiro, indicaram que menor número de sementes foi encontrado em frutos autopolinizados de maracujá, implicando em frutos menores e com menor conteúdo de suco. Nesse mesmo pensamento, FORTALEZA et al. (2005), afirmaram que a massa do fruto pode ser relacionada com o número de sementes viáveis, sendo que nos frutos de maracujá esse fato está relacionado com o rendimento de suco, já que é o arilo da semente que forma a polpa e cada semente é envolta por um arilo. Dessa forma, para a seleção de materiais com maior rendimento de suco, o número de sementes poderia ser uma característica facilmente avaliada e proporcionaria bons resultados.

Em conformidade com esses resultados, SANTOS et al. (2009), em trabalho desenvolvido sobre as características físicas do maracujá-azedo em função do genótipo e massa do fruto, observaram que a massa do fruto apresentou correlação significativa com massa fresca da casca $(\mathrm{rf}=0,853)$, massa fresca do suco $(\mathrm{rf}=0,889)$, massa fresca de sementes $(\mathrm{rf}=0,886)$ e número de sementes $(\mathrm{rf}=0,814)$. GRECO et al. (2014), também verificaram correlação positiva, mais de baixa intensidade $\left(\mathrm{r}_{\mathrm{f}}=0,35\right)$ entre as características de número de sementes e massa de fruto.

A característica de comprimento (COMP) também apresentou correlação forte e positiva com o diâmetro do fruto (DIAM) e com a massa do fruto $\left(\mathrm{r}_{\mathrm{f}}=0.75\right.$ e $\mathrm{r}_{\mathrm{f}}=0,86$, respectivamente). Além disso, a característica de diâmetro do fruto se correlacionou de forma positiva, forte e muito forte, com as características: rendimento, número de sementes, massa de fruto, massa de polpa e massa de casca $\left(\mathrm{r}_{\mathrm{f}}=0,72 ; 0,85 ; 0,96 ; 0,90 \mathrm{e}\right.$ 0,94, respectivamente) (Tabela 10). Esses resultados demonstram a importância da característica de diâmetro do fruto na qualidade dos frutos de maracujá azedo. Semelhante ao encontrado, GRECO et al. (2014) verificaram que houve correlação fenotípica forte e positiva entre as características, comprimento e o diâmetro dos frutos $(\mathrm{rf}=0,86)$, massa do fruto e diâmetro $(\mathrm{rf}=0,86)$. Santos et al. (2009) também observaram que o diâmetro equatorial promoveu maior influência sobre a massa fresca do fruto $(\mathrm{rf}=0,90)$. 
De acordo com os resultados obtidos por NEGREIROS (2007), ganhos indiretos no peso do fruto podem ser obtidos via resposta correlacionada por seleção do diâmetro do fruto. A seleção dos frutos com maior diâmetro equatorial possibilita a obtenção de maracujás mais pesados e com maior rendimento de polpa, uma vez que o diâmetro tem maior efeito direto sobre o peso da polpa e rendimento. O rendimento da polpa também pode ser selecionado indiretamente, com base na menor espessura da casca.

No que se refere às doenças avaliadas nesse estudo, foi possível encontrar valores do coeficiente de correlação de Pearson de $\mathrm{r}_{\mathrm{f}}=0,69$ entre as características de incidência e severidade de bacteriose, e de $\mathrm{r}_{\mathrm{f}}=0,93$ entre as características de incidência e severidade de virose. Esses resultados demonstram que a maior taxa de incidência está relacionada com a maior severidade da doença nas plantas.

Correlações fenotípicas negativas significativas, de médio a forte magnitude, também foram encontradas entre algumas características, tais como: peso de fruto $3^{\mathrm{a}} \mathrm{e}$ número de frutos $3 \mathrm{~A}$ com a característica de comprimento; diâmetro; número de sementes; massa de fruto; massa de polpa; e massa da casca (Tabela 10). Esses resultados indicam que progênies que apresentarem maiores valores de peso de frutos na classificação 3A, terão grande probabilidade de produzir frutos de menor comprimento e diâmetro, com menores quantidades de sementes, menor massa de fruto e de polpa e de casca. Além disso, a característica de número de frutos da classificação 3A também se correlacionou negativamente entre essas mesmas características (Tabela 10), indicando que a seleção de frutos dessa classificação não é interessante em um programa de melhoramento de plantas que vise maior produtividade e rendimento de frutos. 
Tabela 11. Valores do coeficiente de correlação de Pearson entre as variáveis resposta analisadas. Brasília 2005.

\begin{tabular}{|c|c|c|c|c|c|c|c|c|c|c|c|c|c|c|c|c|c|c|c|c|c|c|c|c|c|c|c|c|c|}
\hline & $\begin{array}{c}\begin{array}{c}\text { Peso } \\
1^{*}\end{array} \\
\end{array}$ & \begin{tabular}{|c} 
Peso \\
$1 \mathrm{~B}$
\end{tabular} & \begin{tabular}{|l|} 
Peso \\
1A
\end{tabular} & 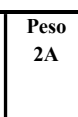 & $\begin{array}{c}\text { Peso } \\
3 \mathrm{AA}\end{array}$ & \begin{tabular}{|l|l} 
Peso \\
total
\end{tabular} & pt/nf & kg/ha & NF $1^{a}$ & NF 1B & $\begin{array}{l}\mathrm{NF} \\
{ }_{1 \mathrm{~A}}\end{array}$ & $\begin{array}{l}\mathrm{NF} \\
{ }_{2 \mathrm{~A}}\end{array}$ & $\begin{array}{l}\mathbf{N F} \\
\mathbf{3 A}\end{array}$ & $\begin{array}{c}\begin{array}{c}\text { Frutos } \\
\text { total }\end{array} \\
\text { tot }\end{array}$ & F/planta & F/ha & $\operatorname{comP}(\mathrm{mm})$ & $\operatorname{DIAM}(\mathbf{m m})$ & C/D & $\mathrm{EC}(\mathrm{mm})$ & 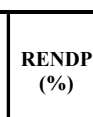 & \begin{tabular}{|l} 
N \\
SEM
\end{tabular} & $\begin{array}{c}\text { FR } \\
\text { FRUT } \\
(\mathbf{g})\end{array}$ & $\begin{array}{c}\text { M } \\
\text { POLP } \\
(\mathrm{g})\end{array}$ & $\underset{\substack{\text { CAASC } \\
(\mathbf{g})}}{\mathbf{M}}$ & \begin{tabular}{|l|} 
Bac \\
Inc
\end{tabular} & \begin{tabular}{|l|} 
Bac \\
Sev
\end{tabular} & \begin{tabular}{|l} 
Virus \\
Inc
\end{tabular} & $\begin{array}{l}\text { Virus } \\
\text { Sev }\end{array}$ \\
\hline Peso $1^{12}$ & 1,00 & $0,69 *$ & \begin{tabular}{|l|l|} 
& 0,55 \\
\end{tabular} & $\mid 0,6^{*}$ & 0,56 & $0,71^{*}$ & $\mid$\begin{tabular}{|l|l}
$\mid 0,75^{*}$ \\
\end{tabular} & $0,75^{*}$ & $0,0,3^{*}$ & $\mid 0,72^{*}$ & 0,56 & 0,60 & 0,50 & \begin{tabular}{|l|}
$\mid 0,72^{*}$ \\
\end{tabular} & $0,81^{* * *}$ & $0,81^{* * *}$ & $-0,53$ & 0,20 & $\mid-0,49$ & 0,21 & 0,06 & \begin{tabular}{|l|l|} 
& $-0,04$
\end{tabular} & $-0,30$ & $|-0,13|$ & $-0,36$ & \begin{tabular}{|l|}
0,16 \\
\end{tabular} & \begin{tabular}{|l|}
$-0,19$ \\
\end{tabular} & \begin{tabular}{|l|l|} 
& 0,27
\end{tabular} & \begin{tabular}{|l|l|} 
& 0,21 \\
\end{tabular} \\
\hline $\begin{array}{l}\text { Peso 1B } \\
\end{array}$ & & \begin{tabular}{|l|l|}
1,00 \\
\end{tabular} & $0,84^{* * *}$ & 0,58 & 0,32 & $0,89 * *$ & \begin{tabular}{|l|l|} 
& 0,62 \\
\end{tabular} & 0,62 & $\mid 0,65^{*}$ & $0,98^{* * *}$ & $0,86^{* * *}$ & 0,51 & 0,24 & $\left|0,92^{2 * *}\right|$ & $0,73^{*}$ & $\mid 0,73^{*}$ & $-0,14$ & $-0,03$ & $-0,14$ & 0,07 & 0,18 & \begin{tabular}{|l|l|} 
& 0,14
\end{tabular} & $-0,05$ & \begin{tabular}{|l|l|}
0,05 \\
\end{tabular} & \begin{tabular}{|l|}
0,11 \\
\end{tabular} & $0, \overline{0} \mid$ & $|-0,16|$ & \begin{tabular}{|l|l|} 
& 0,02 \\
\end{tabular} & \begin{tabular}{|l|l|} 
& $-0,06$ \\
\end{tabular} \\
\hline Peso $1^{12}$ & & & \begin{tabular}{|l|}
1,00 \\
\end{tabular} & $0,83^{* * *}$ & 0,43 & $0,98^{* *}$ & \begin{tabular}{|l|l|} 
& $0,76^{*}$
\end{tabular} & $0,76^{*}$ & $\mid 0,64^{*}$ & $0,8^{* * *}$ & $0,99 * *$ & $0,81^{* * *} \mid$ & 0,38 & $|0,95 * *|$ & $0,80^{* * *}$ & $0,80^{* * *}$ & $-0,41$ & $-0,28$ & $\mid-0,17$ & 0,00 & $-0,10$ & \begin{tabular}{|l|l|} 
& $-0,15$
\end{tabular} & $-0,35$ & 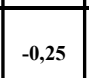 & $-0,37$ & 0 & \begin{tabular}{|l|} 
\\
\end{tabular} & \begin{tabular}{|l|l|} 
& $-0,05$
\end{tabular} & $-0,26$ \\
\hline $\begin{array}{l}\text { Peso } 2^{n} \\
\text { nat }\end{array}$ & & & & 1,00 & 0,44 & $0,86^{* * *}$ & $0,85^{* * *}$ & $0,85^{* * *}$ & $0,82^{* * *}$ & \begin{tabular}{|l|l|} 
& 0,61
\end{tabular} & $0,82^{2 * *}$ & $0,98^{* *} \mid$ & 0,40 & $0,83^{* * *} \mid$ & $\mathbf{0 , 8 6 ^ { * * * }}$ & $0,86^{* * *}$ & $-0,60$ & $-0,32$ & $-0,41$ & $-0,05$ & $-0,27$ & \begin{tabular}{|l|l|} 
& $-0,25$
\end{tabular} & $-0,46$ & \begin{tabular}{|l|}
$-0,40$ \\
\end{tabular} & $-0,45$ & \begin{tabular}{|l|} 
\\
\end{tabular} & $\mid-0,36$ & 0,25 & \begin{tabular}{|l|l|} 
& 0,02 \\
\end{tabular} \\
\hline Peso $3^{\mathrm{a}}$ & & & & & 1,00 & 0,51 & \begin{tabular}{|l|l|} 
& 0,61 \\
\end{tabular} & \begin{tabular}{|l|}
0,61 \\
\end{tabular} & 0,46 & \begin{tabular}{|l|}
0,28 \\
\end{tabular} & \begin{tabular}{|l|l|} 
& 0,45
\end{tabular} & 0,49 & $0,99 * *$ & 0,46 & 0,60 & \begin{tabular}{|l|l|} 
& 0,60
\end{tabular} & $-0,71^{*}$ & $-0,78^{* *}$ & \begin{tabular}{|l|l|}
0,09 \\
\end{tabular} & 0,06 & $-0,38$ & \begin{tabular}{|l|} 
\\
\end{tabular} & $-0,82^{* * *}$ & $-0,67^{*} \mid$ & $-0,81^{* * *}$ & \begin{tabular}{|l|}
0,03 \\
\end{tabular} & \begin{tabular}{|l|}
0,02 \\
\end{tabular} & 0,14 & 0,09 \\
\hline Peso total & & & & & & 1,00 & $0,83^{* *}$ & $0,83^{* *}$ & $\mid 0,76^{*}$ & $0,86^{* *}$ & $0,98^{* *}$ & $0,8^{* * *}$ & 0,45 & $\mid 0,99 * *$ & $0,88^{* *}$ & $0,88^{* *}$ & $-0,46$ & $-0,30$ & $-0,22$ & 0,03 & $-0,09$ & $\mid-0,14$ & $-0,37$ & \begin{tabular}{|l|}
$-0,26$ \\
\end{tabular} & $-0,40$ & 0,26 & $\mid-0,24$ & 0,06 & $-0,12$ \\
\hline $\mathrm{p}^{\mathrm{p} t \mathrm{nf}}$ & & & & & & & \begin{tabular}{|l|l|} 
& 1,00
\end{tabular} & $1,00^{* *}$ & $0,85^{* * *}$ & \begin{tabular}{|l|l|} 
& 0,58
\end{tabular} & $0,75^{*}$ & $0, \mathbf{8 1} 1^{* *}$ & 0,56 & $0,77^{7 * *}$ & $0,99^{* * *}$ & $0,99 * *$ & $-0,67^{*}$ & $-0,56$ & $|-0,20|$ & 0,15 & $-0,46$ & $-0,46$ & $-0,63^{*}$ & \begin{tabular}{|l|}
$-0,57$ \\
\end{tabular} & $-0,61$ & \begin{tabular}{|l|}
0,08 \\
\end{tabular} & $\mid-0,04$ & 0,13 & $-0,09$ \\
\hline $\mathrm{kg} / \mathrm{ha}$ & & & & & & & & 1,00 & $0,85^{* *}$ & \begin{tabular}{|l|l|} 
& 0,58
\end{tabular} & $0,75^{*}$ & $0,81^{* * *}$ & 0,56 & $0,77^{* * *}$ & $0,9^{* * *}$ & $0,99^{* * *}$ & $-0,67^{*}$ & $-0,56$ & $-0,20$ & 0,15 & $-0,46$ & $-0,46$ & $-0,63^{*}$ & \begin{tabular}{|l|l|}
$-0,57$ \\
\end{tabular} & $-0,61$ & 0 & $-0,04$ & 0,13 & $-0,09$ \\
\hline $\mathrm{NF} 1^{\mathrm{a}}$ & & & & & & & & & \begin{tabular}{|l|l|} 
& 1,00
\end{tabular} & $\mid 0,67^{*}$ & \begin{tabular}{|l|l|} 
& $0,64^{*}$
\end{tabular} & \begin{tabular}{|l|l|}
$0,75^{*}$ \\
\end{tabular} & 0,41 & \begin{tabular}{|l|l|}
$0,76^{*}$ \\
\end{tabular} & $0,87^{* * *}$ & $0,8^{* * *}$ & $-0,65^{*}$ & $-0,22$ & $|-0,62|$ & 0,25 & $-0,02$ & $-0,08$ & $-0,37$ & \begin{tabular}{|l|}
$-0,20$ \\
\end{tabular} & \begin{tabular}{|l|} 
\\
\end{tabular} & \begin{tabular}{|l|l|}
0,02 \\
\end{tabular} & $|-0,16|$ & 0,24 & 0,09 \\
\hline $\mathrm{NF} 1 \mathrm{~B}$ & & & & & & & & & & \begin{tabular}{|l|}
1,00 \\
\end{tabular} & $0,83^{3 * *}$ & 0,54 & 0,21 & $0,92^{2 * *}$ & $0,70^{*}$ & $\mid 0,70^{*}$ & $-0,14$ & 0,02 & $\mid-0,22$ & 0,00 & 0,25 & 0,24 & 0,00 & \begin{tabular}{|l|l|} 
& 0,11
\end{tabular} & $-0,08$ & \begin{tabular}{|c|}
0,05 \\
\end{tabular} & $|-0,31|$ & 0,19 & \begin{tabular}{|l|l} 
& 0,12 \\
\end{tabular} \\
\hline $\mathrm{NF} 1^{\mathrm{a}}$ & & & & & & & & & & & 1,00 & $0,80^{* * *}$ & 0,40 & $0,97 *$ & $0,81^{* * *}$ & $0,81^{* * *}$ & $-0,40$ & $-0,29$ & \begin{tabular}{|l|} 
\\
\end{tabular} & $-0,02$ & $-0,08$ & $-0,12$ & $-0,35$ & 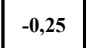 & \begin{tabular}{|l|}
$-0,37$ \\
\end{tabular} & $0-\overline{36}$ & \begin{tabular}{|l|} 
\\
\end{tabular} & 0,01 & \begin{tabular}{|l|l|} 
& $-0,18$ \\
\end{tabular} \\
\hline $\mathrm{NF} 2^{\mathrm{n}}$ & & & & & & & & & & & & 1,00 & 0,48 & $0,79^{* * *}$ & $0,81^{* * *}$ & $0,81^{* * *}$ & $-0,65^{*}$ & $-0,40$ & $|-0,38|$ & $-0,13$ & $-0,30$ & $-0,31$ & $-0,53$ & $-0,45$ & $-0,53$ & \begin{tabular}{|c|}
0,48 \\
\end{tabular} & $-0,43$ & 0,26 & \begin{tabular}{|l|l} 
& 0,01 \\
\end{tabular} \\
\hline $\mathrm{NF}^{33^{\mathrm{a}}}$ & & & & & & & & & & & & & 1,00 & 0,40 & 0,54 & 0,54 & $-0,72^{*}$ & $-0,79 * *$ & \begin{tabular}{|l|} 
\\
\end{tabular} & 0,04 & $-0,38$ & $-0,63$ & $-0,83^{* * *}$ & 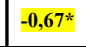 & $-0,82^{* * *}$ & 0.04 & $-0,02$ & 0,14 & \begin{tabular}{|l|l|} 
& 0,08 \\
\end{tabular} \\
\hline Frutos total & & & & & & & & & & & & & & 1,00 & $0,85^{* * *}$ & $0,85^{* *}$ & $-0,40$ & $-0,22$ & $|-0,25|$ & 0,00 & 0,02 & $-0,02$ & $-0,29$ & \begin{tabular}{|l|}
$-0,16$ \\
\end{tabular} & \begin{tabular}{|l|} 
\\
\end{tabular} & 0.25 & $-0,31$ & 0,15 & $-0,02$ \\
\hline $\mathbf{F} /$ planta & & & & & & & & & & & & & & & 1,00 & $1,00^{* * *}$ & $-0,62$ & $-0,50$ & $|-0,21|$ & 0,11 & $-0,36$ & $-0,35$ & $-0,56$ & $-0,48$ & $-0,55$ & $\begin{array}{l}0.08 \\
0,0\end{array}$ & $-0,13$ & 0,21 & \begin{tabular}{|l|l} 
& 0,00 \\
\end{tabular} \\
\hline F/ha & & & & & & & & & & & & & & & & \begin{tabular}{|l|}
1,00 \\
\end{tabular} & $-0,62$ & $-0,50$ & \begin{tabular}{|l|}
$-0,21$ \\
\end{tabular} & 0,11 & $-0,36$ & $-0,35$ & $-0,56$ & $-0,48$ & $-0,55$ & 0. & $-0,13$ & 0,21 & \begin{tabular}{|l|l|}
0,00 \\
\end{tabular} \\
\hline $\operatorname{COMP}(\mathrm{mm})$ & & & & & & & & & & & & & & & & & 1,00 & $0,75^{*}$ & \begin{tabular}{|l|}
0,41 \\
\end{tabular} & $-0,06$ & 0,31 & 0,53 & $0,86^{* * *}$ & 0,61 & $0,92^{* \star}$ & \begin{tabular}{|l|l|}
0,27 \\
\end{tabular} & 0,09 & $-0,24$ & \begin{tabular}{|l|l|}
$-0,02$ \\
\end{tabular} \\
\hline
\end{tabular}




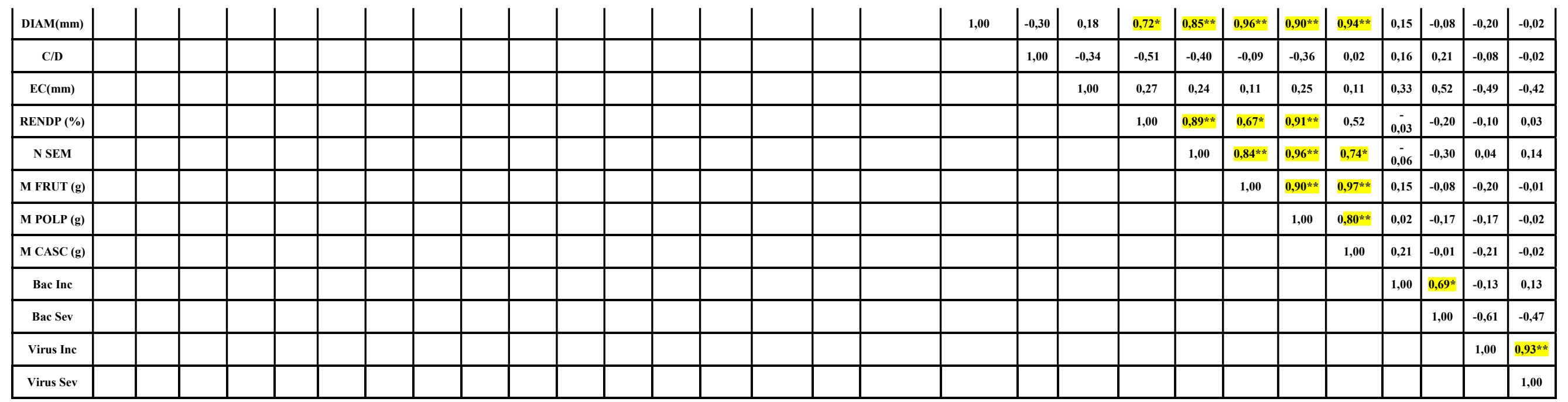

Peso $1^{\mathrm{a}}$ : produtividade total estimada para frutos de primeira $\mathrm{kg} / \mathrm{ha}$, Peso 1B: produtividade total estimada pra frutos de $1 \mathrm{~B}$ em $\mathrm{kg} / \mathrm{ha}$, Peso $1 \mathrm{~A}$ : produtividade total estimada para frutos $1 \mathrm{~A} \mathrm{em} \mathrm{kg/ha,} \mathrm{Peso} \mathrm{2A:} \mathrm{produtividade} \mathrm{total} \mathrm{estimada} \mathrm{para} \mathrm{frutos} \mathrm{2A} \mathrm{em} \mathrm{kg/ha,} \mathrm{Peso} \mathrm{3A:} \mathrm{produtividade} \mathrm{total} \mathrm{estimada} \mathrm{para} \mathrm{frutos} 3 \mathrm{~A}$ em kg/ha, Peso total: produtividade total estimada, $\mathrm{pt} / \mathrm{nf}$ : peso total/ $\mathrm{n}^{\mathrm{o}}$ de frutos, $\mathrm{kg} / \mathrm{ha}$ : peso por ha , NF 1 $1^{\mathrm{a}}$ : número total de frutos de primeira/ha, NF 1B: número total de frutos 1B/ha, NF 1A: número total de frutos 1A/ha, NF 2A: número total de frutos 2A/ha, NF 3A: número total de frutos 3A/ha, F/planta: fruto/planta, F/ha: fruto/ha, COMP (mm): comprimento médio do fruto,

DIAM(mm): diâmetro médio do fruto, C/D: relação comprimento e diâmetro dos frutos, $\mathrm{EC}(\mathrm{mm})$ : espessura média da casca dos frutos, RENDP (\%): rendimento de polpa, expresso em porcentagem, N SEM: número de sementes por fruto, M FRUT (g): massa do fruto, M POLP (g): massa de polpa, M CASC (g): massa de casca, Bac Inc: Incidência da bacteriose, Bac Sev: Severidade da bacteriose, Vírus Inc: Incidência de vírus, Vírus Sev: Severidade de vírus. (**) - valores com dois asteriscos são significativos a 1\% de probabilidade pelo teste $(*)$ - valores com asterisco são significativos a $5 \%$ de probabilidade pelo teste $\mathrm{t}$. 


\section{CONCLUSÕES}

As progênies que se destacaram com maior produtividade total estimada e número de frutos foram a ECL-7, Gigante Amarelo pl. 1 e MAR 20\#41.

Para fins industriais, a maior produtividade foi verificada nas progênies ECL-7 e MSCA e consumo in natura as progênies com melhor desempenho foram, Gigante Amarelo pl. 1 e MAR 20\#41.

As progênies com menor incidência e severidade da virose do endurecimento dos frutos foram MAR 20\#21 e Gigante amarelo pl. 1, respectivamente. Todos os materiais analisados foram classificados como moderadamente suscetíveis.

Para bacteriose, as progênies Rosa Intenso e MSCA obtiveram as menores incidência e severidade, respectivamente. MSCA, Rosa Intenso, MAR 20\#41, Rubi Gigante e EC-RAM 3 foram classificadas como resistentes e as demais progênies, como moderadamente suscetíveis.

A progênie EC3-0 apresentou o maior COMP, diferindo de ECL-7, que apresentou o menor valor para essa variável. Gigante Amarelo pl. 1 e MAR 20\#41 apresentaram, respectivamente, os maiores e os menores valores de DIAM e C/D. Os valores de REND variaram de 17,86\% (ECL-7) a 30,90\% (MAR 20\#21). Rubi Gigante, MAR 20\#21 e EC3-0 apresentaram, respectivamente, os maiores valores para MASSA F, MASSA P e MASSA C, enquanto ECL-7 foi a progênie com os menores valores para essas variáveis.

Observaram-se correlações de magnitude média e positiva entre a incidência e a severidade de bacteriose, e forte e positiva entre a incidência e a severidade da virose. Foram observadas correlações de magnitudes fortes e positivas entre as características: produção total/número total de frutos $(\mathrm{pt} / \mathrm{nf})$ e quilogramas por hectare $(\mathrm{kg} / \mathrm{ha})$; quantidade de frutos por planta (F/planta) e quantidade de frutos por hectare $(\mathrm{F} / \mathrm{ha})$. 


\section{REFERÊNCIAS BIBLIOGRÁFICAS}

ALVES, J. C. S. Estimativa de parâmetros genéticos para caracteres de semente e de planta em populações de cenoura (Daucus carota L.) derivadas da cultivar Brasília. Brasília: UNB. 67p. (Dissertação de Mestrado), 2004.

CASTRO, Ana Paula Gomes de. Desempenho agronômico, diversidade genética e avaliação de doenças em progênies de maracujazeiro-azedo. 2015. 204 f., il. Tese (Doutorado em Agronomia) —Universidade de Brasília, Brasília, 2015.

DURIGAN, J. F.; SIGRIST, J. M. M.; ALVES, R. E.; FILGUEIRAS, H. A. C.; VIEIRA, G. Qualidade e tecnologia pós-colheita do maracujá. In: LIMA, A. de A.; CUNHA, M.A. P. (Org.). Maracujá: produção e qualidade na passicultura. Cruz das Almas: Embrapa Mandioca e Fruticultura, 2004. p. 283-303.

FALEIRO, F. G.; JUNQUEIRA, N. T. V.; FÁVERO, A. P.; LOPES, M. A. Prémelhoramento de plantas: experiências de sucesso. In: FALEIRO, F. G.; NETO, A. L. F.; JÚNIOR, W. Q. R. Pré-melhoramento, melhoramento e pós melhoramento: estratégias e desafios. Planaltina, DF: Embrapa Cerrados; Brasília DF: Embrapa Informação Tecnológica, 2008.

FALEIRO, F.G.; JUNQUEIRA, N.T.V. Recursos genéticos: conservação, caracterização e uso. In: FALEIRO, F.G.; ANDRADE, S.R.M.; REIS JÚNIOR, F.B. Biotecnologia: estado da arte e aplicações na agropecuária. Planaltina,DF: Embrapa Cerrados, 2011a. p. 513-551.

FARIAS, M.A.A.; FARIA, G.A.; CUNHA, M.A.P. DA; PEIXOTO, C.P.; SOUSA, J.S. Caracterização física e química de frutos de maracujá-amarelo de ciclos de seleção massal estratificada e de populações regionais. Magistra, Cruz das Almas, v. 17, n. 2, p. 83-87, 2005 .

FERRAZ, J. V.; LOT, L. Fruta para consumo in natura tem boas perspectivas de renda. In: AGRIANUAL 2007: anuário estatístico da agricultura brasileira. São Paulo: FNP, 2007. p.387-394.

FORTALEZA, J. M.; PEIXOTO, J. R.; JUNQUEIRA, N. T. V.; OLIVEIRA, A. T.; RANGEL, L. E. P. Características físicas e químicas em nove genótipos de maracujáazedo cultivado sob três níveis de adubação potássica. Revista Brasileira de Fruticultura, Jaboticabal, v. 27, n. 1, p. 124-127, 2005.

FREITAS, Juan Paulo Xavier de et al. Avaliação de recursos genéticos de maracujazeiro-amarelo. Pesq. agropec. bras., Brasília, v. 46, n. 9, p. 1013-1020, Sept. 2011. Disponível em: <http://www.scielo.br/scielo.php?script=sci_arttext\&pid=S0100204X2011000900007\&lng=en\&nrm=iso>. Acesso em: 20 Feb. 2016. http://dx.doi.org/10.1590/S0100-204X2011000900007. 
GONÇALVES, G.M.; VIANA, A.P.; BEZERRA NETO, F.V.; PEREIRA, M.G.; PEREIRA, T.N.S. Seleção e herdabilidade na predição de ganhos genéticos em maracujáamarelo. Pesquisa Agropecuária Brasileira, v.42, p.193-198, 2007.

GONÇALVES, I.M.P. Produtividade e reação de progênies de maracujazeiro azedo a doenças em campo e casa de vegetação. Brasília: Faculdade de Agronomia e Medicina Veterinária, Universidade de Brasília-Brasília, 2011. p.121. Dissertação de Mestrado.

GRECO, S. M. L., PEIXOTO, J. R., \& FERREIRA, L. M. Avaliação física, físicoquímica e estimativas de parâmetros genéticos de 32 genótipos de maracujazeiro-azedo cultivados no Distrito Federal $=$ Physical assessment, and physical chemistry and estimates of genetic parameters 32 genotypes passionfruit... Bioscience Journal, 30(3). 2014.

IBGE - INSTITUTO BRASILEIRO DE GEOGRARIA E ESTATÍSTICA. Maracujá: área plantada e quantidade produzida. Brasília-DF. Produção Agrícola Municipal em 2009. 2012. Disponível em: http://www.sidra.ibge.gov.br/bda/tabela/protabl. Acesso em: dezembro de 2015.

JUNQUEIRA, N. T. V., VERAS, M. C. M., DO NASCIMENTO, A. C., DA COSTA CHAVES, R., MATOS, A. P., \& JUNQUEIRA, K. P. A importância da polinização manual para aumentar a produtividade do maracujazeiro. Embrapa Cerrados. 2001.

JUNQUEIRA, N.T.V.; ANJOS, J.R.N.; JUNQUEIRA, L.P; SHARMA, R.D. Doenças do maracujá-doce. In: MANICA, I.; BRANCHER, A.; SANZONOWICZ, C.; ICUMA, I.M.; AGUIAR, J.L.P.; AZEVEDO, J.A.; VASCONCELLOS, M.A.S.; JUNQUEIRA, N.T.V. Maracujá-doce: tecnologia de produção e pós-colheita. Porto Alegre, RS: ed. Cinco Continentes, 2004. p. 113-144

JUNQUEIRA, N.T.V.; ANJOS, J.R.N.; SILVA, A.P.O.; CHAVES, R.C.; GOMES, A.C. Reação às doenças e produtividade de onze cultivares de maracujá-azedo cultivadas sem agrotóxicos. Pesquisa Agropecuária Brasileira, v. 38, n. 8 p. 10051010, 2003.

KOSOSKI, R. M. Diversidade genética e reação de genótipos de maracujazeiro a septoriose, verrugose e mancha oleosa em casa de vegetação. Brasília: Faculdade de Agronomia e Medicina Veterinária, Universidade de Brasília, 2014, 146 p. Tese de Doutorado.

MANICA, I. Botânica e variedades. In: MANICA, I. (Ed.). Fruticultura tropical: maracujá. São Paulo: Agronômica Ceres, 1981. 160p.

MELETTI, L.M.M.; SOARES-SCOTT, M.D.; BERNACCI, L.C.; PASSOS, I.R.S. Melhoramento genético do maracujá: passado e futuro. In: Faleiro, F.G.; Junqueira, N.T.V.; Braga, M.F. (Eds.) Maracujá: germoplasma e melhoramento genético. Planaltina,DF: Embrapa Cerrados, 2005. p. 55-78.

MELO, K. T. Comportamento de seis cultivares de maracujazeiro- amarelo (Passiflora edulis Sims f. flavicarpa Deg.) em Vargem Bonita, no Distrito Federal. 
1999. 75f. Dissertação (Mestrado em Agronomia) - Faculdade de Agronomia e Medicina Veterinária, Universidade de Brasília, Brasília, 1999.

MOREIRA, H. S. M. Produtividade, reação a doenças e estimativas de parâmetros genéticos em progênies de maracujazeiro-azedo cultivadas no Distrito Federal. Brasília: Faculdade de Agronomia e Medicina Veterinária, Universidade de BrasíliaBrasília, 2011; 106p. Dissertação de Mestrado.

NEGREIROS, J. D. S., ALVARES, V. D. S., BRUCKNER, C. H., MORGADO, M. A. D., \& CRUZ, C. D. Relação entre características físicas e o rendimento de polpa de maracujá-amarelo. Revista Brasileira de Fruticultura, 29(3), 546-549. 2007.

NEGREIROS, J. R. D. S., ARAÚJO NETO, S. E. D., ÁlVARES, V. D. S., LiMA, V. A. D., \& OLIVEIRA, T. K. D. Caracterização de frutos de progênies de meios-irmãos de maracujazeiro-amarelo em Rio Branco-Acre. Revista Brasileira de Fruticultura, 30(2), 431-437. 2008.

OLIVEIRA, J.C. de; NAKAMURA, K.; MAURO, A. O.; CENTURION, M.A.P. da C. Aspectos gerais do melhoramento do maracujazeiro. In: São José, A.R. Maracujá, produção e mercado. Vitória da Conquista: DFZ-UESB, 1994. P. 27-37.

RANGEL, L. E. P. Desempenho agronômico de nove genótipos de maracujazeiro amarelo cultivados sob três níveis de adubação potássico no Distrito Federal. Brasília, Universidade de Brasília, 2002. 45p. Dissertação de Mestrado.

REVISTA CAMPO E NEGÓCIO. Avanços do cultivo do maracujá no Brasil. Disponível em: $<$ http://www.revistacampoenegocios.com.br/avancos-no-cultivo-de-maracujano-brasil/> Acesso: Novembro de 2015.

ROCHA, M. R. D. Estratégias de seleção no melhoramento genético do maracujazeiro azedo. Rio Parnaíba, MG. Dissertação (Mestrado em agronomia) Universidade Federal de Viçosa. 2014.

RUGGIERO, C. Situação da cultura do maracujazeiro no Brasil. Informe Agropecuário, v.21, n.206, p 5-9, 2000.

SANTOS, Carlos Eduardo Magalhães dos et al . Características físicas do maracujá-azedo em função do genótipo e massa do fruto. Rev. Bras. Frutic., Jaboticabal, v. 31, n. 4, p. 1102-1119, Dec. 2009.

SOUSA, M. A. F. Avaliação da produtividade, incidência e severidade de doenças em frutos de 17 genótipos de maracujazeiro-amarelo, cultivados no Distrito Federal. Brasília, Faculdade de Agronomia e Medicina Veterinária, Universidade de Brasília; 2005, 120p. Dissertação de Mestrado.

TEIXEIRA, C.G. 1995. Cultura. In: SÃO PAULO. Instituto de Tecnologia de Alimentos. Maracujá: cultura, materia-prima, processamento e aspectos econômicos. Campinas. cap.1, p.1-142.

VIANA, C.A. dos S. Resistência de genótipos de maracujá-azedo à bacteriose (Xanthomonas axonopodis pv. passiflorae) e à virose do endurecimento do fruto 
(Cowpea aphid-borne mosaic virus). 2007. 210 f. Dissertação (Mestrado em Fitopatologia). Universidade de Brasília, Brasília, 2007.

VILELA, M.S. Diversidade genética, produtividade e reação de progênies de maracujazeiro à doenças sob condições de campo. Faculdade de Agronomia e Medicina Veterinária, Universidade de Brasília-Brasília, 2013; 183 p. Tese de Doutorado. 


\section{ANEXOS}

Anexo 1. Curvas de regressão dos dados coletados de Severidade da virose do endurecimento dos frutos (Cowpea aphid-borne mosaic virus) dos ensaios realizados em casa de vegetação da Estação Experimental de Biologia da Universidade de Brasília UnB, no período de maio a julho de 2015.

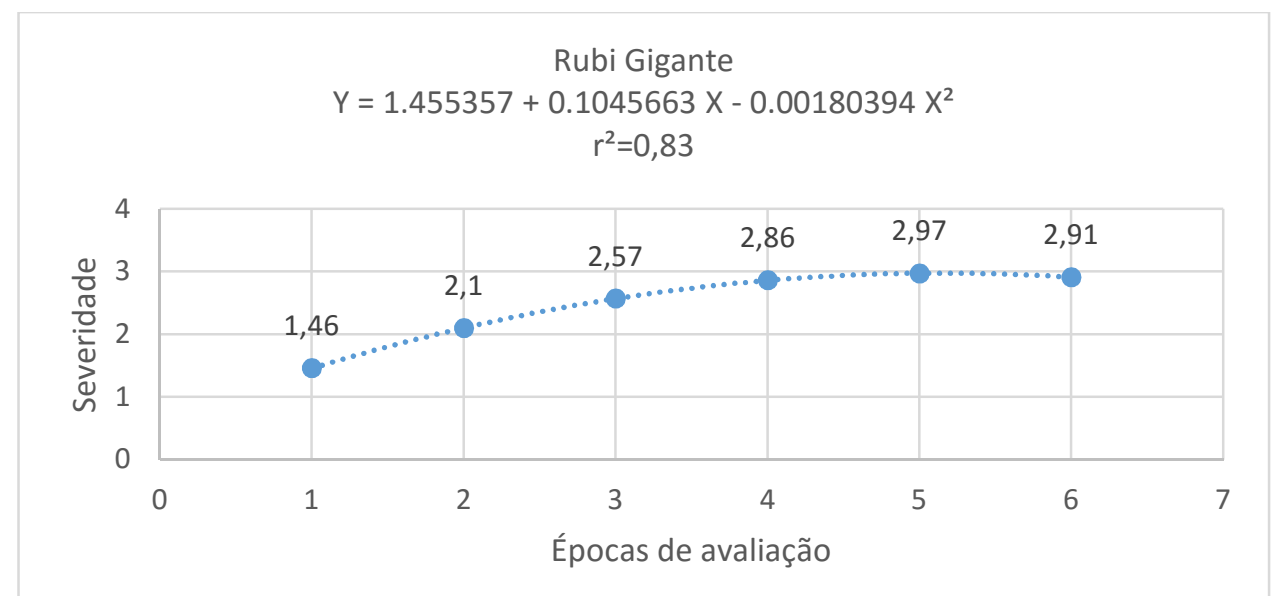

Figura 2.11 - Severidade da virose do endurecimento dos frutos (Cowpea aphid-borne mosaic virus) na progênie Rubi Gigante de maracujazeiro azedo (Passiflora edulis Sims), em 6 avaliações semanais. As curvas referem-se aos valores estimados e os pontos aos valores observados. Brasília-UnB, 2015.

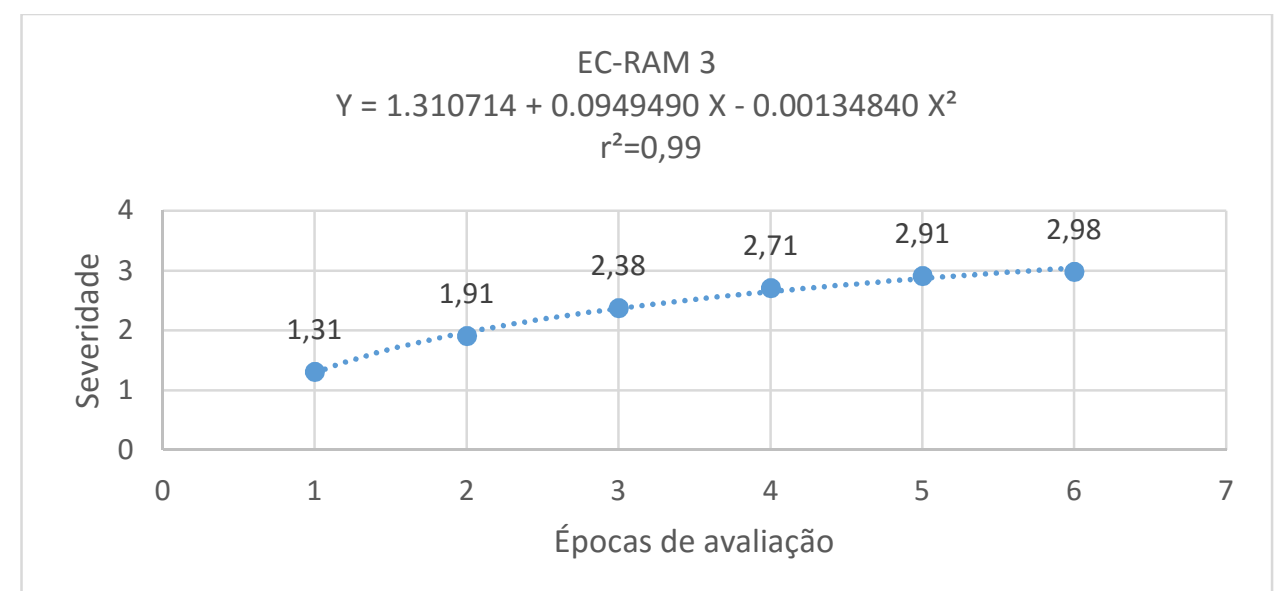

Figura 2.12 - Severidade da virose do endurecimento dos frutos (Cowpea aphid-borne mosaic virus) na progênie EC-RAM 3 de maracujazeiro azedo (Passiflora edulis Sims), em 6 avaliações semanais. As curvas referem-se aos valores estimados e os pontos aos valores observados. Brasília-UnB, 2015. 


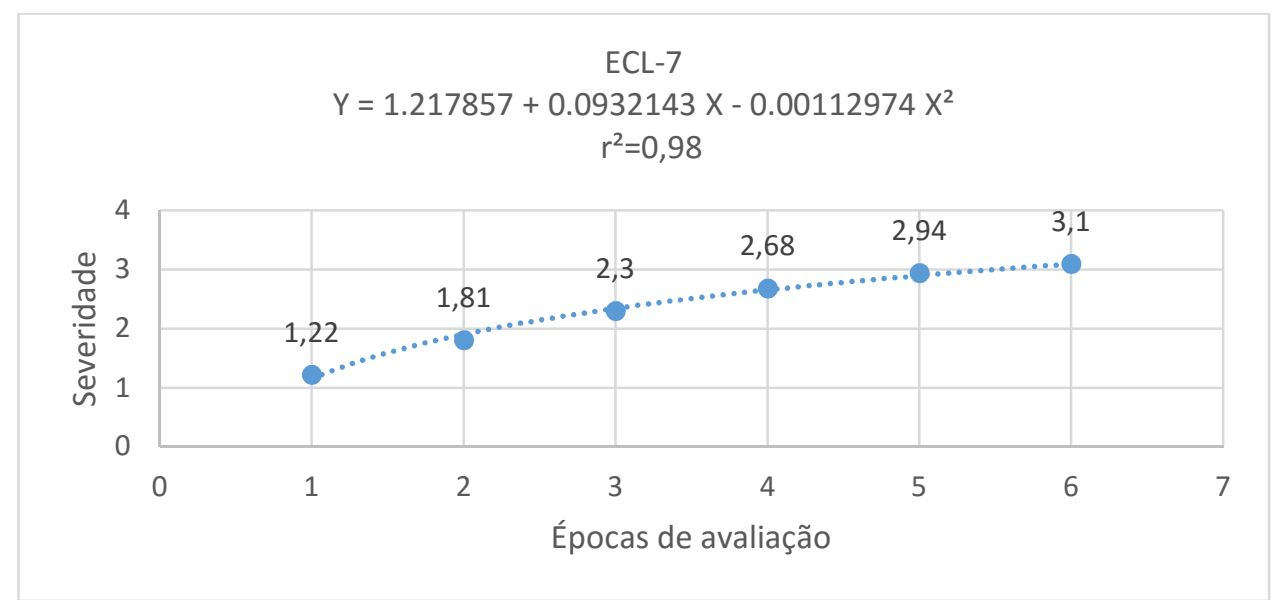

Figura 2.13 - Severidade da virose do endurecimento dos frutos (Cowpea aphid-borne mosaic virus) na progênie ECL-7 de maracujazeiro azedo (Passiflora edulis Sims), em 6 avaliações semanais. As curvas referem-se aos valores estimados e os pontos aos valores observados. Brasília-UnB, 2015.

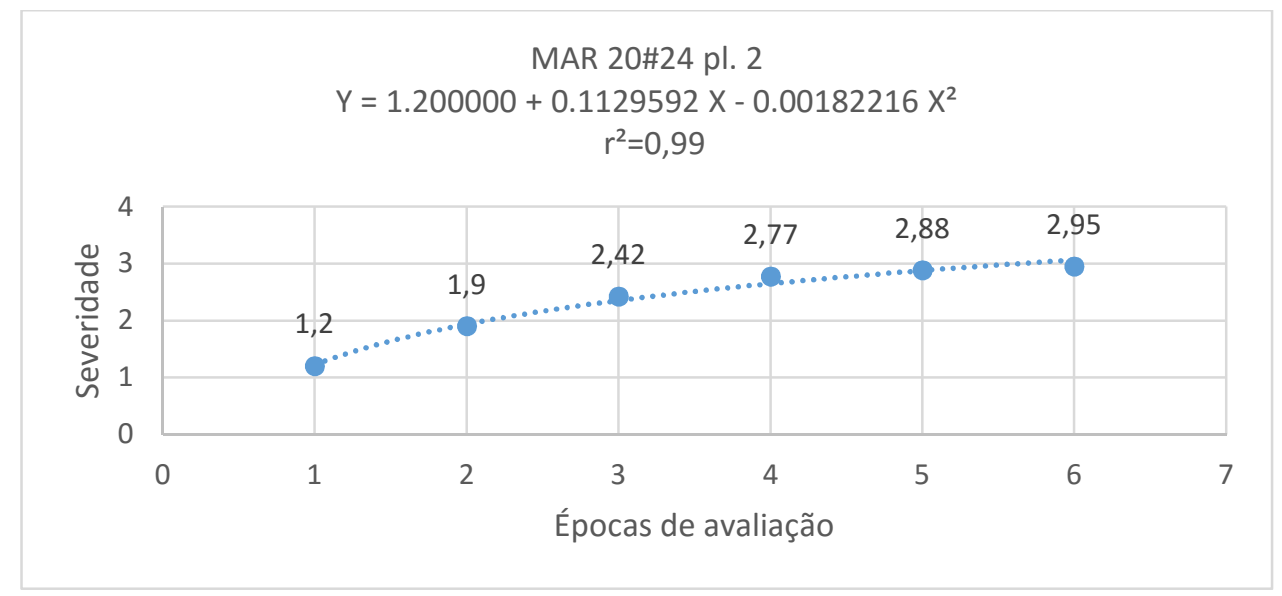

Figura 2.14 - Severidade da virose do endurecimento dos frutos (Cowpea aphid-borne mosaic virus) na progênie MAR 20\#24 pl. 2 de maracujazeiro azedo (Passiflora edulis Sims), em 6 avaliações semanais. As curvas referem-se aos valores estimados e os pontos aos valores observados. Brasília-UnB, 2015.

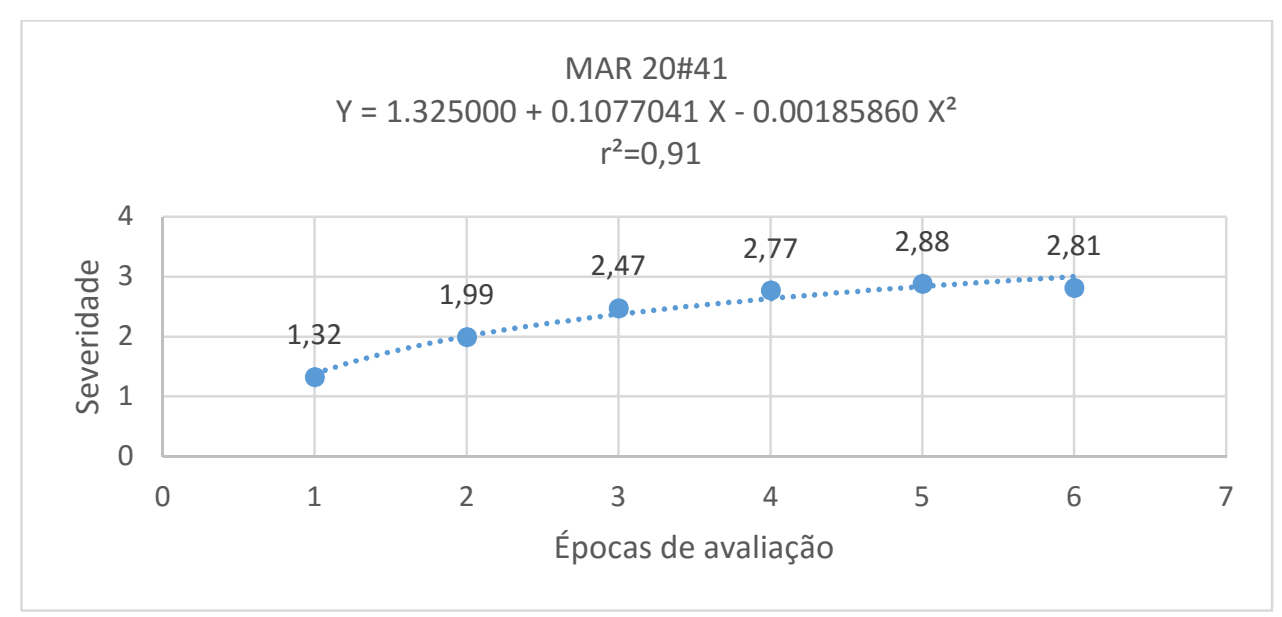

Figura 2.15 - Severidade da virose do endurecimento dos frutos (Cowpea aphid-borne mosaic virus) na progênie MAR 20\#41 de maracujazeiro azedo (Passiflora edulis Sims), em 6 avaliações semanais. As curvas referem-se aos valores estimados e os pontos aos valores observados. Brasília-UnB, 2015. 


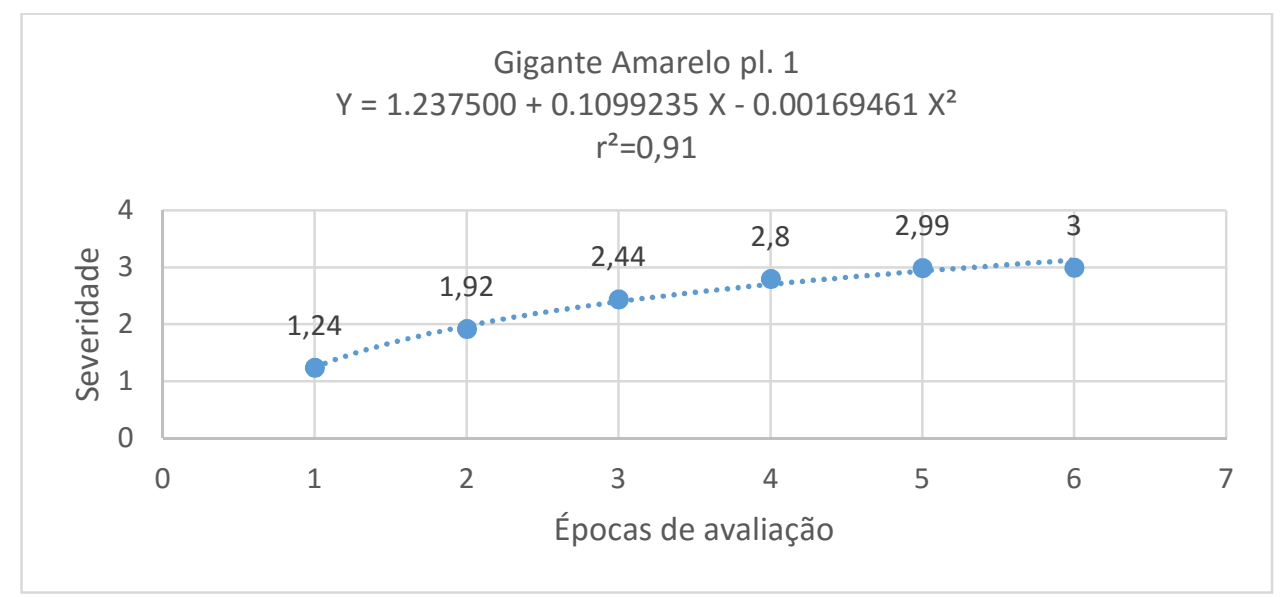

Figura 2.16 - Severidade da virose do endurecimento dos frutos (Cowpea aphid-borne mosaic virus) na progênie Gigante Amarelo pl. 1 de maracujazeiro azedo (Passiflora edulis Sims), em 6 avaliações semanais. As curvas referem-se aos valores estimados e os pontos aos valores observados. Brasília-UnB, 2015.

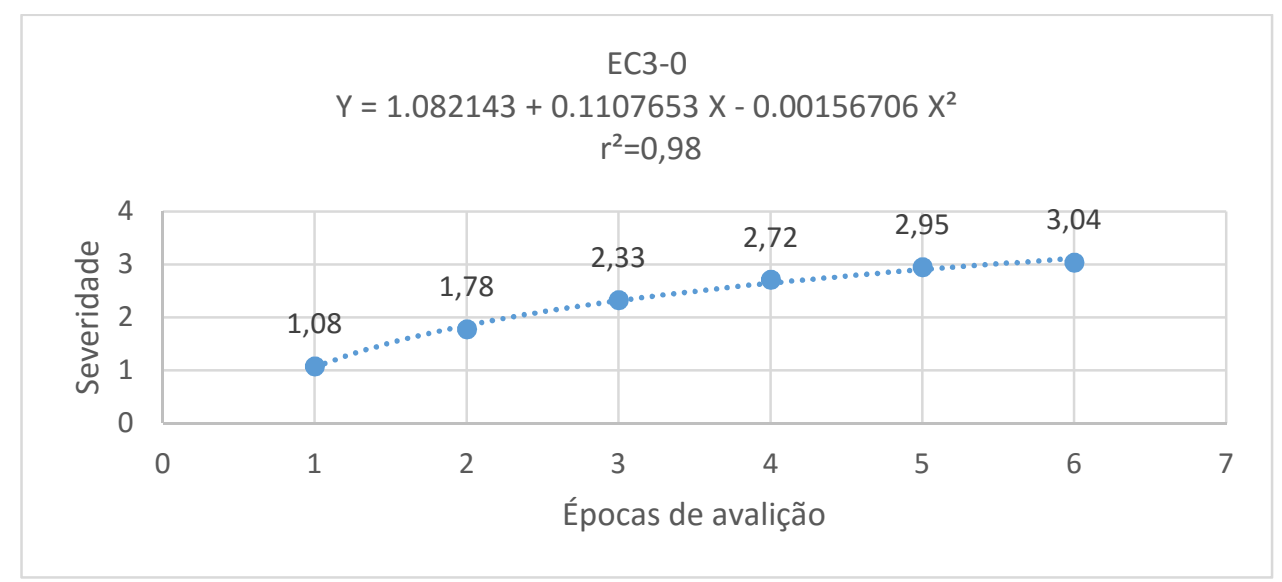

Figura 2.17 - Severidade da virose do endurecimento dos frutos (Cowpea aphid-borne mosaic virus) na progênie EC3-0 de maracujazeiro azedo (Passiflora edulis Sims), em 6 avaliações semanais. As curvas referem-se aos valores estimados e os pontos aos valores observados. Brasília-UnB, 2015.

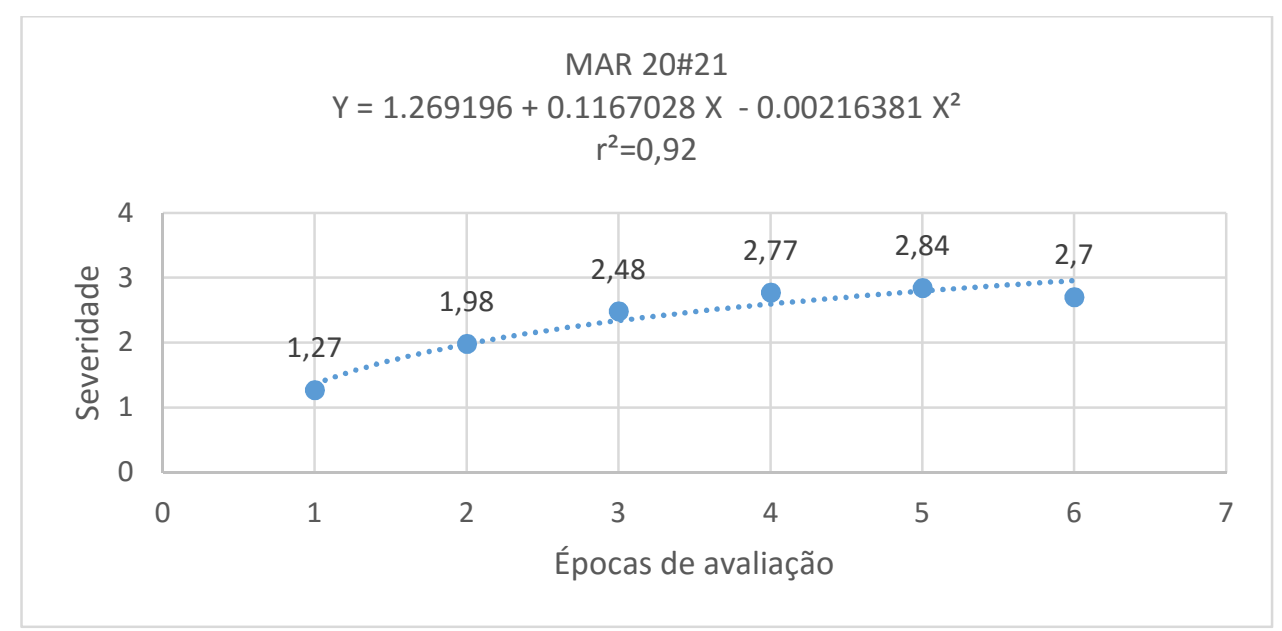

Figura 2.18 - Severidade da virose do endurecimento dos frutos (Cowpea aphid-borne mosaic virus) na progênie MAR 20\#21 de maracujazeiro azedo (Passiflora edulis Sims), em 6 avaliações semanais. As curvas referem-se aos valores estimados e os pontos aos valores observados. Brasília-UnB, 2015. 


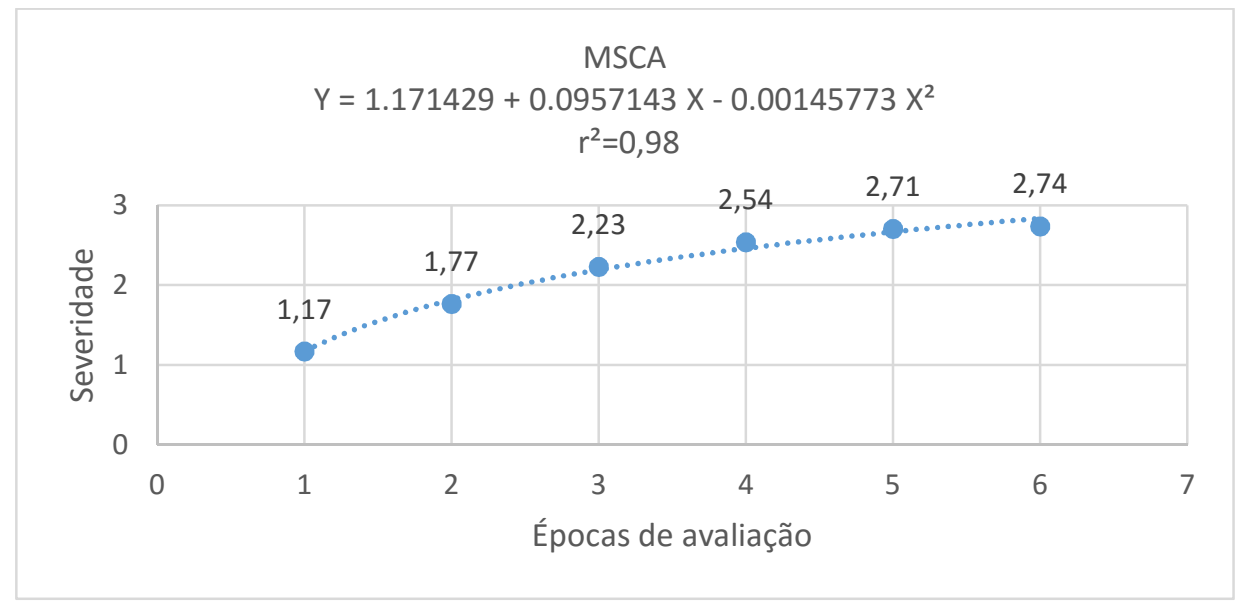

Figura 2.19 - Severidade da virose do endurecimento dos frutos (Cowpea aphid-borne mosaic virus) na progênie MSCA de maracujazeiro azedo (Passiflora edulis Sims), em 6 avaliações semanais. As curvas referem-se aos valores estimados e os pontos aos valores observados. Brasília-UnB, 2015.

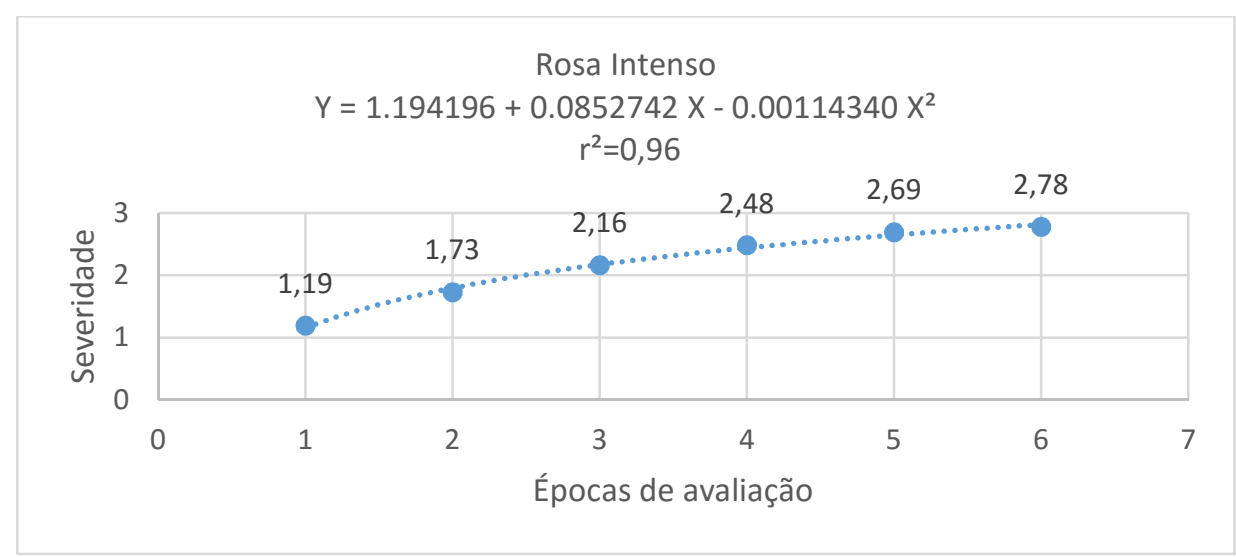

Figura 2.20 - Severidade da virose do endurecimento dos frutos (Cowpea aphid-borne mosaic virus) na progênie Rosa Intenso de maracujazeiro azedo (Passiflora edulis Sims), em 6 avaliações semanais. As curvas referem-se aos valores estimados e os pontos aos valores observados. Brasília-UnB, 2015. 
Anexo 2. Curvas de regressão dos dados coletados de Incidência e Severidade da bacteriose (Xanthomonas axonopodis pv. passiflorae) dos ensaios realizados em casa de vegetação da Estação Experimental de Biologia da Universidade de Brasília - UnB, no período de maio a julho de 2015.

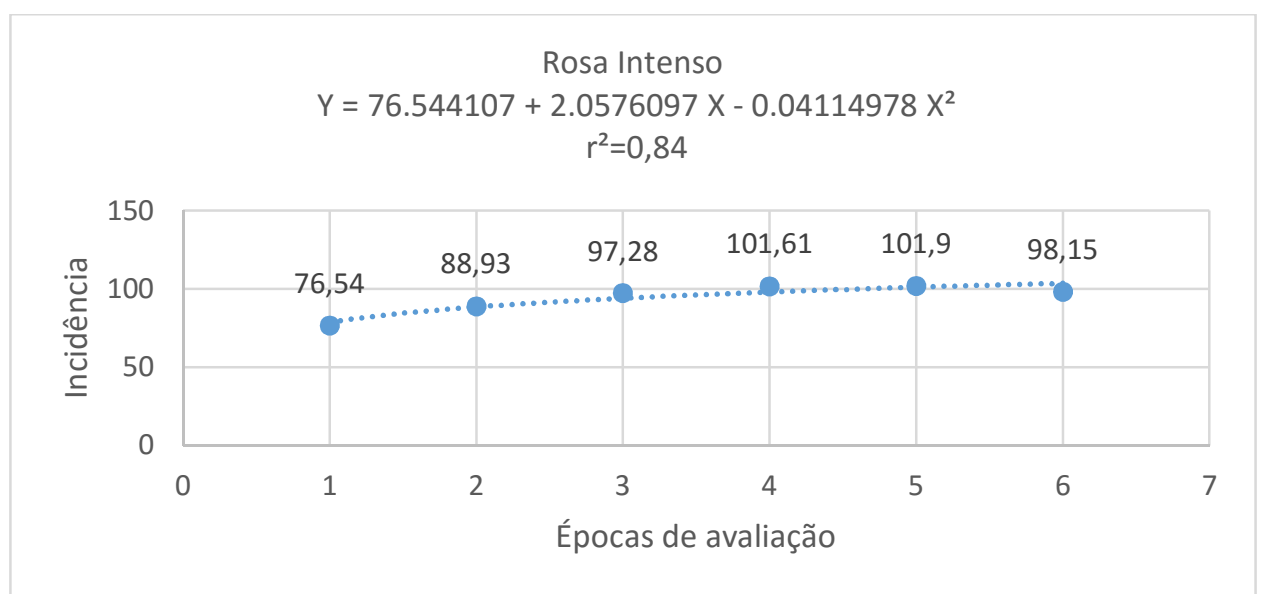

Figura 3.1 - Incidência da bacteriose (Xanthomonas axonopodis pv. passiflorae) na progênie Rosa Intenso de maracujazeiro azedo (Passiflora edulis Sims), em 6 avaliações semanais. As curvas referem-se aos valores estimados e os pontos aos valores observados. Brasília-UnB, 2015.

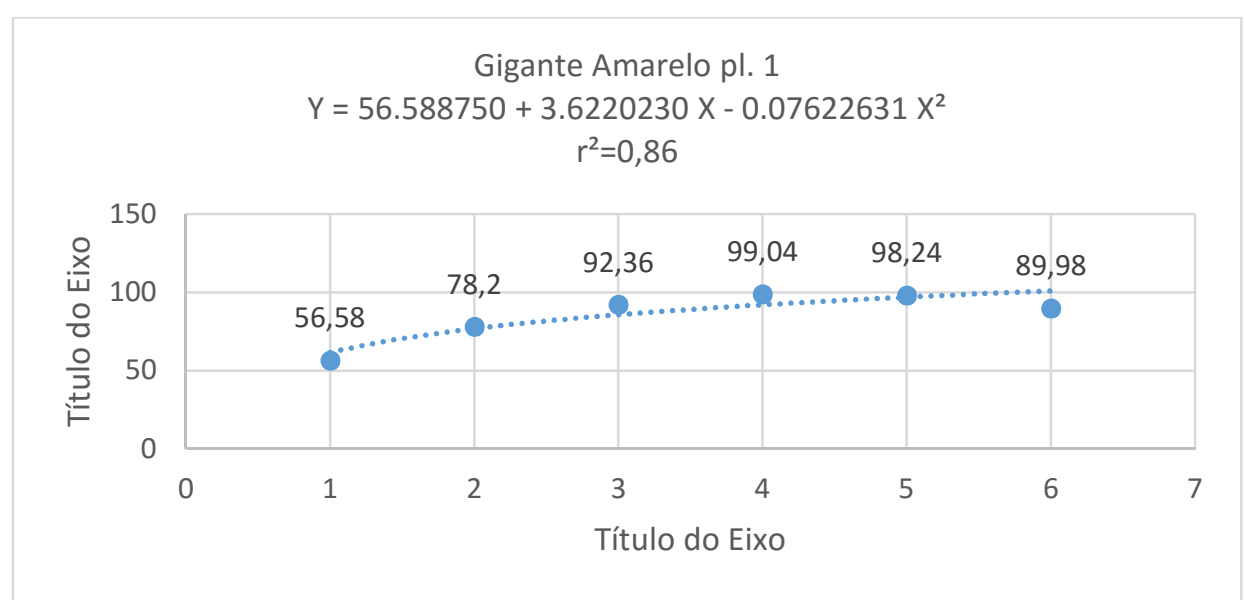

Figura 3.2 - Incidência da bacteriose (Xanthomonas axonopodis pv. passiflorae) na progênie Gigante Amarelo pl. 1 de maracujazeiro azedo (Passiflora edulis Sims), em 6 avaliações semanais. As curvas referem-se aos valores estimados e os pontos aos valores observados. Brasília-UnB, 2015. 


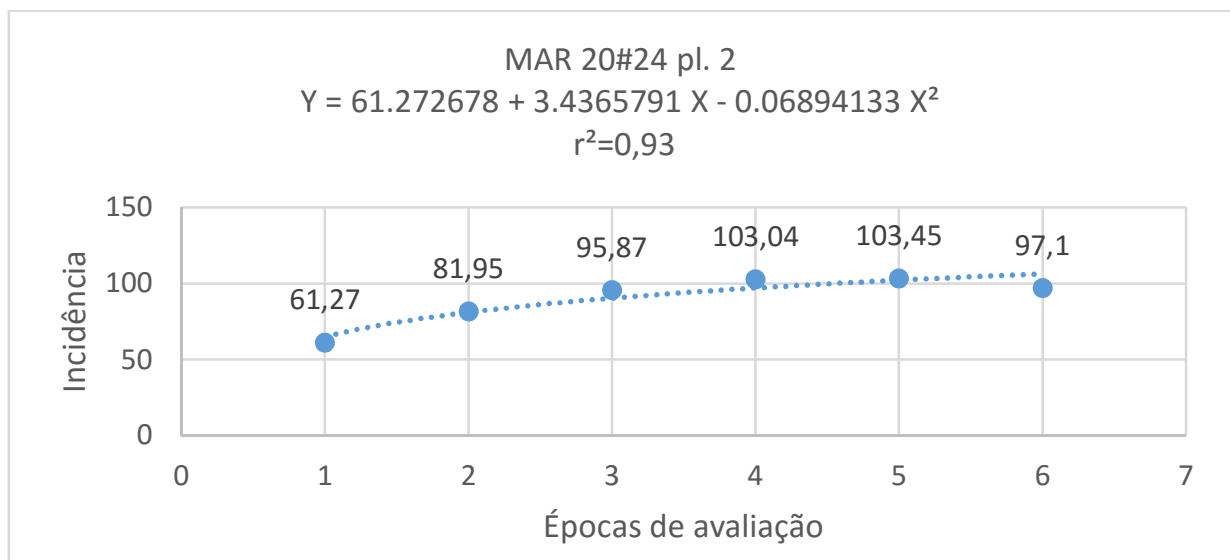

Figura 3.3 - Incidência da bacteriose (Xanthomonas axonopodis pv. passiflorae) na progênie MAR 20\#24 pl. 2 de maracujazeiro azedo (Passiflora edulis Sims), em 6 avaliações semanais. As curvas referem-se aos valores estimados e os pontos aos valores observados. Brasília-UnB, 2015.

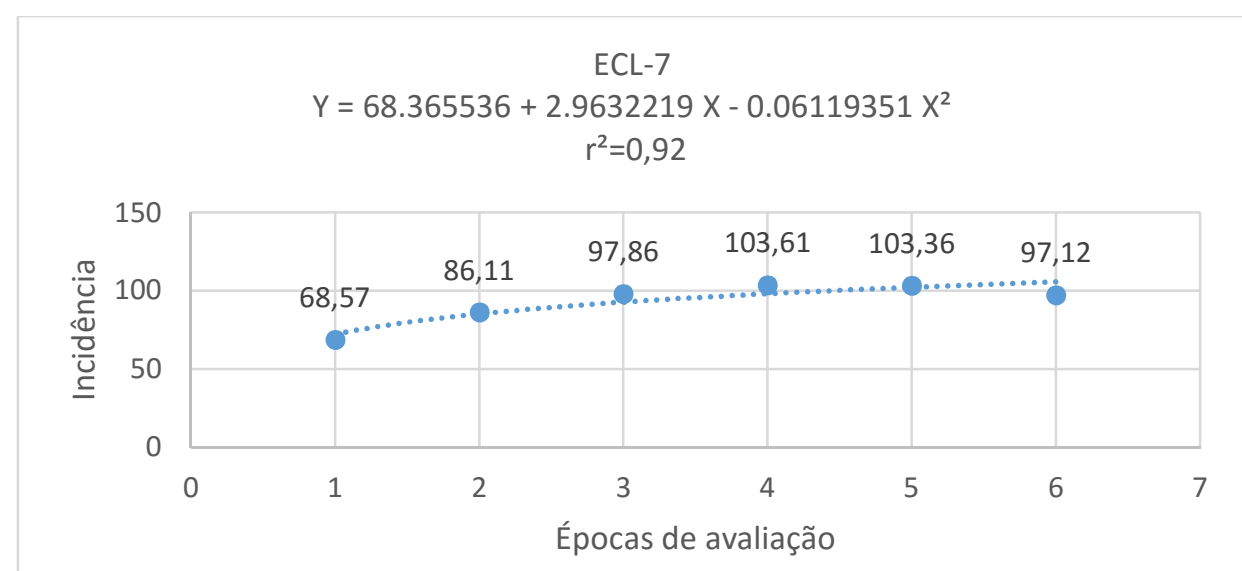

Figura 3.4 - Incidência da bacteriose (Xanthomonas axonopodis pv. passiflorae) na progênie ECL-7 de maracujazeiro azedo (Passiflora edulis Sims), em 6 avaliações semanais. As curvas referem-se aos valores estimados e os pontos aos valores observados. Brasília-UnB, 2015.

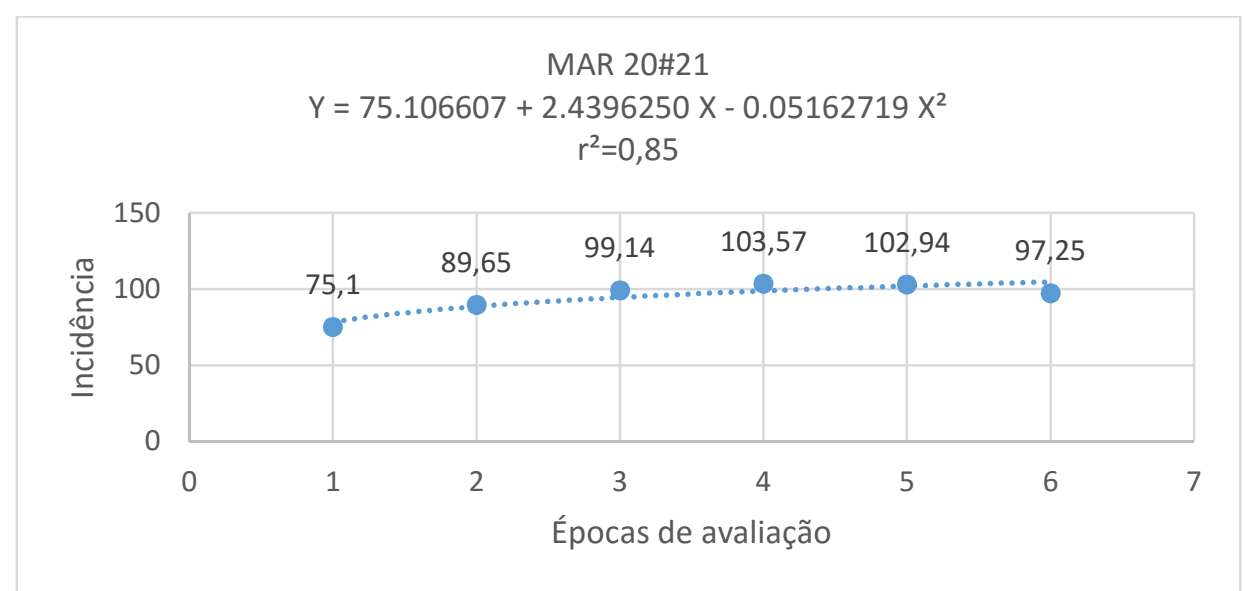

Figura 3.5 - Incidência da bacteriose (Xanthomonas axonopodis pv. passiflorae) na progênie MAR 20\#21 de maracujazeiro azedo (Passiflora edulis Sims), em 6 avaliações semanais. As curvas referem-se aos valores estimados e os pontos aos valores observados. Brasília-UnB, 2015. 


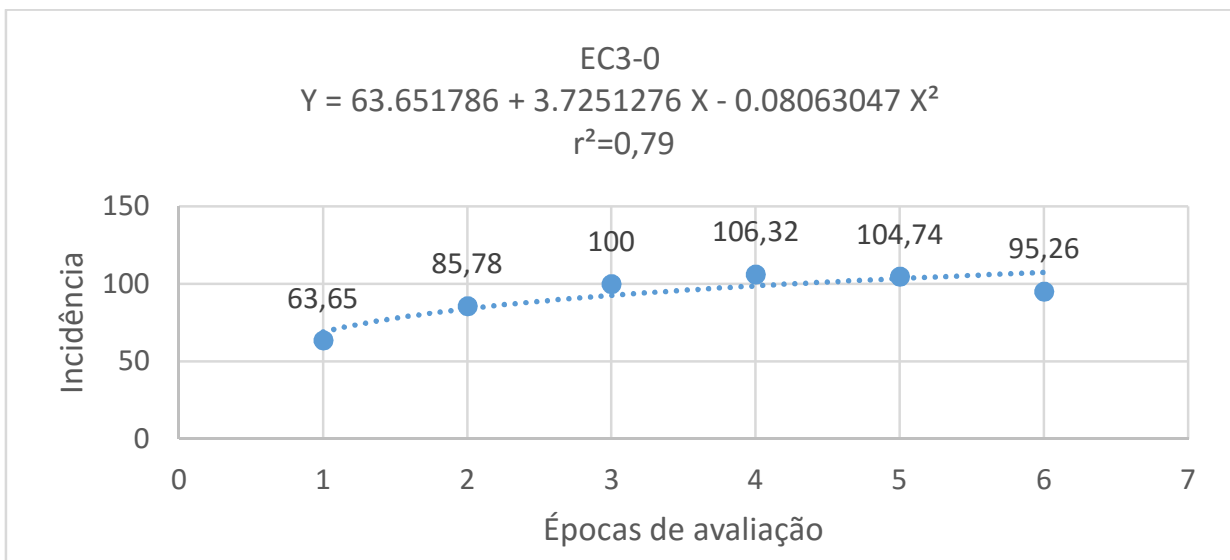

Figura 3.6 - Incidência da bacteriose (Xanthomonas axonopodis pv. passiflorae) na progênie EC3-0de maracujazeiro azedo (Passiflora edulis Sims), em 6 avaliações semanais. As curvas referem-se aos valores estimados e os pontos aos valores observados. Brasília-UnB, 2015.

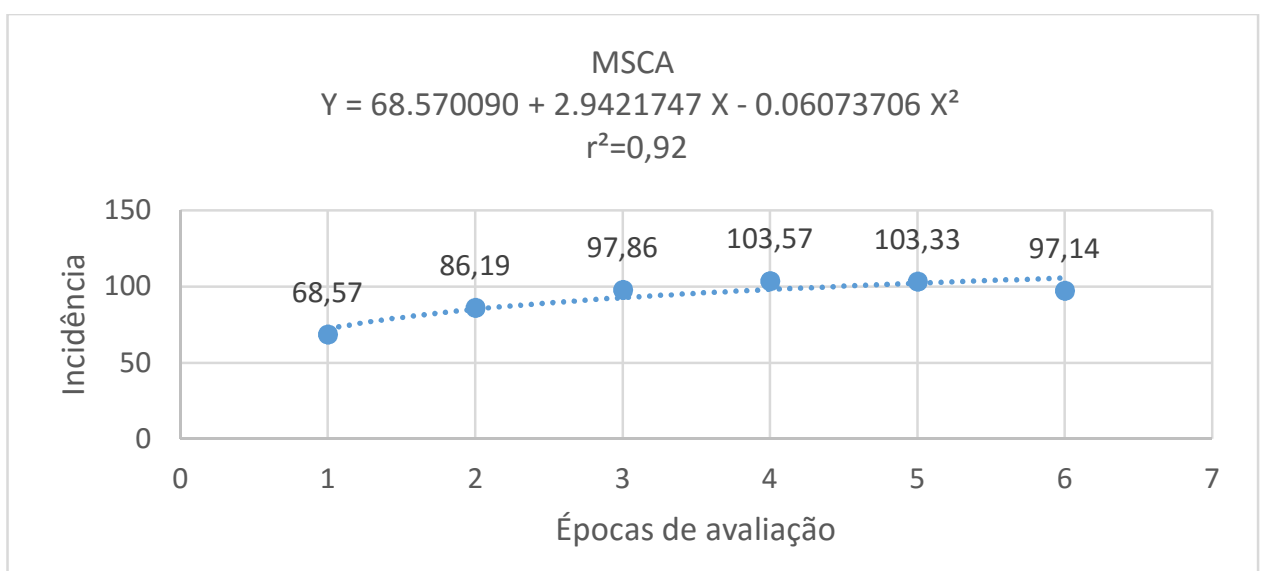

Figura 3.7 - Incidência da bacteriose (Xanthomonas axonopodis pv. passiflorae) na progênie MSCA de maracujazeiro azedo (Passiflora edulis Sims), em 6 avaliações semanais. As curvas referem-se aos valores estimados e os pontos aos valores observados. Brasília-UnB, 2015.

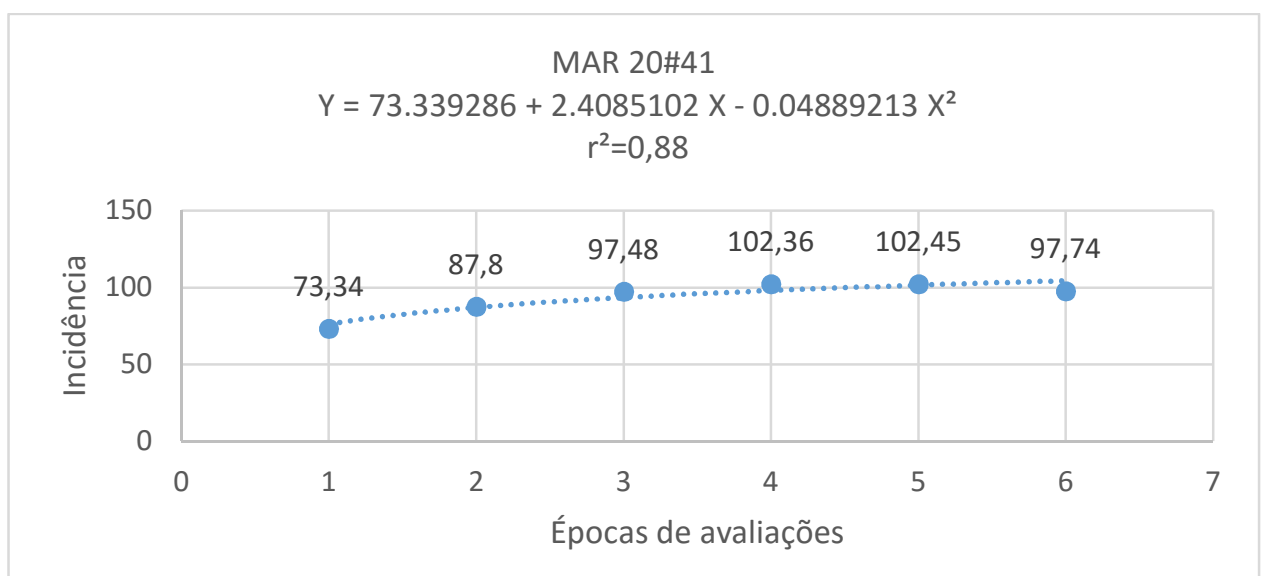

Figura 3.8 - Incidência da bacteriose (Xanthomonas axonopodis pv. passiflorae) naprogênie MAR 20\#41 de maracujazeiro azedo (Passiflora edulis Sims), em 6 avaliações semanais. As curvas referem-se aos valores estimados e os pontos aos valores observados. Brasília-UnB, 2015. 


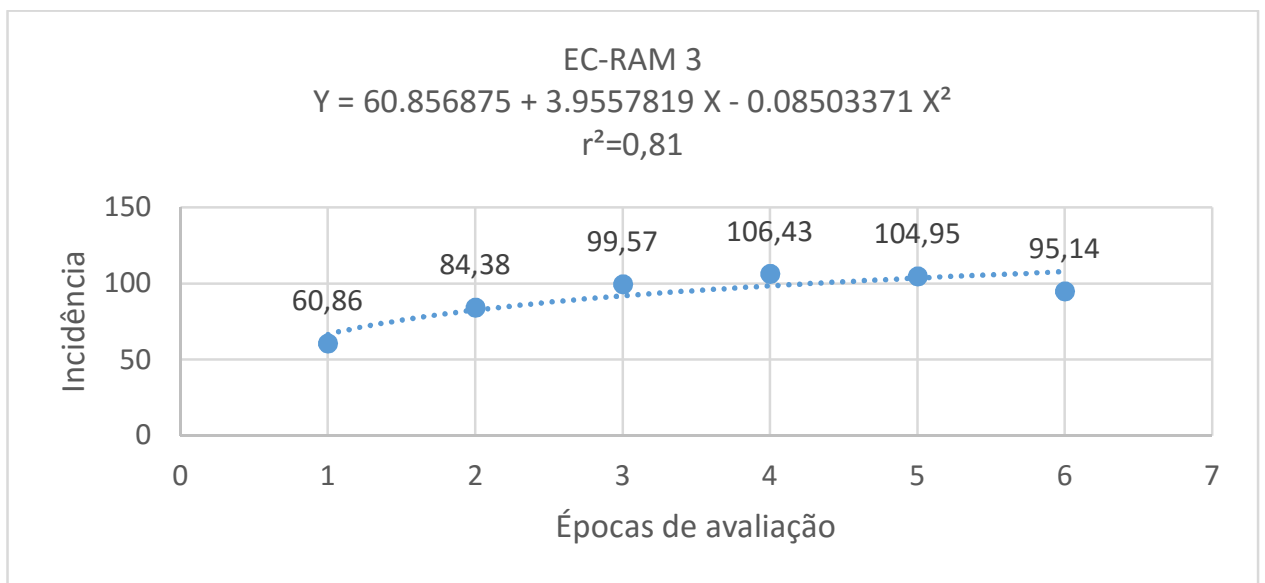

Figura 3.9 - Incidência da bacteriose (Xanthomonas axonopodis pv. passiflorae) na progênie EC-RAM 3 de maracujazeiro azedo (Passiflora edulis Sims), em 6 avaliações semanais. As curvas referem-se aos valores estimados e os pontos aos valores observados. Brasília-UnB, 2015.

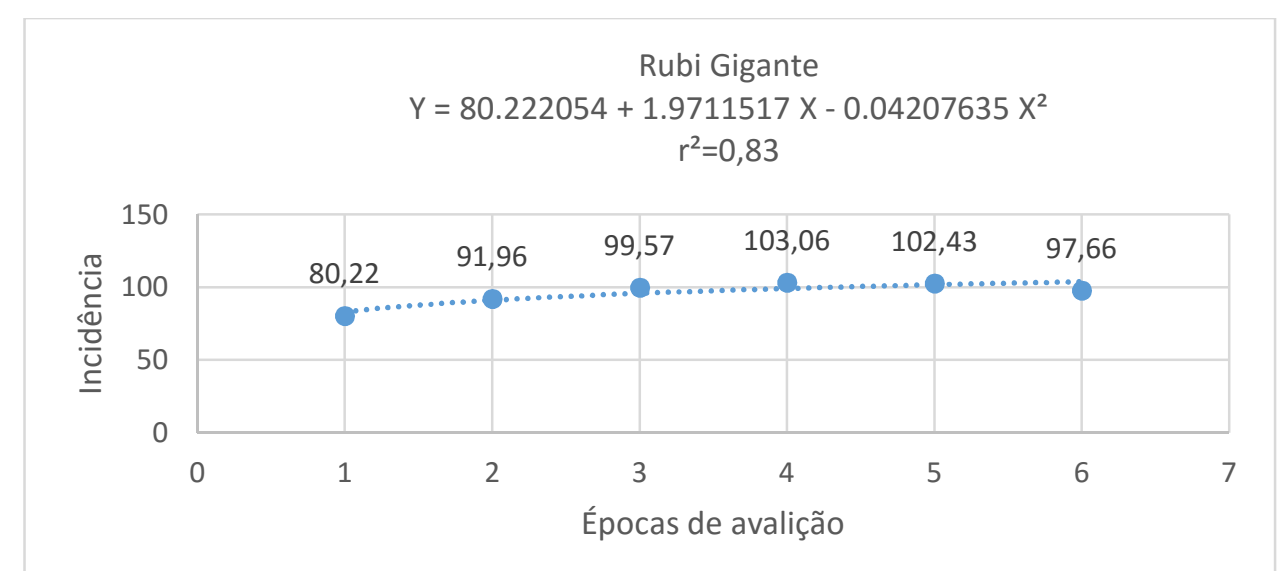

Figura 3.10 - Incidência da bacteriose (Xanthomonas axonopodis pv. passiflorae) na progênie Rubi Gigante de maracujazeiro azedo (Passiflora edulis Sims), em 6 avaliações semanais. As curvas referem-se aos valores estimados e os pontos aos valores observados. Brasília-UnB, 2015.

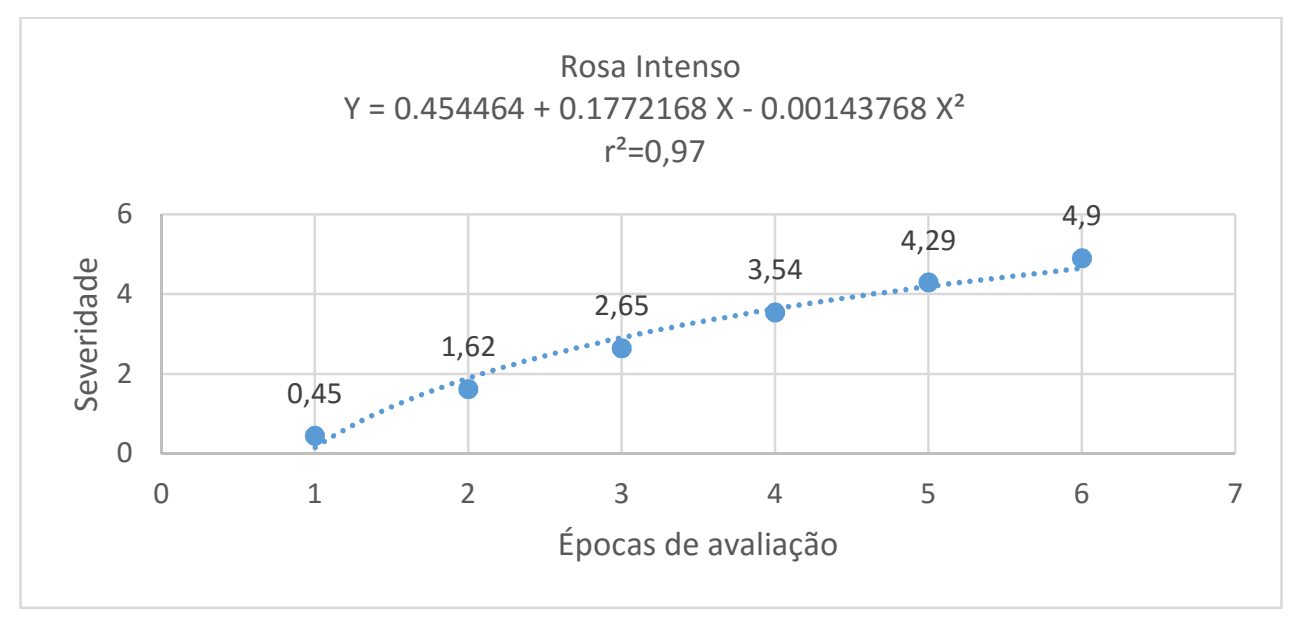

Figura 3.11 - Severidade da bacteriose (Xanthomonas axonopodis pv. passiflorae) na progênie Rosa Intenso de maracujazeiro azedo (Passiflora edulis Sims), em 6 avaliações semanais. As curvas referem-se aos valores estimados e os pontos aos valores observados. Brasília-UnB, 2015. 


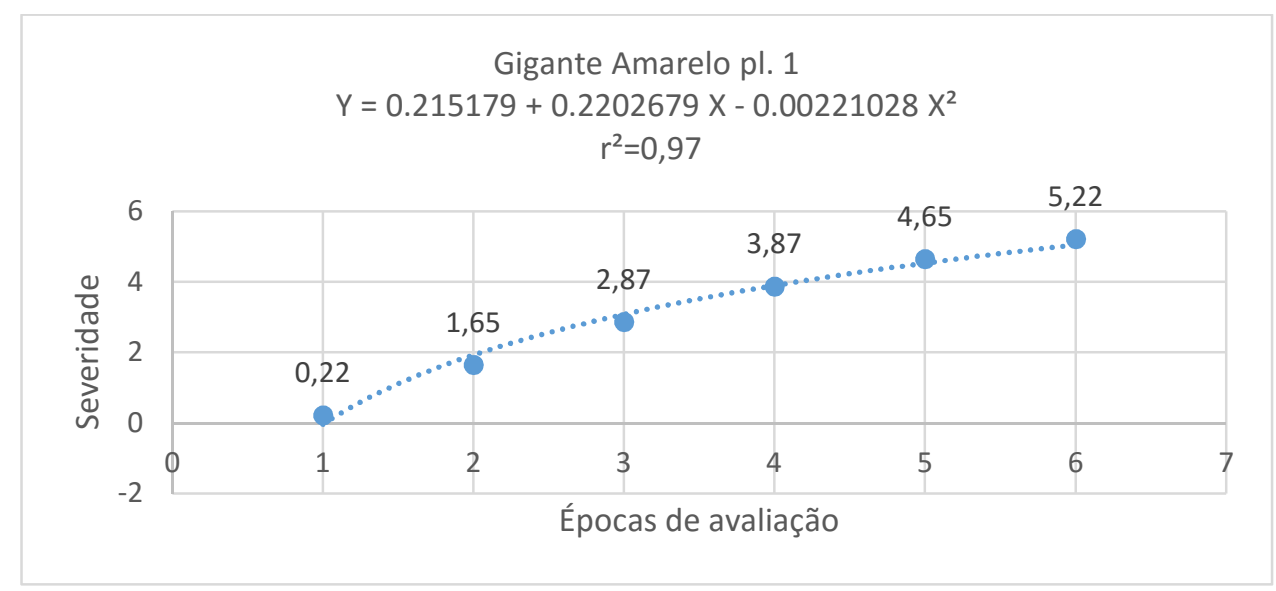

Figura 3.12 - Severidade da bacteriose (Xanthomonas axonopodis pv. passiflorae) na progênie Gigante Amarelo pl. 1 de maracujazeiro azedo (Passiflora edulis Sims), em 6 avaliações semanais. As curvas referem-se aos valores estimados e os pontos aos valores observados. Brasília-UnB, 2015.

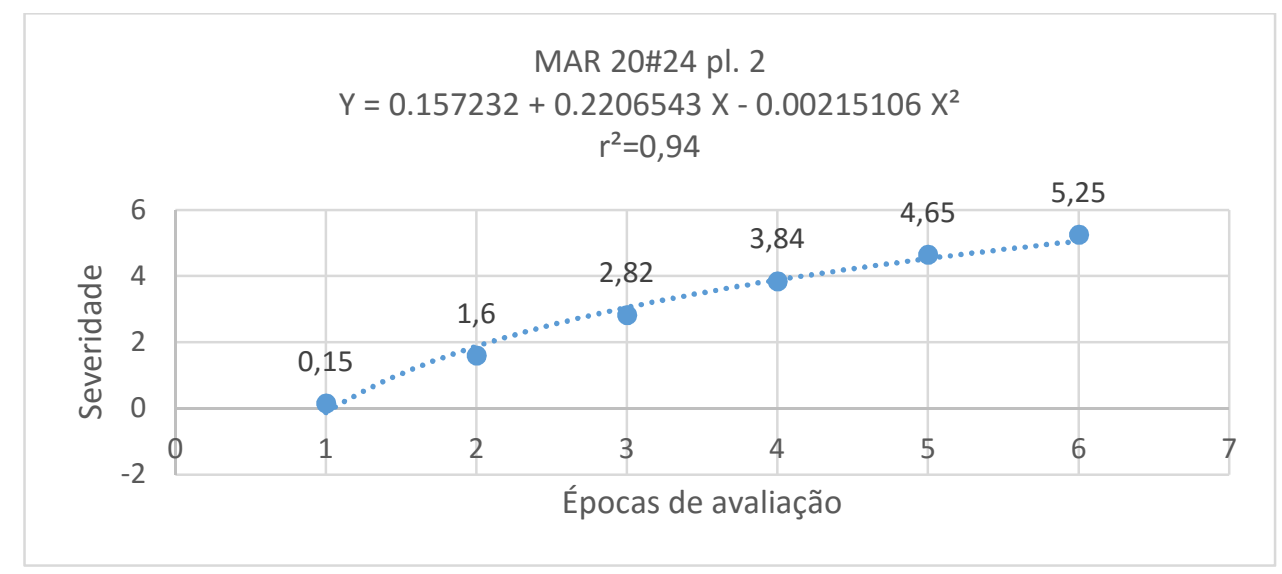

Figura 3.13 - Severidade da bacteriose (Xanthomonas axonopodis pv. passiflorae) na progênie MAR $20 \# 24$ pl. 2 de maracujazeiro azedo (Passiflora edulis Sims), em 6 avaliações semanais. As curvas referemse aos valores estimados e os pontos aos valores observados. Brasília-UnB, 2015.

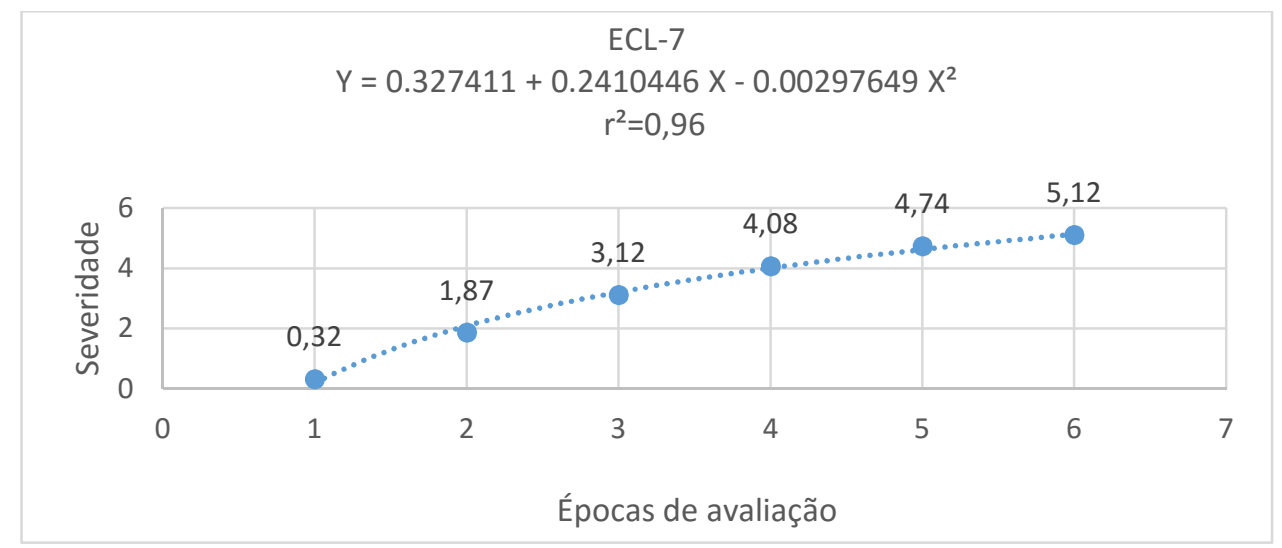

Figura 3.14 - Severidade da bacteriose (Xanthomonas axonopodis pv. passiflorae) na progênie ECL-7 de maracujazeiro azedo (Passiflora edulis Sims), em 6 avaliações semanais. As curvas referem-se aos valores estimados e os pontos aos valores observados. Brasília-UnB, 2015. 


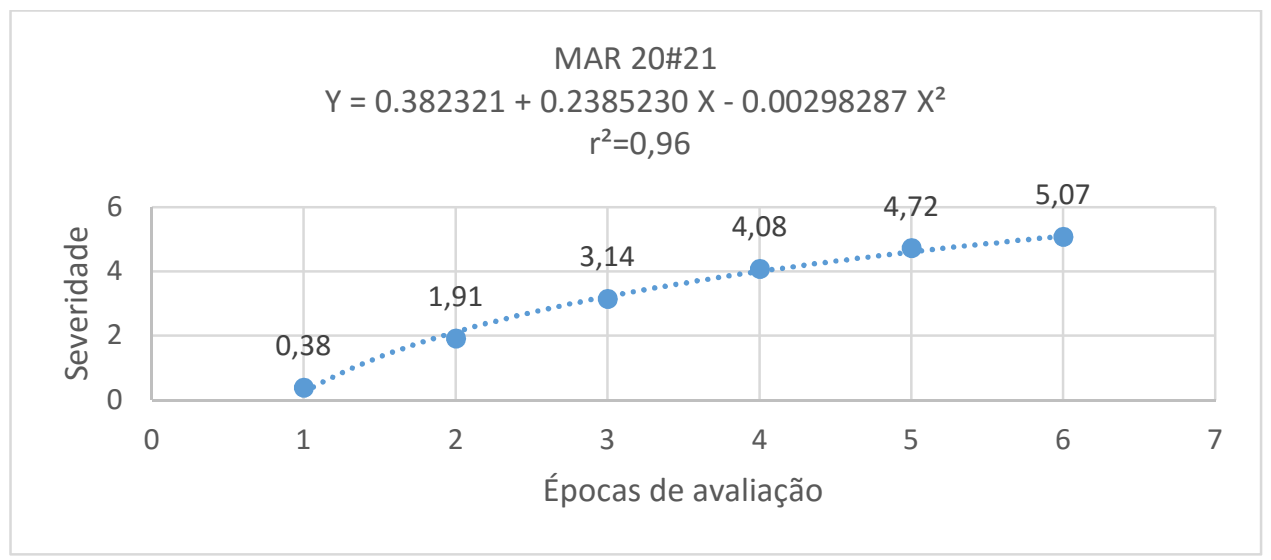

Figura 3.15 - Severidadeda bacteriose (Xanthomonas axonopodis pv. passiflorae) na progênie MAR $20 \# 21$ de maracujazeiro azedo (Passiflora edulis Sims), em 6 avaliações semanais. As curvas referem-se aos valores estimados e os pontos aos valores observados. Brasília-UnB, 2015.

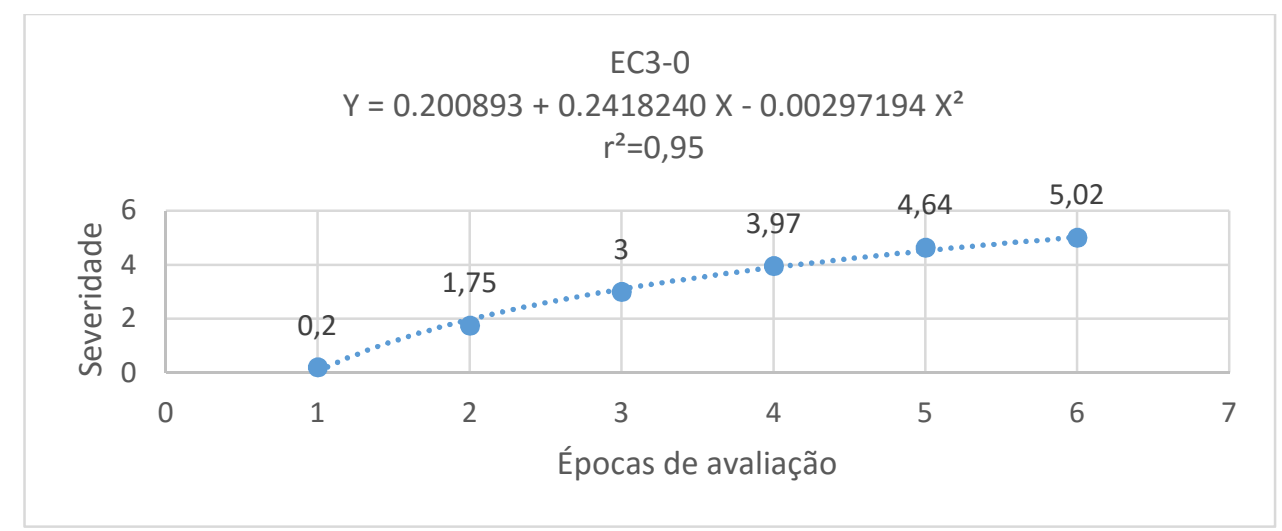

Figura 3.16 - Severidade da bacteriose (Xanthomonas axonopodis pv. passiflorae) na progênie EC3-0 de maracujazeiro azedo (Passiflora edulis Sims), em 6 avaliações semanais. As curvas referem-se aos valores estimados e os pontos aos valores observados. Brasília-UnB, 2015.

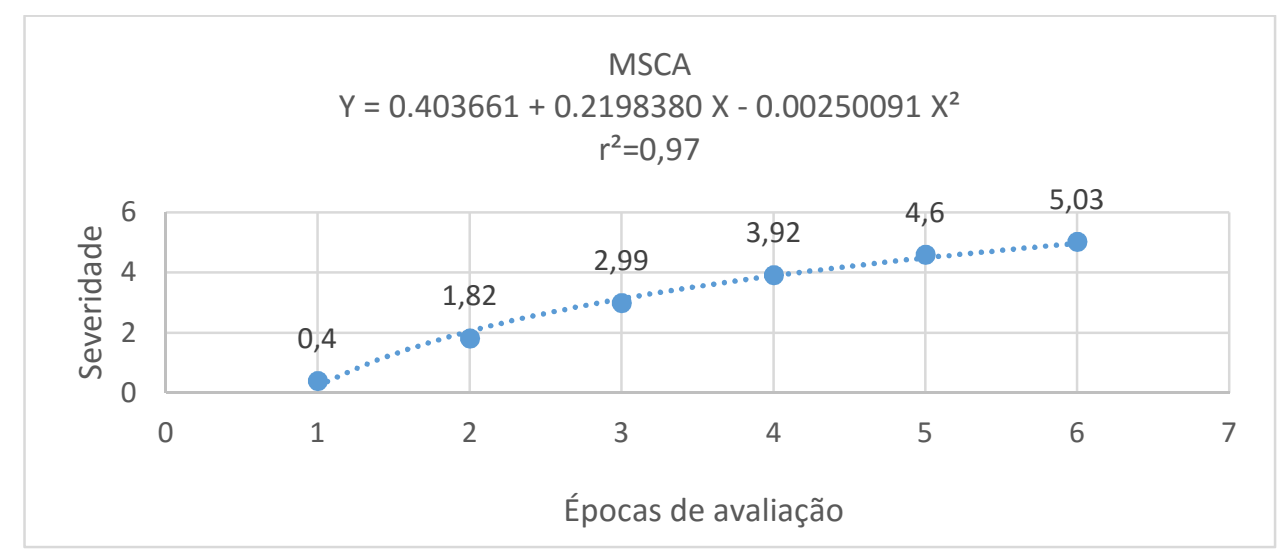

Figura 3.17 - Severidade da bacteriose (Xanthomonas axonopodis pv. passiflorae) na progênie MSCA de maracujazeiro azedo (Passiflora edulis Sims), em 6 avaliações semanais. As curvas referem-se aos valores estimados e os pontos aos valores observados. Brasília-UnB, 2015. 


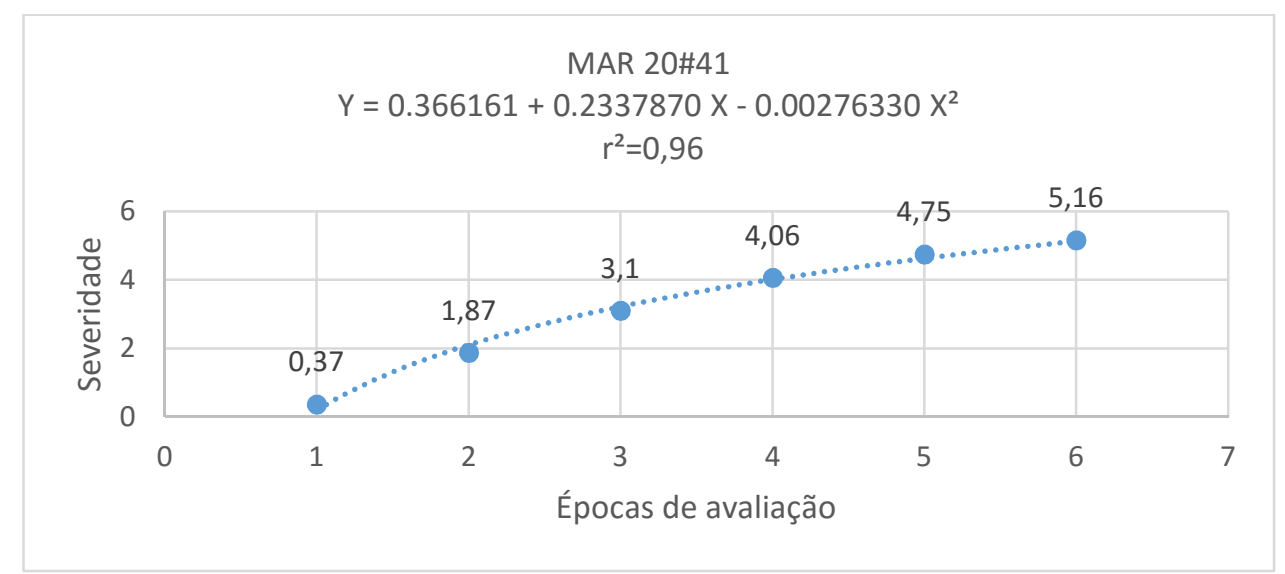

Figura 3.18 - Severidade da bacteriose (Xanthomonas axonopodis pv. passiflorae) na progênie MAR $20 \# 41$ de maracujazeiro azedo (Passiflora edulis Sims), em 6 avaliações semanais. As curvas referem-se aos valores estimados e os pontos aos valores observados. Brasília-UnB, 2015.

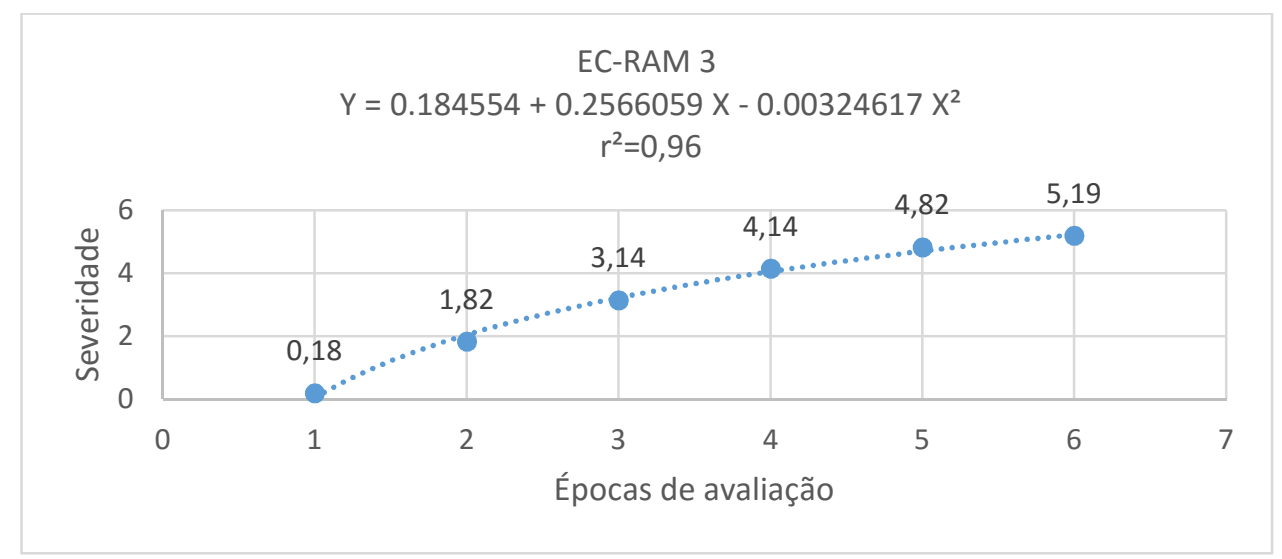

Figura 3.19 - Severidade da bacteriose (Xanthomonas axonopodis pv. passiflorae) na progênie EC-RAM 3de maracujazeiro azedo (Passiflora edulis Sims), em 6 avaliações semanais. As curvas referem-se aos valores estimados e os pontos aos valores observados. Brasília-UnB, 2015.

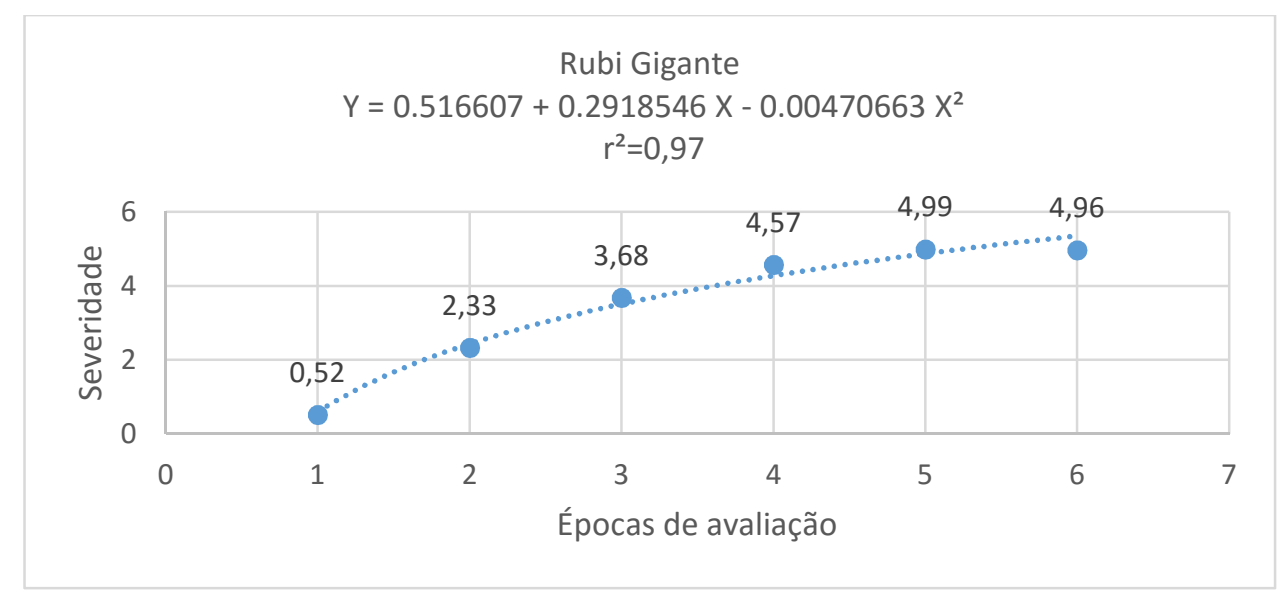

Figura 3.20 - Severidade da bacteriose (Xanthomonas axonopodis pv. passiflorae)na progênie Rubi Gigante de maracujazeiro azedo (Passiflora edulis Sims), em 6 avaliações semanais. As curvas referem-se aos valores estimados e os pontos aos valores observados. Brasília-UnB, 2015. 
Anexo 3. Fotos

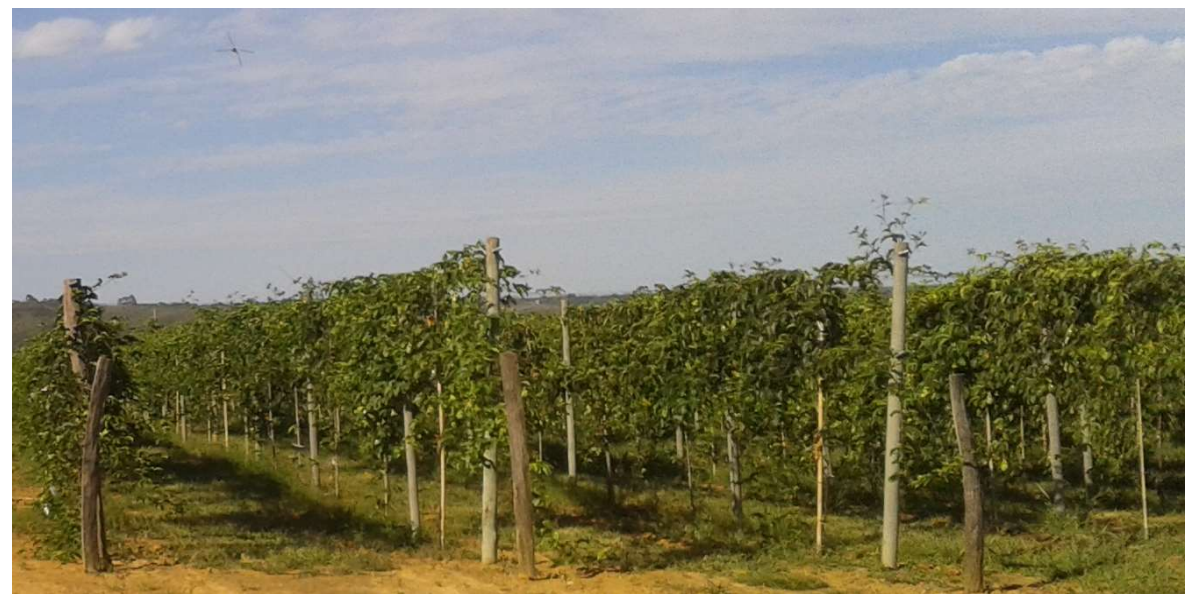

Figura 4 - Pomar de maracujazeiro azedo (Passiflora edulis Sims). Fazenda Água Limpa (FAL)-UnB, 2015.

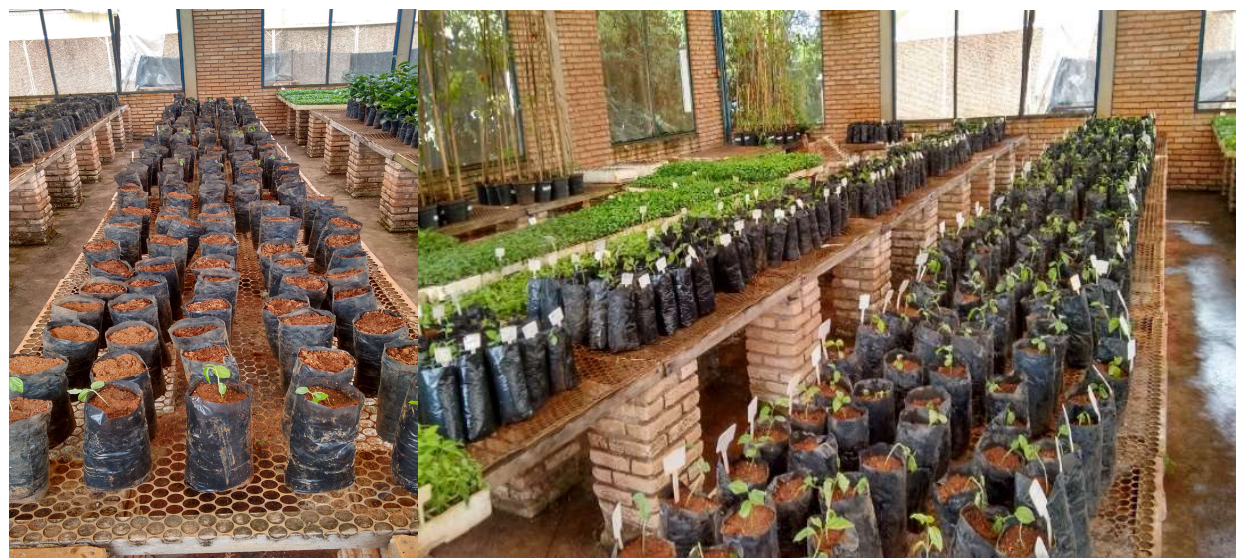

Figura 5- Preparo de mudas de maracujazeiro azedo (Passiflora edulis Sims) para inoculação. Estação Experimental de Biologia-UnB, 2015.

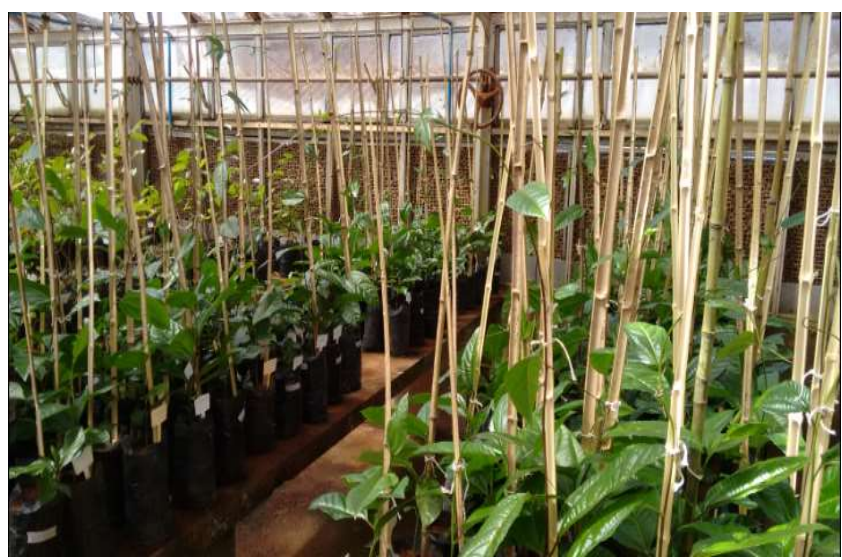

Figura 6- Mudas de maracujazeiro azedo (Passiflora edulis Sims) para inoculação. Estação Experimental de Biologia-UnB, 2015. 


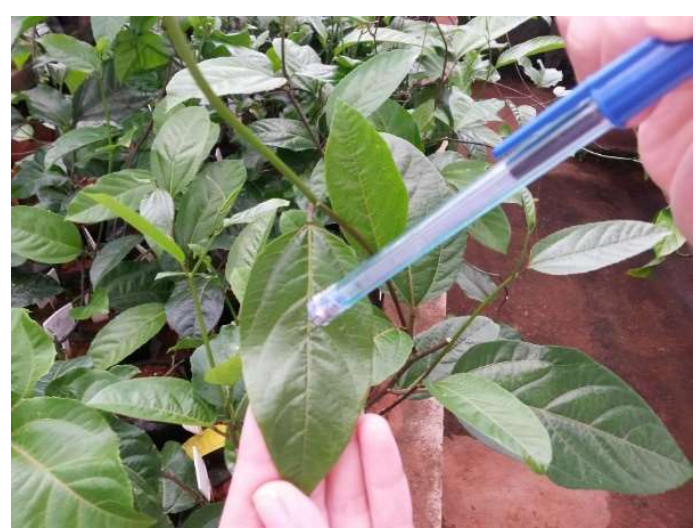

Figura 7- Inoculação de bacteriose em mudas de maracujazeiro azedo (Passiflora edulis Sims). Estação Experimental de Biologia-UnB, 2015

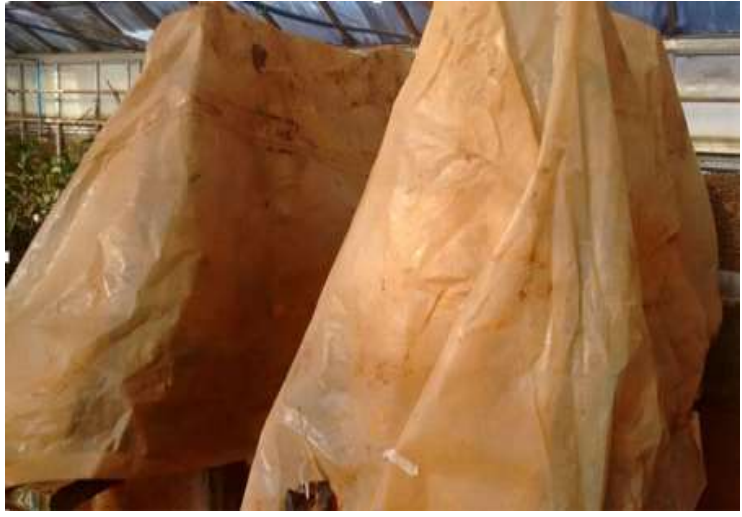

Figura 8- Câmara úmida feita após a inoculação de bacteriose em mudas de maracujazeiro azedo (Passiflora edulis Sims). Estação Experimental de Biologia-UnB, 2015.

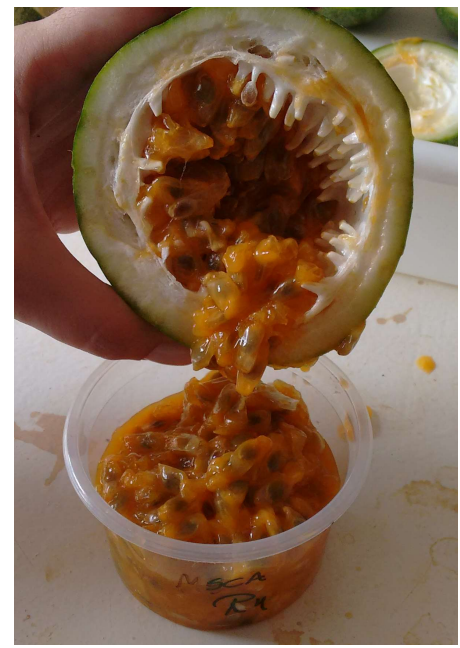

Figura 9- Retirada da polpa de frutos de maracujá azedo (Passiflora edulis Sims) para análises físicas. Estação Experimental de Biologia-UnB, 2015. 